NBER WORKING PAPER SERIES

U.S. INTERVENTION DURING THE BRETTON WOODS ERA:

1962-1973

Michael D. Bordo

Owen F. Humpage

Anna J. Schwartz

Working Paper 16946

http://www.nber.org/papers/w16946

NATIONAL BUREAU OF ECONOMIC RESEARCH

1050 Massachusetts Avenue

Cambridge, MA 02138

April 2011

The authors thank Michael Shenk, and Zebo Zakir for their research assistance. The views expressed herein are those of the authors and do not necessarily reflect the view of the National Bureau of Economic Research.

NBER working papers are circulated for discussion and comment purposes. They have not been peerreviewed or been subject to the review by the NBER Board of Directors that accompanies official NBER publications.

(C) 2011 by Michael D. Bordo, Owen F. Humpage, and Anna J. Schwartz. All rights reserved. Short sections of text, not to exceed two paragraphs, may be quoted without explicit permission provided that full credit, including (C) notice, is given to the source. 
U.S. Intervention During the Bretton Woods Era: 1962-1973

Michael D. Bordo, Owen F. Humpage, and Anna J. Schwartz

NBER Working Paper No. 16946

April 2011

JEL No. E0,N1

\begin{abstract}
$\underline{\text { ABSTRACT }}$
By the early 1960s, outstanding U.S. dollar liabilities began to exceed the U.S. gold stock, suggesting that the United States could not completely maintain its pledge to convert dollars into gold at the official price. This raised uncertainty about the Bretton Woods parity grid, and speculation seemed to grow. In response, the Federal Reserve instituted a series of swap lines to provide central banks with cover for unwanted, but temporary accumulations of dollars and to provide foreign central banks with dollar funds to finance their own interventions. The Treasury also began intervening in the market. The operations often forestalled gold losses, but in so doing, delayed the need to solve Bretton Woods' fundamental underlying problems. In addition, the institutional arrangements forged between the Federal Reserve and the U.S. Treasury raised important questions bearing on Federal Reserve independence.
\end{abstract}

Michael D. Bordo

Department of Economics

Rutgers University

New Jersey Hall

75 Hamilton Street

New Brunswick, NJ 08901

and NBER

bordo@econ.rutgers.edu

Owen F. Humpage

Federal Reserve Bank of Cleveland

P.O. Box 6387

Cleveland, $\mathrm{OH}$ 44101-1387

owen.f.humpage@clev.frb.org
Anna J. Schwartz

NBER

365 Fifth Ave, 5th Floor

New York, NY 10016

aschwartz@gc.cuny.edu 


\section{U.S. Intervention during the Bretton Woods Era: 1962-1973}

"There is little evidence...of any systematic effort by the Federal Reserve to conduct monetary policy in a manner consistent with the requirements of a fixed exchange rate system. And, there is no evidence that any of the administrations objected to this neglect."

Allan H. Meltzer 1991, p. 55

\section{Introduction}

The Bretton Woods system became fully functional after 1958 when the leading developed countries made their currencies convertible for current-account transactions. At roughly the same time, however, fundamental flaws in the arrangement began to appear. The U.S. balance of payments was deteriorating markedly, undermining the U.S. commitment to maintain its official gold price. By 1961, total external U.S. dollar liabilities exceeded the U.S. gold stock, which encouraged foreign central banks to convert unwanted dollars into gold, heightened uncertainty about the entire currency grid, and fostered speculative flows.

In an attempt to neutralize speculative activity, the U.S. Treasury began intervening in the foreign exchange market in March 1961, after a 30 year hiatus. A year later, the Federal Reserve began intervening for its own account with a primary focus on providing foreign central banks with temporary cover for their unwanted dollar exposures.

These operations were stop-gap. In the early 1960s, U.S. administrations believed that much of the pressure on the balance of payments was transitional and largely related to the postwar global recovery, so finding a mechanism to buy time for an inevitable adjustment seemed appropriate. By the late 1960s, however, Bretton Woods' severe structural problems, which a rising U.S. inflation rate severely aggravated, were apparent. The maintenance of Bretton Woods required elected officials in the United States and abroad to sacrifice domestic economic goals for international objectives, a trade-off they would not make. The U.S. closed its gold window in August 1971, and generalized floating commenced in March 1973.

As a delaying tactic, U.S. foreign exchange operations were often successful. They raised the potential costs of speculation and provided cover for unwanted, temporary, and ultimately reversible dollar flows. They delayed the drain of the U.S. gold stock. But to the extent that these devises substituted for more fundamental and necessary adjustments and postponed the inevitable collapse of Bretton Woods, they were a failure. In addition, the institutional arrangement underlying U.S. intervention operations raised important, long-lasting issues about Federal Reserve independence.

This chapter explores the events that shaped the decisions to intervene, describes the mechanisms that the United States established for that purpose, and chronicles the origins of controversies, which some 30 years later, would end the operations.

\section{Bretton Woods: Prospects and Problems}

The officials who signed the International Monetary Fund (IMF) Articles of Agreement at Bretton Woods, New Hampshire, in July 1944 envisioned an international financial system based on close cooperation, which would foster stability, promote full employment, and prevent a return to the beggar-thy-neighbor policies of the early 1930 s. $^{1}$ Under the agreement, the United 
States pegged the dollar to gold at \$35 per ounce and pledged to buy and sell the metal freely at this price. Other nations established parities for their currencies relative to the dollar and were obliged to keep their exchange rates within a 1 percent band around the central value through foreign-exchange interventions, restraints on financial flows, and presumably the eventual adoption of compatible monetary policies. When faced with a transitory balance-of-payments problem, a country with insufficient reserves to finance its intervention could borrow from the IMF instead of quickly instituting deflationary macroeconomic programs. The ability to borrow reserves would also lessen the deficit country's incentive to impose trade restraints or exchange controls on current-account transactions. ${ }^{2}$

Exchange rates were not immutable under the Bretton Woods system. After IMF consultation and approval, countries facing a "fundamental disequilibrium" in their balance of payments could adjust their parities. In principle, the IMF could also insist that the country adopt macroeconomic policies consistent with any exchange-rate realignment, but the IMF lacked a credible enforcement mechanism. Deficit countries, which felt pressures to adjust more immediately than surplus countries, postponed devaluation to avoid the stigma—one of "failed economic policies"- that devaluation carried.

Although the Bretton Woods system began operating in 1946, European currencies remained inconvertible for current-account transactions until late 1958, and the Japanese yen stayed similarly inconvertible until 1964. Initially, these war-ravaged countries maintained inconvertible currencies as a means of limiting their persistent current-account deficits. Most lacked sufficient international reserves to sustain growing deficits for long, even after allowing for IMF credits. In 1949, the situation compelled many European countries to devalue their currencies relative to the dollar. France devalued in 1957 and again as late as 1959.

During the 1950s, however, the international position of the war-torn industrialized countries greatly improved. Foreign productivity and competitiveness recovered. Government grants and long-term financial outflows from the United States created persistent U.S. balanceof-payments deficits that provided a source of international reserves to accommodate expanding international trade. A general quota increase in 1959 also augmented IMF funds that were available for temporary balance-of-payments assistance. Consequently, by the late 1950s, more than a decade after its beginning, the Bretton Woods exchange-rate system became functional.

At about the same time, however, markets and central banks were quickly losing confidence in the viability of the official dollar gold price, the keystone of the entire Bretton Woods structure. Two interrelated developments proved particularly corrosive: Triffin's paradox, which describes a congenital defect in gold-reserve standards like Bretton Woods, and an accelerating U.S. inflation rate after 1965. A third factor, which acquired importance largely in conjunction with the previous two, stemmed from inevitable cross-rate adjustment problems among participating countries, other than the United States. We describe each of these factors in turn below.

\section{Triffin's Paradox}

The framers of Bretton Woods set the official price of gold at \$35 per ounce, the same price that the U.S. Gold Reserve Act of 1934 had established. Because of inflation during World War II and shortly thereafter, this official price became too low in real terms to induce sufficient gold production for expanding reserve needs (see Bordo 1993, James 1996, and Meltzer 1991). By the early 1950s, the real price of gold was only half of its 1934 value (see figure 1). ${ }^{3}$ 
Between 1948 and 1958, the free world's gold stock increased only 16\% while its imports rose 68\% (Triffin, 1960, table 14, pp. 72-3).

The United States, as noted, provided needed liquidity by running persistent balance-ofpayments deficits. Between 1950 and 1957, these deficits averaged \$1.3 billion per year, as government grants, private remittances, and long-term financial outflows typically exceeded surpluses elsewhere in the accounts (figure 2). ${ }^{4}$ Neither the United States nor the international financial community seemed to view these deficits with much concern because they stemmed from postwar redevelopment efforts and from the provision of military security. Without the international reserves that these deficits provided, the postwar recovery of global trade and world economic activity would have proceeded more slowly, because countries facing even temporary balance-of-payments deficits would quickly need to deflate, devalue, or impose disruptive trade and financial restraints.

By the early 1960s, however, the total external dollar liabilities associated with the persistent U.S. balance-of-payments deficits began to exceed the U.S. gold stock, implying that the United States could not completely fulfill its obligation to sell gold at the official price (see figure 3). ${ }^{5}$ The very act of providing needed liquidity was itself creating uncertainty about the long-term viability of the parity structure. This was Triffin's paradox (Triffin 1957, 1960). At the time, however, few interpreted the situation as necessarily leading to the demise of the Bretton Woods system. ${ }^{6}$

An outflow of gold accompanied the U.S. balance-of-payments deficits during the 1950s, but it seemed a reasonable reversal of the substantial-largely safe-haven-gold acquisitions that the United States experienced in the 1930s and 1940s. The United States, which held 60 percent of the world's gold reserves in 1950, lost only $\$ 213$ million worth of gold on average each year between 1950 and 1957 (figure 4). ${ }^{7}$ During that time, foreign countries increased their gold reserves mainly out of free-world gold production and through small purchases from the Soviet Union. In addition, the IMF sold the United States \$800 million worth of gold between 1951 and 1957 (Board of Governors, 1963, p. 422).

Between 1958 and 1960, however, U.S. balance-of-payments deficits widened to \$3.7 billion per year on average as surpluses on U.S. goods and services trade narrowed slightly and as long-term financial outflows increased sharply. The most disturbing aspect of the expanding U.S. balance-of-payments deficits, however, occurred with respect to short-term financial flows beginning in 1960. Heretofore, the United States had typically experienced small short-term financial inflows (including unrecorded items), but in 1960 the country witnessed a large outflow of nearly $\$ 2.5$ billion. Although U.S. balance-of-payments deficits narrowed somewhat in 1961 and 1962, substantial outflows of short-term financial capital, often motivated by exchange-rate concerns, generally persisted.

Between 1958 and 1962, the average U.S. gold loss increased six-fold to nearly $\$ 1.4$ billion per year. The U.S. gold stock declined by $\$ 6.8$ billion or $30 \%$ as foreign countries converted dollar reserves into gold. ${ }^{8}$ The heavy gold losses would not have been so disturbing to U.S. policy makers if they had not been accompanied by evidence of a run on the dollar. Foreign monetary authorities were not only converting new acquisitions of dollars into gold, but they were also converting - or planning to convert—a substantial portion of their existing dollar balances (FOMC, Minutes, 10 January 1961, p.10). 
Between 1957 and 1962, the proportion of international reserves held in gold by nonCommunist countries increased from 45 percent to 49 percent (Board of Governors, 1963, p. 423). European countries, particularly France, Italy, and Germany, accounted for almost all of this gain; most other countries kept the share of their gold reserves fairly constant (Board of Governors, 1963, p.424). Despite the accelerated gold losses, the United States still held \$16 billion worth of gold reserves in 1962, approximately two-fifths of the world's gold stock. ${ }^{9}$

On 20 October 1960, the price of gold on the London market shot above the official U.S. gold price to $\$ 40$ per ounce, as private demand for gold reached record levels. This was a turning point in the Bretton Woods era. Henceforth, as we will document, both gold and foreignexchange markets would remain vulnerable to speculative pressures consistent with Triffin's paradox.

\section{U.S. Inflation after 1965}

In the early 1960s, the Bretton Woods system constrained Federal Reserve behavior and anchored inflation expectations (see Bordo and Eichengreen 2008). Policymakers understood that inflation could lead to a deterioration in the U.S. balance of payments and to a reduction in the U.S. gold stock, which eventually could undermine the official gold price. Between 1959 and 1965, inflation averaged just 11/4 percent in the United States. The Bretton Woods constraint did not matter prior to 1958 because of the global dollar-reserve shortage, and to be sure, U.S. monetary policy was not exclusively focused on the official gold price during the early 1960s. The System responded to inflation and business-cycle developments. Still, all else constant, Bretton Woods led to more monetary restrain or less ease than otherwise would have been the case. The record of dissents within the FOMC reflects this inclination (Bordo and Eichengreen 2008, table 1). Between 1961 and 1966, balance-of-payments considerations prompted most of these dissents, and they almost always went in favor of a tighter monetary-policy stance.

In the early 1960s, as we will document, the U.S. Treasury took on greater responsibility for balance-of-payments developments and instituted a number of mechanisms, including foreign-exchange intervention, the Gold Pool, and the interest equalization tax to address emerging international concerns (Bordo and Eichengreen 2008). This shift in responsibility and the development of these mechanisms loosened the Bretton Woods constraint on Federal Reserve policy. Between 1965 and 1971, balance-of-payment considerations still arose within the FOMC, and during crisis periods, such as the devaluation of the British pound in 1968, they directly shaped policy, but overall, the Treasury's balance-of-payments activism allowed the FOMC to focus on domestic inflation and business-cycle developments.

The inflation that ensued helped end the Bretton Woods system. Inflation in the United States rose from less than 2 percent in late 1965 to around 6 percent by late 1970. It moderated somewhat after 1970, but remained above 4 percent through August 1971, when President Nixon closed the gold window, and inflation stayed between 3 and 4 percent prior to March 1973, when generalized floating began. In the intervening years, as foreign countries defended their pegs, they imported U.S. inflation. As inflation aggravated Triffin's paradox, the dollar shortage became a dollar glut, and the parity grid eventually collapsed in early 1973.

While the weakening of the Bretton Woods constraint surely gave the Federal Reserve greater latitude to pursue domestic economic objectives, it does not explain why over the next 15 years, the System, nevertheless, failed to pursue price stability. ${ }^{10}$ Other factors came into play. With the Kennedy administration, policy makers and many academic economists adopted an 
economic framework that de-emphasized the role of money in the inflation process (see Hetzel 2008 and Meltzer 2009a). In addition, these economists generally saw unemployment as a more serious social problem than inflation and, at least prior to 1970, were willing to accept higher inflation in hopes of a permanently lower unemployment rate. They no longer saw inflation as eventually producing higher unemployment, as they had during the 1950s (Romer and Romer 2002). They emphasized keeping economic activity on its potential or full-employment path, where inflation by definition could not be a problem. Economists read any aggregate price pressures that existed when the economy fell away from potential, as stemming from structural or uncompetitive elements in the economy. Such price pressures were only responsive to direct controls or incomes policies. Among its many flaws, such a model required that policymakers adequately measure potential, which was not the case. In addition, the management of aggregate demand - to keep it expanding at potential—emphasized fiscal actions, especially prior to the early 1970s. Monetary policy was to support fiscal policy; it did not focus on price stability.

The ancillary role of monetary policy made it susceptible to political pressures, especially in the face of a weakened Bretton Woods constraint. Meltzer (2005) argues that the Federal Reserve System facilitated inflation for three-largely political—reasons: First, Chairman William McChesney Martin consistently delayed the System's response to evidence of rising inflation because he sought consensus with the administration-and, for that matter, among FOMC participants - about the need for such policy actions. This typically meant delaying a response until the costs of inaction became abundantly clear. Second, as suggested above, Martin and most members of the FOMC did not believe that monetary policy was solely responsible for inflation. With the FOMC meeting on a three-week cycle, members' perspectives were instead typically short-term, often ad hoc, and often inconsistent. FOMC directions to the open-market Desk were often vague with the consequence that the Manager focused on short-term market conditions (Meltzer 2005, p. 155). Third, Martin's concept of independence implied that the Federal Reserve needed to cooperate as much as possible with the administration to fulfill the goals of the Employment Act of 1946. He viewed the Federal Reserve System as independent within the government, not independent of the government. Accordingly, the System should not frustrate the attainment of administration policy objectives or raise the costs of financing a budget deficit, if at all possible. The System, for example, regularly helped facilitate the issuance of Treasury securities by supplying enough reserves to peg interest rate around the time of a Treasury financing, usually about two to four weeks. Martin's view of independence contributed to his desire for consensus and his hope for nonmonetary (that is, administration) solutions to the mounting inflation and balance-of-payments problems.

\section{Cross-Rate Adjustment Problems}

A third shortcoming of the Bretton Woods system arose because cross exchange rates could not quickly adjust to balance-of-payments disequilibria. When both German and the United Kingdom pegged to the dollar, the mark-pound cross rate was also fixed. Although cross-rate-adjustment problems arose from economic developments within specific foreign countries and not directly from persistent U.S. balance-of-payments deficits, they contributed to the dollar's difficulties because they aggravated Triffin's paradox. They did so because the U.S. dollar was the key international reserve and vehicle currency, deficit countries defended their pegs by selling dollars, while surplus countries defended their pegs by buying dollars. Financial funds flowed from deficit countries to surplus countries through dollars, adding to the large, 
often unwanted dollar positions of surplus countries and creating inflationary pressures in these countries. Speculators (or their banks) fearing a pound devaluation, for example, would first sell pounds for dollars and then dollars for a strong currency, like the Swiss franc or German mark. Dollars, not pounds, flowed into these countries. Many surplus countries, like Switzerland, strictly limited the ratio of dollar reserves to gold reserves in their portfolios and would sell unwanted dollars to the United States. Cross-rate-adjustment problem, notably among the United Kingdom, Germany, and France created uncertainty about the entire Bretton Woods parity structure, as we illustrate below.

\section{The Policy Dilemma ${ }^{11}$}

If the emerging U.S. balance-of-payments problems were indeed evidence of a fundamental disequilibrium, the United States had to undertake a real dollar depreciation. Hemmed in by the perception of persistently weak domestic demand, constrained by the dollar's unique role in the Bretton Woods system, and still uncertain about the true underlying nature of recent balance-of-payments developments, none of the standard methods for achieving a real dollar depreciation seemed viable or even appropriate to U.S. policy makers. Instead, policy makers in the early 1960s opted for a number of stop-gap policies, of which exchange-market intervention became the most enduring.

The Eisenhower and Kennedy administrations attributed the worsening U.S. balance-ofpayments position between 1957 and 1962, by and large, to transitory factors stemming from U.S. military and economic aid commitments, recent cyclical developments, and the reemergence of Western Europe and Japan as global competitors. In response to these developments, the United States undertook a series of policy initiatives to hasten adjustment in the U.S. trade and long-term financial accounts and to improve the operation of the international financial system. These initiatives, however, were not those of policy makers who interpreted the current situation as critical or enduring.

U.S. policy makers also appreciated that with the maturation of the Bretton Woods system-economic recovery abroad, growing currency convertibility, and an adequate pool of liquidity-short-term financial flows could henceforth be more sensitive to international interestrate differentials and exchange-rate uncertainty. They seemed to believe, however, that once the transitory adjustments to the U.S. trade and long-term financial accounts were complete, credibility in the dollar would strengthen. After all, reserve gains in France and Italy since 1957 illustrated how quickly countries' international positions could change (Board of Governors, 1963, pp. 421 - 428). Renewed credibility in the dollar would lessen the problem of short-term financial flows.

Even if U.S. policy makers had fleetingly glimpsed emerging events as evidence that the U.S. balance-of-payments position was fundamentally unsustainable, they were unwilling to make the appropriate policy adjustments in the early 1960s. A fundamental disequilibrium would imply that the dollar was overvalued on a real basis and that a real depreciation was necessary to restore equilibrium to the U.S. balance of payments. The United States could achieve a real depreciation only through a nominal dollar devaluation, a deflation in the United States, an inflation in the rest of the world, a general revaluation of foreign currencies, or some combination of all four. Whereas U.S. policy makers might have welcomed a higher rate of inflation abroad, and whereas they actively encouraged the revaluation of currencies in surplus 
countries, they were unwilling to alter the official gold price or to dampen aggregate demand in the United States for balance-of-payments purposes. ${ }^{12}$

A one-time nominal dollar devaluation was simply out of the question. By imposing wealth losses on central banks and individuals that held open positions in U.S. dollars, any dollar devaluation could forever threaten the reserve-currency status of the U.S. dollar. Moreover, short-term financial outflows might actually increase if a one-time devaluation proved insufficient for balance-of-payments adjustment, or if other countries simultaneously devalued their currencies against the dollar. The U.S. also opposed an increase in the gold price because it would specifically benefit South Africa and the Soviet Union, the two major gold producers (Task Force Paper \#3, 1990, p. 10). For these reasons, the Kennedy administration went to considerable lengths to convince markets of its commitment to the official gold price.

Similarly, administration and Federal Reserve policy makers were unwilling to dampen aggregate demand for balance-of-payments purposes. The President of the Federal Reserve Bank of Atlanta, Malcolm Bryan, seems to have typified the view, at least as it prevailed among many Federal Reserve policy makers:

“...the last time the System reacted in its policy decisions primarily because of foreign developments was...in 1931. At that time, with unemployment constantly increasing and with every element in the domestic economy calling for ease, the System responded by tightening in order to protect the gold supply.” [FOMC Minutes, 10 January 1961, p.41]

He, like many other policy makers, feared a replay of the past. The United States had experienced back-to-back recessions from the third quarter of 1957 through the first quarter of 1958 and again from the second quarter of 1960 through the first quarter of 1961. These cost the Republicans the election in 1960. Kennedy pledged to "get the country moving again." The unemployment rate remained stubbornly high, and President Kennedy’s Council of Economic Advisors expected U.S. economic activity to remain below its potential level through 1963. Consequently, policy makers would not undertake deflationary macroeconomic programs.

While the overall thrust of macroeconomic policy was to promote the growth of aggregate demand, international considerations did exert some limited influence on the contours of both fiscal and monetary policies in the early 1960s. Under the Kennedy administration, the federal budget shifted from a surplus of $\$ 0.3$ billion in 1960 to deficits of $\$ 3.4$ billion in 1961, $\$ 7.2$ billion in 1962, and $\$ 4.8$ billion in $1963 .{ }^{13}$ In 1962, the administration introduced an investment tax credit and liberalized depreciation allowances primarily to spur aggregate demand, but the administration also thought that these tax cuts could improve the country's international competitiveness.

For its part, the Federal Open Market Committee (FOMC) eased policy in 1960, initially by cutting the official discount rate, then by injecting reserves through open-market operations and allowing banks to count vault cash as reserves. Thereafter, the committee held course through 1963 - sometimes under pressure from the Kennedy administration — and then tacked slowly in the other direction through 1965 (figure 5). In 107 policy decisions between the 13 September 1960 and the 1 November 1966 FOMC meetings, the committee voted 92 times to maintain the current stance of policy. ${ }^{14}$ On 15 occasions over this period, the FOMC voted for additional restraint. Most of the decisions to tighten were undertaken for a mixture of domestic and international considerations, with the domestic situation undoubtedly holding more weight. ${ }^{15}$ 
On only four occasions - three in 1963 and one in late 1964_did the committee tighten solely for international considerations. During the early 1960s, domestic considerations usually motivated committee member dissents for a looser policy, while international consideration usually motivated committee member dissents for a tighter policy. Nevertheless, monetary policy seemed relatively accommodative until late 1964 and 1965 (see figure 6).

Short-term capital outflows did affect how the Federal Reserve conducted monetary policy in the early 1960s, even if they did not alter the overall thrust of monetary policy very much. Since April 1953, except for brief periods of extreme market disorder, as in 1955 and 1958, the Federal Reserve had operated under a "bills only" doctrine; that is, the Federal Reserve confined open-market operations to the very short end of the market for U.S. Treasury securities. Faced with a potential conflict between domestic and balance-of-payments objectives, the Federal Reserve and, later, the Kennedy administration undertook a program intended to promote domestic investment and economic growth through lower long-term interest rates and to discourage short-term financial outflows through higher short-term interest rates (Martin, 1961). ${ }^{16}$ After October 1960, the System began to purchase longer-term securities, while sometimes selling Treasury bills. In addition, the Treasury began issuing more short-term securities, and government trust funds increased the portion of long-term securities in their portfolios (Yeager, 1966, p. 448). In this way, policy makers hoped to twist the yield curve for balance-of-payments purposes while maintaining an overall accommodative policy stance.

Although U.S. policy makers were unwilling to devalue the dollar or reduce U.S. aggregate demand for balance-of-payments purposes, they instituted a number of ad hoc policies designed to improve the country's competitive position and, thereby, improve the U. S. balance of payments. Both the Eisenhower and Kennedy administrations, for example, attributed postwar balance-of-payments deficits primarily to the United States' unusual military-assistance and economic-development programs. These programs sought to achieve important foreignpolicy objectives, and cutting them could have had severe political and military consequences in the antagonistic Cold War environment (Gavin, 2004). To mitigate their effects on the U.S. balance of payments, the Kennedy administration, often using the threat of troop redeployment, extended the requirements - initially developed under the Eisenhower administration — that tied military and development assistance to purchases of U.S. goods and services (Gavin, 2004). The United States also encouraged countries to hasten the repayment of their war debts and to contribute aid to developing nations.

After European currencies became convertible in 1958, U.S. traded goods came under more intense competitive pressures. In response, the Eisenhower and Kennedy administrations lobbied for the removal of discriminatory trade practices, which foreign countries leveled primarily against the United States. The United States had long tolerated these restraints as means of promoting European and Japanese development and of conserving international reserves. The Kennedy administration also undertook various efforts to promote exports through U.S. embassies and the Export-Import Bank and to reduce the duty-free allowance for U.S. tourists. In 1961, the Kennedy administration also revised the depreciation schedule, hoping to raise U.S. manufacturing productivity, improve international competitiveness, and promote exports.

While undertaking policy initiatives to improve the United States' international competitive position, policy makers here and abroad attempted to shore up Bretton Woods institutions against short-term capital flight and destabilizing reserve losses and to foster closer 
cooperation among the major developed countries. A major initiative was the General Arrangements to Borrow. With short-term financial flows larger, more mobile, and increasingly driven by uncertainties about exchange rates, countries - notably the United States and the United Kingdom-might need to borrow foreign exchange reserves to quell temporary balanceof-payments problems. Under existing quota arrangements, however, the IMF might not have sufficient foreign exchange to meet the need for specific currencies. In late 1962, the major developed countries - the G10 and later Switzerland - instituted a new credit mechanism, the General Arrangements to Borrow, within the IMF. These countries collectively pledged \$6 billion (equivalent) of their currencies to meet borrowing requests through the IMF (James, 1996, pp. 161-165).

To address the strong private demand for gold, President Eisenhower issued an order in January 1961 forbidding U.S. residents from holding gold abroad and directing any citizen holding gold to sell it by July. More importantly, in 1961, the United States, the United Kingdom, and six continental European countries formed the Gold Pool to keep the London price of gold in line with the official price. (We discuss the Gold Pool in more detail below.)

In 1963, the United States also attempted to trim long-term financial outflows through an Interest Equalization Tax. Initially, the administration levied one percent tax on interest earnings from foreign bonds sold in the United States. In 1965, the tax was broadened to include U.S. bank loans to foreigners with a maturity of more than one year. The tax exempted Canada and developing countries. By 1967, the administration raised Interest Equalization Tax to two percent (see Meltzer 1991, p. 52).

All of these initiatives attempted to address important aspects of the U.S. balance-ofpayments problem. None, however, was capable of immediately offsetting speculative financial flows, which could create contagion problems and increase dollar balances in central banks already holding excess dollars. To address these short-term speculative financial flows and to protect the U.S. gold stock, the Treasury began intervening in 1961.

\section{The U.S. Treasury's Decision to Intervene ${ }^{17}$}

In March 1961, the Exchange Stabilization Fund (ESF), with the Federal Reserve Bank of New York acting as its agent, began to intervene in the foreign exchange market for the first time since World War II. ${ }^{18}$ Increased speculative flows prompted the actions. The Treasury's operations consisted primarily of forward sales of continental currencies, which were designed to reduce forward premia on these currencies. Forward premia served as barometers of market confidence in the dollar, and when a forward premium exceeded the level consistent with existing interest-rate differential, it provided a strong incentive for financial flows.

Forward transactions offered the Treasury a number of advantages over spot trades. For one thing, the Treasury, which had only \$336 million in assets available for intervention in mid1961, did not need to commit scarce foreign-currency reserves to a transaction until the contract's maturity date and then only if the position incurred a loss. ${ }^{19}$ That, however, was unlikely. Since the ESF sold foreign currencies forward at known premia over official spot rates, the United States could only incur a substantial loss if the foreign currencies were revalued. ${ }^{20}$ The ESF typically covered its forward sales against that contingency.

The Treasury also undertook some limited spot transactions. These were largely experimental, designed to learn how the market operated and to gauge the impact of such 
operations on speculative activity. The Treasury also undertook some unusual gold swaps, which temporarily improved the mix of reserve assets on foreign balance sheets.

\section{German Mark Interventions}

On 6 and 7 March 1961, Germany and the Netherlands, respectively, revalued their currencies by approximately 5 percent, a smaller amount than market participants anticipated. Within days, funds flowed out of British sterling and, to a lesser extent, out of dollars, and into continental currencies, especially German marks and Swiss francs. In response, British authorities sold dollars to defend the pound. The speculative attack and Britain's defensive dollar sales inflated dollar holdings at continental central banks and threatened to push their dollar-to-gold reserve ratios above acceptable levels. In addition to adding to the potential demand for U.S. gold reserves, the heavy speculative flows pushed the dollar to a substantial forward discount against many of the European currencies, which tended only to reinforce expectations of further revaluations. Moreover, the limited availability of forward cover induced many market participants with dollar receivables to borrow dollars in New York or in the Eurodollar market and use these funds to buy marks in the spot market (Bulletin, September 1962, p. 1141). This hedging strategy added further to foreign central banks' dollar reserves.

On Monday, 13 March 1961, after consultations with Bundesbank and Federal Reserve officials, the ESF began selling German marks forward in an attempt to reduce the forward premium on marks, which had reached a peak of 4 percent, and, hopefully, to stabilize exchangerate fluctuations in both the spot and forward markets. A so-called "parallel" agreement covered the Treasury's risk exposure. Accordingly, the Bundesbank would supply the U.S. Treasury with any marks that it might need to fulfill the forward contracts, and the U.S. Treasury and the Bundesbank would split any profits. The forward sales reached $\$ 63$ million per week by the second week of the operations and continued at a rate of \$30 million to \$40 million per week for several weeks thereafter. The operations topped $\$ 320$ million in mid-June, but then fell off quickly (U.S. Treasury, Experience, 1962, p. 4).

The Treasury also concluded an arrangement with the German government whereby Germany would immediately prepay \$100 million of a \$587 million debt that was due to the United States in April 1961. ${ }^{21}$ Germany paid in marks. Of this amount, the ESF received \$50 million equivalent German marks. The ESF used most of it as cover for forward transactions but made small intervention sales of German marks in the New York market during June and July to lift the dollar off of its floor vis-à-vis the mark. The Treasury coordinated these operations with Bundesbank interventions. In addition, the Treasury sold the remaining \$50 million worth of German marks from the debt prepayment directly to the Bundesbank for dollars on September 1, 1962, thereby reducing the potential claim on U.S. gold reserves (U.S. Treasury, Experience, 1962, p. 5).

When the Soviets built the Berlin wall in August 1961, a substantial amount of funds quickly moved out of Germany. This reversal of financial flows provided a source for funding the U.S. Treasury's forward commitments, which, unlike the "parallel agreement," would not cause the Bundesbank to again acquire additional dollar reserves. By mid-December 1961, the Treasury liquidated all of the forward mark commitments, and although the ESF incurred small losses on its spot transactions, the overall operation accrued a \$750 thousand profit (U.S. Treasury, Experience, 1962, p. 5). 
The German mark operations convinced U.S. Treasury officials that such cooperative arrangements could provide a "first line of defense" for the dollar. With the U.S. balance-ofpayments deficit continuing, further speculative attacks seemed certain. Consequently, the ESF acquired additional German marks from the market when the Berlin crisis temporarily weakened that currency. The ESF made further forward mark sales in late December 1961 when that currency's forward premium again rose above 1 percent against the dollar. By the end of January 1962, the ESF held \$55 million worth of German marks, of which \$50 million (equivalent) were invested in German Treasury bills. Forward commitments amounted to \$10 million worth of marks. Of these, "parallel” agreements with the Bundesbank covered \$5.6 million equivalent, and ESF mark holdings covered the remainder (U.S. Treasury, Experience, 1962, pp. 6-7). The U.S. Treasury liquidated its forward commitments in German marks by the end of March 1962.

\section{Swiss Franc Interventions}

In early 1961, dollar inflows increased liquidity in the Swiss banking system and raised the dollar-to-gold ratio at the Swiss National Bank (SNB) above its legal limit. Instead of converting the excess dollar reserves immediately into gold with the U.S. Treasury, the SNB lent dollars to the Bank of England to finance Britain's pound-stabilization program. The Bank of England, however, was arranging financing through the IMF and intended to liquidate its dollar credit with the SNB (Bulletin, September 1962 p. 1143). The Swiss sought a mechanism to reduce the excess liquidity in Switzerland stemming from these dollar inflows.

The SNB believed that the inflows of fund were temporary and that forward sales of Swiss francs could stem or possibly reverse them by reducing the forward premium on francs. Swiss law, however, prohibited the SNB from operating in the forward market. Instead, on 12 July 1961, the ESF began forward sales of Swiss francs in the market through the SNB. The ESF intended to use \$15 million worth of Swiss francs, which it had acquired earlier from the SNB, as cover for the operation, but the SNB also agreed to provide additional Swiss franc cover against Treasury gold sales at a fixed price based on the existing franc-dollar exchange rate.

These initial foreign-exchange operations were small and mainly experimental, but after the Berlin crisis in August 1961 sharply increased dollar flows into Switzerland, the ESF's forward Swiss franc sales increased substantially to a peak of \$152.5 million equivalent Swiss francs by the end of November. In September, the SNB had provided the U.S. Treasury with a SF430 million (\$100 million) credit line to cover the ESF's forward commitments. To draw on this line, the U.S. Treasury issued $\$ 46$ million (equivalent) of certificates of indebtedness denominated in Swiss francs in October 1961 - the first time that it had issued foreign-currencydenominated debt since World War I. The Treasury issued the certificates in two lots, at a rate of $1.25 \%$ with a three-month maturity. The ESF received $\$ 15$ million worth of Swiss francs from the proceeds to meet Swiss franc forward commitments, and the Treasury's General Fund kept the remaining \$31 million worth of francs with the SNB. The Treasury rolled over one lot of certificates and repaid the other, as pressure on the Swiss franc subsided. In addition to these Treasury activities, the SNB doubled its dollar working balances to \$200 million and, thereby, reduced the potential gold drain that the U.S. Treasury faced (U.S. Treasury, Experience, 1962, pp. 7-8).

The Treasury viewed the Swiss franc operation, as it did the German mark interventions, as highly successful, contending that without it, the United States would have lost somewhere 
between $\$ 250$ million and \$400 million in gold reserves (U.S. Treasury, Experience, 1962, p. 8). At the end of January 1962, the Treasury had \$146.5 million worth of outstanding Swiss franc forward contracts. Profits on the operation amounted to $\$ 450$ thousand.

In February 1962, the Swiss franc began to weaken, requiring the SNB to support it with dollar sales. To acquire the necessary dollar balances, the SNB sold the Treasury $\$ 73.5$ million in gold and \$93.2 million in Swiss francs through May 1962. ${ }^{22}$ Part of the Swiss franc purchases (\$28.1 million equivalent) were on a swap basis. ${ }^{23}$ The Treasury used Swiss franc balances to liquidate forward commitments and the certificates of indebtedness as they matured (Bulletin, September 1962, p. 1145).

\section{Netherlands guilder Intervention}

In September 1961, the U.S. Treasury purchased \$15 million worth of Netherlands guilder, most of which it invested in guilder securities. With these funds providing cover, the Treasury undertook \$4.9 million (equivalent) in forward sales of guilder through the Netherlands Bank in the Dutch market beginning in January 1962. In February, the Treasury acquired an additional \$15 million worth of guilder, raising its total to \$30 million, and expanded its forward operations (U.S. Treasury, Experience, 1962, p. 10). Treasury forward guilder sales in January and February 1962 reached \$20.8 million (equivalent) (Desk Report, 1963 p. B-22). In July 1962, Britain made a large drawing of guilder from the IMF, which it used to buy dollars from the Netherlands Bank. To replenish its dollar reserves, the Netherlands Bank sold \$20 million guilder (equivalent) to the Treasury under a temporary swap agreement (Bulletin, September 1962, p. 1145). Hence, the Treasury's operations were more than covered and any excessive inflow of dollars had ended.

\section{Italian Lira Interventions}

In 1961, strong dollar inflows pushed the Italian lira to its upper parity limit and kindled rumors of a revaluation. As Italy's dollar-to-gold reserve ratio rose, Italian authorities undertook dollar swaps with domestic commercial banks that covered the latter's dollar exposure. (We discuss the mechanics of these market swaps below.) The temporary cover that these swaps provided to the Italian commercial banks encouraged them to hold dollar balances instead of converting them to lira at the Bank of Italy. The transactions could be renewed.

In January 1962, the U.S. Treasury took over \$200 million of these swaps, obligating it to deliver lira forward. The Treasury obtained some cover for its commitments through a $\$ 150$ million (equivalent) credit line with Italian authorities. The Treasury acquired an additional $\$ 100$ million of these swap obligations in March. In early 1962, the Treasury also undertook some experimental spot lira transactions (U.S. Treasury, Experience, 1962, pp. 10-11).

\section{Gold Swaps}

In addition to these foreign-currency transactions, the U.S. Treasury undertook a series of three-month gold swaps with the Swiss National Bank and with the Bank of England in 1961. In March, the Treasury sold gold to the SNB for \$25 million worth of Swiss francs under an agreement to reverse the transaction on June 30. At maturity, the Treasury rolled the swap over until 29 July 1961, and also undertook a second \$25 million gold swap, which it reversed on 13 July 1961. The Treasury undertook a \$50 million (equivalent) gold swap with the Bank of England in April 1961, which matured in equal parts in May and July of that year. 
The purpose of these gold swaps is not entirely clear. The Treasury reports that: "These gold transactions were undertaken at U.S. initiative and were designed to smooth out random short-run fluctuations in the Treasury's gold stock.” (U.S. Treasury, Experience, 1962, pp. 1112). That may be, but another objective-particularly in the Swiss case-may have been to keep the ratio of dollar reserves to gold below levels that may have required these countries to exchange dollars for U.S. gold.

\section{The Federal Reserve's Decision to Intervene ${ }^{24}$}

Both the Treasury and the Federal Reserve System viewed the Treasury's exchangemarket interventions in 1961 and early 1962 as unmitigated successes (FOMC Minutes, September 9, 1961, p. 44). The Treasury had acted against short-term speculative movements of funds and easily_and profitably — unwound its positions when those speculative pressures reversed.

The ability of the U.S. Treasury to mount another broader dollar defense, however, was severely limited. By late 1962, the ESF had assets equal to approximately \$340 million, but a large portion of this was committed to stabilization agreements with Latin American countries. This left the ESF with a paltry $\$ 100$ million equivalent in European currencies and only about \$20 million to \$25 million available for acquiring additional foreign exchange. ${ }^{25}$

The Treasury welcomed and encouraged the Federal Reserve's participation in foreignexchange-market interventions primarily because it would increase the amount of funds available for such operations. ${ }^{26}$ Since March 1961, the Federal Reserve had sharpened its expertise in the area as the agent for the U.S. Treasury and foreign central banks, but the Treasury already had access to the Desk's expertise. What the Treasury needed was the Federal Reserve's seemingly boundless capacity to create reserves and to acquire additional foreign exchange.

On 13 February 1962, the FOMC authorized intervention in the foreign-exchange market for the System's own account. By participating with the Treasury, the Fed hoped to reassert, and possibly extend, its dormant influence in this area. In fact, Chairman Martin may have wanted to bring the entire foreign-exchange operation into the Federal Reserve's domain (FOMC, Minutes, March 6, 1962, p. 72). Foreign-exchange transactions closely paralleled and often interacted with domestic monetary-policy operations, so much so that many countries viewed intervention as solely a central-bank function. The Federal Reserve Act did not explicitly preclude such activities, and indeed the System had undertaken foreign-exchange operations in the past. One way or another, U.S. foreign-exchange operations were going forward, and the System wanted to shape their development.

To be sure, support for intervention within the System at the time was not unanimous. The debates at the FOMC meetings in late 1961 and early 1962 raised issues that would resurface periodically over the next 35 years, with the exception that as time went on, dissenters became more concerned about the adverse interactions between intervention and monetary policy and less concerned about its legality than they were in the early 1960s. Nevertheless, a clear majority of FOMC members have always favored System foreign-exchange operations, provided that they did not make the Fed in any way subservient to the Treasury, that they did not raise the ire of Congress, and - eventually - that they did not interfere with the domestic objectives of monetary policy. 


\section{Legal Authority for System Interventions}

At their 12 September 1961 meeting, FOMC participants first formally discussed System participation in foreign-exchange operations. Chairman William McChesney Martin, with strong support from the New York Federal Reserve Bank, advocated the System's participation. To his mind, there was "no question but that this country was going to be in the business of foreignexchange operations," and he wanted the Federal Reserve involved either alone, or in conjunction with the U.S. Treasury (FOMC, Minutes, 12 September 1961, p. 44).

Martin contended that the public did not distinguish between the Federal Reserve and the U.S. Treasury in foreign-exchange operations. Moreover, congressmen had already asked him informally if the Fed approved of the Treasury's actions, which he interpreted as indicating that the Fed's opinion was important in these matters. To Martin, participating was imperative, even if the Fed's role was very limited. He realized, however, "that the primary direction must come from the Treasury and that everything done by the Federal Reserve must be coordinated with the Treasury.” (FOMC, Minutes, September 12, 1961, p. 49) Martin did not think this threatened the System's independence. He always contended that the Federal Reserve was independent within the government and was not independent of the government. His distinction implied that the System must coordinate and cooperate with the Treasury as far as possible and particularly in government actions that did not directly interfere with monetary-policy decisions (see Bremner, 2004, and Meltzer, 2005). Intervention, he believed, was just such an action.

The FOMC’s primary concern was Congress, whose opinion about Federal Reserve intervention in the foreign-exchange market had never been unequivocal and firm. In the current climate, if all went smoothly, Congress probably would acquiesce. Congress was aware of the balance-of-payments problem and sympathetic to the policy dilemma that it posed. If the Fed's operations incurred a substantial loss or appeared to interfere with foreign policy, however, the System's relations with Congress could deteriorate. Legislative support for the operations, which Congress never explicitly offered, would have eased the FOMC's concerns. At a minimum, however, the FOMC wanted to be sure that its actions were legal.

The Federal Reserve Act did refer to specific types of foreign-exchange transactions, and at least seven times between 1924 and 1929 the Federal Reserve Bank of New York extended credits to foreign central banks to shore up their reserves in defense of their currencies (Task Force Paper \#1, 1990, pp. 4-5). In 1925, for example, the Federal Reserve Bank of New York made \$200 million worth of gold available to the Bank of England with the understanding that the Bank of England would place proceeds from any gold sales in a sterling investment account for the Federal Reserve Bank of New York (see chapter 2). In 1933, however, Senator Carter Glass, whom many regarded as the father of the Federal Reserve Act, criticized these transactions, indicating that such "stabilization operations" were inconsistent with the original act. At that time, as discussed below, the Board of Governors took a position that was not inconsistent with Senator Glass’s view. In 1934, Congress passed the Gold Reserve Act, establishing the ESF specifically for the purpose of intervening (see chapter 3). But, in passing the Gold Reserve Act, did Congress mean to preclude the Federal Reserve from this arena?

In 1961, Howard Hackley, the Board of Governors' general counsel, provided a legal interpretation of the Federal Reserve Act that the FOMC would now adopt (see Hackley 1961, Todd 1992). ${ }^{27}$ The often-cited "Hackley Memo" argued that various sections of the Act-when considered together — authorized the Federal Reserve System to hold foreign exchange, to 
intervene in both the spot and forward markets, and to engage in swap transactions with foreign central banks and with the U.S. Treasury.

Section 14 of the Act seemed the key. It allowed the System to purchase and sell both spot and forward "cable transfers" in both domestic and foreign markets. Since cable transfers were the standard means of acquiring foreign exchange in the early part of the century, section 14 seemed to sanction-according to Hackley's interpretation-both types of foreign-exchange intervention. More generally, however, section 12A(c) instructed the Federal Reserve System to undertake open-market operations - including transactions in foreign exchange - that accommodate commerce and business by promoting sound credit conditions in the United States. Defending the dollar, cooperating with foreign central banks and the IMF, and promoting trade certainly seemed consistent with this general objective. Section 12A(b) of the Act also specifically required the FOMC’s authorization for all such open-market operations.

In addition, section 14(e) allowed the Federal Reserve to hold foreign exchange in the form of open accounts in foreign countries, to appoint correspondents, and to establish agencies. $^{28}$ These are necessary aspects of an intervention operation, particularly if the Federal Reserve hoped to operate through a foreign commercial bank or a central bank in a foreign market. In the 1930s, however, the Board of Governors interpreted this clause narrowly, arguing that the Act allowed the System to open accounts only to facilitate direct intervention transactions, but that it did not allow the System to hold foreign currency beyond what was immediately necessary for intervention. This interpretation seemed to preclude holding foreigncurrency positions acquired outright or through swaps. In 1961, Hackley broadened the interpretation, arguing that the FOMC instead could construe the Act as allowing the System to maintain such accounts provided that it had a reasonable expectation of using them to finance intervention (Hackley, 1961, p. 13). Accordingly, the System now regarded section 14(e) as authorizing it to undertake swaps with other central banks and eventually to amass a huge portfolio of foreign exchange. Hackley's interpretation was a clear change in the Board's attitude and was in agreement with the Federal Reserve Bank of New York's original actions in the 1930 s. $^{29}$

More problematic for the System, however, was finding legal authority for purchasing foreign exchange from the ESF on either a permanent or temporary (warehousing) basis. ${ }^{30}$ The Banking Act of 1935 prohibited the Federal Reserve from purchasing government obligations except in the open market. Although Congress had permitted some direct purchases of government securities during World War II, and although the Fed retained some very limited authority to do so after the war, Congress clearly did not want the System lending resources to the Treasury "in a manner that might be inconsistent with the System's monetary and credit responsibilities” (Hackley, 1961, p. 18). Hackley argued that swap agreements with the Treasury did not violate the open-market provisions of the Banking Act of 1935. In contrast to government securities, foreign currency was not a liability on the U.S Treasury's balance sheet; therefore, that agency was part of the open market for foreign exchange. Moreover, Hackly asserted, the United States was a "domestic corporation." This was a necessary criterion because the Federal Reserve Act also limited open-market operations to domestic corporations. In Hackley's opinion, the System could lawfully buy and sell foreign exchange from the ESF or the Treasury. ${ }^{31}$ Unlike most of the legal controversies associated with Federal Reserve intervention, the debate about the appropriateness of warehousing would never quite disappear (see Broaddus and Goodfriend, 1996, and Hetzel, 1996). Opponents would consistently argue that warehousing 
constituted a System loan to the ESF using foreign exchange as collateral and was, therefore, inappropriate. It contravened principles of central-bank independence and thereby impinged on the credibility of monetary policy. Proponents would eventually argue that warehousing did not constitute a loan, but instead was a straightforward and permissible asset swap between the two agencies.

\section{Other FOMC Objections}

Aside from the question of the Federal Reserve's legal authority for intervention, four other key issues arose during the FOMC's discussions in late 1961 and early 1962. One was political: Some members of the FOMC feared that even if the Federal Reserve Act did provide legal authority for intervention, Congress might interpret the Federal Reserve's involvement as a budgetary bailout for the Treasury. Congress established the ESF specifically for the purpose of intervening in the foreign-exchange market, and capitalized the fund with an appropriation of $\$ 2.0$ billion. In 1945, Congress used \$1.8 billion of ESF funds to pay the U.S. contribution to the IMF. Karl Bopp, the president of the Federal Reserve Bank of Philadelphia, argued that these events suggested that Congress intended to limit the amount of funds that the ESF could devote to foreign-exchange operations (FOMC, Minutes, 12 September 1961, pp. 49-50). If so, then the System's unlimited participation with the ESF might appear as a method of circumventing Congress's budgetary authority. If the ESF wanted more funds for intervention, it should seek a larger Congressional appropriation. ${ }^{32}$ Moreover, the ESF made loans to developing countries and currently had a substantial amount committed to Latin America. These were essentially foreign-policy actions related to State Department functions. Might Congress view the Federal Reserve's foreign-exchange operations as a back-door means of financing these foreign-policy operations? Could the Federal Reserve become embroiled in a dispute among Congress, the Treasury, and the State Department about foreign policy?

A second FOMC concern focused on the bureaucratic authority for intervention and its implication for Federal Reserve independence. Congress created the ESF and vested the Treasury with primary responsibility for intervention in part because of its dissatisfaction with Fed interventions during the 1920s and 1930s. If the Treasury had primary responsibility for intervention, as Chairman Martin acknowledged, could it direct how the Federal Reserve operated for the System account? The U.S. Secretary of the Treasury, the nation's primary financial officer, is responsible to both the president and the Congress of the United States for formulating and implementing all U.S. financial policies, and the Gold Reserve Act of 1934 gave the Treasury primary responsibility for intervention. If, as the FOMC now claimed, the Federal Reserve Act authorized the System to conduct foreign-exchange operations independently, the potential for conflict with the Treasury existed. At a minimum, the System's foreign-exchange operations cannot act in a way contrary to U.S. international financial policies (Task Force Paper \#6, 1990). In subsequent testimony before the House Committee on Banking and Currency, Chairman Martin pledged to avoid conflicts with the Treasury in conducting the System's intervention operations, saying "the System will, of course, coordinate its foreign-exchange operations with those of the Treasury Stabilization Fund” (quoted in: Task Force Paper \#6, 1990, p. 1). Coordination would be on a day-to-day basis.

In addition, the Board staff assumed that the Treasury could not direct the Federal Reserve in operations for the System's account (FOMC, Minutes, 12 September 1961, p. 51). Coombs (1976, p. 72) claims that by agreement the Treasury could veto System intervention operation with which it did not agree, and the System could refuse to undertake any operations 
for its own account with which it did not agree. In an 18 December 1961, letter to Chairman Martin, Treasury Secretary Dillion pledged, "the Treasury on its part would naturally want to avoid impinging on the independence of the Federal Reserve System within the Government." 33 The lines of authority were not clearly defined in the early 1960s, and experience would show that the Treasury's preeminence in the area would indeed create difficulties for the Federal Reserve System, as when the System attempted to stop intervening in the 1990s.

On the surface, the third concern focused on the ability of the Federal Reserve to respond quickly to speculative attacks against the dollar, but underlying this may have been a deeper concern about who would actually run the show within the Fed and how it would affect the relative authority of the FOMC, the Board of Governors, and the Federal Reserve Bank of New York. Many within the Federal Reserve System thought that a special subcommittee of the FOMC was necessary to directly oversee foreign-exchange intervention because an emergency situation could quickly arise when the full committee was unavailable for consultation and immediate decisions. Making a quick response time all the more crucial, the Fed needed to coordinate most operations with foreign central banks, which might be five or even twelve hours ahead. In a memorandum dated 8 February 1962, the Board’s General Counsel, Howard Hackley, recommended that foreign-exchange operations be put under the supervision of the Board of Governors instead of the FOMC. The Board meets almost daily and has foreignexchange experts on staff. Moreover, while Hackley contended that the law allowing the Federal Reserve to engage in foreign-exchange operations was clear, he also argued that giving control to the Board of Governors instead of the FOMC was "...more defensible from a legal standpoint." (FOMC, Minutes, 13 February 1962, p. 64). Others, including Governor Robertson, who opposed Hackley's interpretation of the Federal Reserve's authority for intervention, and the president of the Federal Reserve Bank of Cleveland, W. D. Fulton, supported Hackley by arguing that the Board was more of a "public body" than the FOMC. Apparently, because elected officials appointed governors, but not Federal Reserve Bank presidents, the former had more authority to deal with issues that touched the fringe of foreign policy than the latter. The president of the San Francisco Federal Reserve Bank, Eliot Swan, however, articulated the underlying concern with Hackley's recommendation: “To shift from the Committee to the Board might give support to those who would like to change rather basically the fundamental structure of the System.” (FOMC Minutes, 13 February 1962, p. 68)

While most participants favored maintaining FOMC authority, many thought that a smaller management group was necessary to deal with emergency situations. At issue was the extent of a subcommittee's authority. A subcommittee with broad authority might not confine its activities to administration, but would instead actually make policy (FOMC Minutes, 5 December 1961, p. 71). Ultimately, the FOMC decided to authorize a committee consisting of the Chairman and the Vice Chairman of the FOMC and the Vice Chairman of the Board to conduct operations when the full committee was unavailable. The subcommittee, however, was to act within FOMC guidelines, which we discuss below. This subcommittee could, however, set maximum amounts of individual currency holdings, establish exchange-rate limits, review and approve any agreements between the Federal Reserve Bank of New York and foreign central banks, and take emergency actions when the full FOMC was unavailable.

Chairman Martin also wanted the Special Manager, who actually undertook intervention operations through the Foreign Exchange Desk at the Federal Reserve Bank of New York, to be an employee of the FOMC and not, as currently was the case, an employee of the Federal 
Reserve Bank of New York. Not surprisingly, the president of the Federal Reserve Bank of New York objected that this move would reduce the bank's authority-specifically the authority of its directors - and wanted to maintain the current set-up. The FOMC, however, accepted the Chairman's recommendation and the Special Manager became an employee of the FOMC (FOMC, Minutes, 17 April, 1962 pp. 2-3).

A final issue focused on the exact role of intervention. Policy makers at the Federal Reserve all seemed to agree that the broad objective of intervention was to defend the dollar, thereby reducing gold outflows and bolstering confidence in the dollar's parity. But how extensive should these operations be? At one point, the Federal Reserve Bank of New York suggested undertaking seasonal and cyclical interventions to smooth out anticipated balance-ofpayments flows (FOMC, Minutes, 5 December 1961, p. 49). Some FOMC members, however, were concerned that prolonged intervention might actually interfere with balance-of-payments adjustment and actually prolong disequilibrium. Governor Mitchell argued that if a foreign country had a balance-of-payments surplus and wanted to acquire gold, the United States should accommodate that country. The United States, therefore, needed a policy to facilitate an orderly loss of gold. Intervention might prevent a sudden loss of gold, but the danger was that absent a fundamental policy change, the demand for gold would grow and eventually worsen confidence in the official gold price. Similarly, Governor King feared that "people would be likely to put too much reliance on these operations to guard the dollar..." (FOMC, Minutes, 13 September 1961, p. 55). Governor Roberts also feared that if the Fed repeatedly disrupted the private market's pricing process, the willingness of private market participants to make a market in foreign exchange might deteriorate (FOMC, Minutes, 5 December 1961, p. 60). For these reasons, the FOMC favored only temporary interventions that would offset transitional, disequilibrating disruptions in the foreign-exchange market and that would not attempt to avoid fundamental market adjustments. As time would tell, however, distinguishing between temporary, disequilibrating developments and those of a more fundamental nature was extremely difficult.

\section{A Cautious Approach}

Most FOMC members favored intervention and were sympathetic to Hackley's interpretation of the Federal Reserve Act. Nevertheless, they wanted to proceed cautiously and to first seek, with the cooperation of the Treasury, legislative clarification from Congress (FOMC, Minutes, 5 December 1961, pp. 78-79). In the face of this hesitancy, Chairman Martin, Federal Reserve Bank of New York President Alfred Hayes, and First Vice President of the Federal Reserve Bank of New York Charles Coombs stressed that foreign-exchange markets were currently very sensitive to speculative pressures. They argued for going forward on an emergency basis and seeking Congressional approval afterwards. (The Treasury made a similar appeal.) The sense of urgency swayed the FOMC. While urgency was the Chairman's stated motivation, he also may have hoped to avoid a full-fledged Congressional review of the System's role in intervention, especially one that might provide an opportunity for other changes in the Federal Reserve Act. ${ }^{34}$

On 23 January 1962, with two members dissenting, the FOMC approved foreignexchange operations for the System's account on an experimental basis (FOMC Minutes, 23 January 23, 1962, p. 41). Governor Mitchell objected, contending that the System first needed Congress's explicit approval. Similarly, Governor Roberts dissented, arguing that the Federal Reserve Act did not clearly authorize these types of stabilization actions; that the FOMC was 
basing its decision on incidental authority in the Act, and that Congress intended to confer only limited authority for such actions to the Treasury's ESF. ${ }^{35}$

In late February 1962, Chairman Martin reported to the House Committee on Banking and Exchange that the Federal Reserve "had recently decided to reenter the field of foreignexchange transactions.” He reported that the General Counsel for the U. S. Treasury and the Attorney General of the United States concurred with Hackley's interpretation of the legal basis for the FOMC's decision. In general, the U.S. Congress accepted the Federal Reserve's interpretation of its authority. Representatives Henry Reuss and Wright Patman, however, did not agree. Representative Reuss contended:

Much of the operation that you are doing...seems to me to duplicate the foreign exchange stabilization operation that the Secretary of the Treasury has very properly undertaken pursuant to the Gold Reserve Act of 1934. To me this is a tremendous power you have taken upon yourself, and I must serve notice on you right now that I consider this an usurpation of the powers of Congress... You come in here and tell us that you propose to go off on, if I may say so, a frolic of your own, involving unspecified sums without the slightest statutory guidance.” (quoted in Hetzel, 1996)

The System has since reported on its foreign-exchange operations, and Congress has been aware of its activities. In the 1980s, under the Monetary Control Act, Congress amended section 14(B)(1) of the Federal Reserve Act to allow the System to invest foreign currencies acquired through its foreign-exchange operations in short-term foreign government securities. ${ }^{36}$ The FOMC has interpreted this as tacit Congressional approval of the Federal Reserve's foreignexchange operations. Serious concern about the legal authority of the Federal Reserve's intervention activities never again arose within the FOMC. The System continued to worry that Congress might view intervention and related activities as interfering with its appropriations power, and remained concerned about how intervention conducted in conjunction with the Treasury might interfere with its ability to conduct such operations independently. Eventually, as we detail in chapter 6, FOMC participants worried that intervention and, especially warehousing, interfered with Federal Reserve independence and the credibility of monetary policy (see Broaddus and Goodfriend, 1996, and Hetzel, 1996).

Rules of Engagement ${ }^{37}$

On 13 February 1962, the FOMC approved the Authorization Regarding Open Market Transactions in Foreign Currencies, the Guidelines for System Foreign Currency Operations, and the Continuing Authority Directive on System Foreign Currency Operations. These documents provided the FOMC's instructions to the Subcommittee of Foreign Exchange, the Special Manager, and the Foreign Exchange Desk of the Federal Reserve Bank of New York for undertaking foreign-exchange operations for the System's account.

The Authorization listed the goals of the operations and sanctioned specific types of transactions. As stated in this document, the basic purposes of the operations were: (1) to safeguard the value of the dollar, (2) to improve the efficiency of payments by avoiding disorderly conditions, (3) to promote monetary cooperation among central banks and international organizations, (4) to moderate temporary international payments imbalances that 
might adversely affect reserves, and (5) to foster growth in international liquidity compatible with the needs of an expanding world economy. In addition to these basic purposes, the document also listed more specific aims for the Federal Reserve's transactions. These were: (1) to protect the U.S. gold reserve from international payments flows stemming from temporary disequilibrating forces or transitional market disturbances, (2) to temper abrupt changes in spot rates and moderate forward premia and discounts judged to be disequilibrating, (3) to supplement exchange arrangements such as those made through the IMF, and (4) to provide a means whereby reciprocal holdings of foreign currencies might contribute to international liquidity needs. The Authorization allowed spot and forward transactions at prevailing rates in both U.S. and foreign markets and allowed transactions with the ESF.

The Authorization also provides guidance with respect to communications. Besides keeping the FOMC informed of the operations, the Authorization required close consultation with foreign central banks, and also instructed the chairman to keep the Secretary of the Treasury fully advised about System foreign-currency operations. The chairman was to consult with the secretary on all matters that related to Treasury responsibilities, and the Federal Reserve staff was to transmit all pertinent information about System foreign-currency operations to the U.S. Treasury. A daily conference call would take place among representatives of the Federal Reserve Board, the Treasury, and the Federal Reserve Bank of New York (see U.S. Treasury, Memorandum, 1962, pp. 5-6). At this call, participants would discuss current market conditions and any planned operations. At the end of the day, the Federal Reserve Bank of New York would provide all principals a summary of the day's operations. The Authorization also instructed the chairman to report periodically to the National Advisory Council on International Monetary and Financial Problems. The FOMC also understood that the System and the Treasury would consult before "either entered into any agreements with foreign central banks or governments regarding possible foreign-currency operations.” (FOMC Minutes 13 February 1962, p. 93). The Authorization established the aforementioned subcommittee for foreignexchange operations to instruct the special manager when the full FOMC was unavailable.

The Guidelines are more explicit with respect to current operations. On 13 February 1962, they limited the holdings of foreign currency to an amount that would allow the ForeignExchange Desk to "exert a market influence," and to cover outstanding forward commitments. It also instructed the Federal Reserve Bank of New York on operating procedures. The Desk was to transact at prevailing exchange rates and was not to attempt to establish rates that were inconsistent with underlying market forces. Absent explicit authorization to the contrary, the Federal Reserve Bank of New York was to purchase foreign currencies at, or below their par values and was to lower the rate that it paid for any foreign currency as the amount that the Bank held approached the limits that the FOMC set. The Federal Reserve Bank of New York was to follow a similar technique for sales of foreign exchange. The document also required that operations be coordinated in the sense of not acting at cross purposes with another central bank.

The Guidelines indicated that spot intervention was appropriate "whenever exchangemarket instability threatens to produce disorderly conditions" and listed some conditions (e.g., political tensions, wide interest-rate differentials) that might signal such developments (FOMC Minutes 13 February 1962, p. 88). Forward operations were appropriate when forward premia or discounts were inconsistent with interest-rate differentials or when such forward operations "encourage[ed] the retention or accumulation of dollar holdings abroad.” (FOMC Minutes 13 February 1962, p. 89) This latter condition allowed for swap transactions. The Guidelines also 
allowed the FOMC to take over outstanding forward contracts that the ESF originated. The System also agreed to purchase foreign currencies that the Treasury acquired under existing credit arrangements with foreign central banks and governments and to do likewise-after consultation - in the future, and to buy foreign currencies that the Treasury acquired from the IMF (FOMC Minutes, 13 February 1962, p. 94). Moreover, the System agreed "to purchase currencies...from the Treasury either outright or under mutually satisfactory resale agreement [warehousing], in the event that exchange-market developments obliged the Fund to exhaust available resources.” (FOMC Minutes, 13 February 1962, p. 94).

The initial Continuing Authority sanctioned transactions in: British pounds, French francs, German marks, Italian lira, Netherlands guilders, and Swiss francs, with total holdings not to exceed $\$ 500$ million. This limitation and listing of currencieswould frequently change to accommodate broader operations.

\section{Acquiring an Initial Position}

With a balance-of-payments deficit and the dollar often trading at the lower end of parity bands, the Fed needed foreign exchange to mount a dollar defense, but any purchase of foreign exchange would supply more dollars to the market, put additional downward pressure on the dollar, and increase the potential drain of U.S. gold reserves (see U.S. Treasury, Memorandum, 1962). The Fed looked to acquire a small amount of foreign exchange from the market or from foreign central banks whenever a fortuitous opportunity presented itself, and some occasions arose in early 1962. In addition, the Treasury sold outright to the Federal Reserve System \$32 million equivalent German marks in February and March, and \$0.5 million equivalent each in Swiss francs, Netherlands guilder, and Italian lira (Desk Report 1963). The Treasury also agreed to sell to the Federal Reserve System, either outright or through repurchase agreements, currencies held by the ESF, if the ESF exhausted its available dollar funds for foreign-exchange operations. These currencies permitted the System to open accounts with the central banks of Germany, Switzerland, the Netherlands, and Italy. The System already had British sterling and French francs in accounts with the Bank of England and with the Bank of France (FOMC Scope and Character, 1962, p. 1). ${ }^{38}$ Holding large balances in a wide range of foreign currency increased the risks of a valuation loss (Coombs 1976, p. 74).

The System also established a series of reciprocal currency arrangements-the swap network-with major central banks. The swap network, which became the Federal Reserve's key mechanism for intervention, provided the System and foreign central banks an off-market means of financing interventions during the Bretton Woods era.

\section{Mechanisms of Exchange-Rate Policy}

During the Bretton Woods era, the Federal Reserve System and the U.S. Treasury intervened using various mechanisms, which we review in this section. Although the System the Treasury often worked in tandem, adopting the similar techniques at the same time, a clear division of responsibility existed between these agencies. The Federal Reserve focused on shortterm operations, typically financed through drawings on its swap lines. Ideally, the System would soon reverse these transactions, so exchange-rate exposure and exchange loss generally were not big concerns. The U.S. Treasury, as noted, often engaged in similar short-term operations, but because of its clearer authority for intervention, the Treasury also undertook operations of a longer-term nature. Most importantly, as per a 23 July 1962 understanding between Chairman Martin and Treasury Secretary Fowler, the Treasury stood ready to backstop 
System operations if market conditions prevented the Federal Reserve from reversing a swap drawing on time. To do so, the Treasury could either issue foreign-currency-denominated securities — short-term certificates of indebtedness or long-term Roosa bonds — or draw foreign exchange from the International Monetary Fund, or sell gold for foreign exchange and then sell the proceeds of these transactions to the Federal Reserve. In addition, the U.S. government sometimes cajoled foreign governments into holding larger dollar portfolios.

\section{Reciprocal Currency Agreements-Swap Lines}

From 1962 until the closing of the U.S. gold window in August 1971, the Reciprocal Currency Arrangements, or swap lines, were the Federal Reserve System's key mechanism for defending the U.S. gold stock, and they became an important means for temporarily providing dollar liquidity to foreign central banks. ${ }^{39}$ Swaps involve the simultaneous spot purchase and forward sale of one currency against another. ${ }^{40}$ The transactions provided both the System and participating foreign central banks with short-term credits for dealing with temporary and unwanted changes in official dollar reserves. Temporary - the key operative word-implied reserve changes that monetary authorities expected to quickly turn around. Countries were not to use swap drawings to avoid fundamental balance-of-payments adjustments, although distinguishing between temporary and fundamental problems proved a formidable, often impossible, task.

Ideally, "the very existence of the arrangements, even when they [were] not used, [was] thought to have a stabilizing effect.” (Holland, 1 February 1967, pp. 4-5; see also Solomon 13 August 1971) This passive influence occurred through two channels: For one thing, the swap lines signaled central-bank cooperation and, thereby, mitigated uncertainty that otherwise might foster speculative activity. In addition, the existence of the swaps raised the potential costs of speculation. Central banks often increased the swap lines during tumultuous periods, but as figure 7 shows, they never drew on the full capacity of the lines. Swaps offered a threat to speculators.

The swap mechanism functioned as follows: The Federal Reserve System would sell U.S. dollars spot to a foreign central bank for its own currency and immediately sell that foreign currency back to that same foreign central bank for delivery at a set future date (see Task Force Paper \#9, 1990). ${ }^{41}$ The repayment would terminate the swap drawing, but not the line. Central banks, in almost all cases, annually negotiated_on a bilateral basis_overall credit limits for the swap lines. Drawings initially had a term of three months, but could be renewed once if the parties agreed. (The swap line with the National Bank of Belgium had an initial six-month term.) Ideally, banks were not to seek a second renewal, and "every effort was made to prevent a facility from being in continuous use for as long as a year.” (Task Force Paper \#9, 1990, p. 3) The System's lines-unlike the Treasury’s—-were reciprocal, meaning that either party could initiate a drawing.

Because swaps provided only temporary credits under a pegged-rate system, they were unlikely to result in large losses. Quite the contrary, when all things work according to design, the central bank that drew on the swap line tended to profit from the operation, because it sold foreign exchange against its own currency when its own currency was trading below par and bought foreign exchange to repay the line when its currency had appreciated (Bodner 1970, p.1). Because swaps were relatively safe, central banks did not apply conditions, such as the adoption 
of macroeconomic policies or the application for funds from the IMF, to their use. ${ }^{42}$ This made them readily available. Only a two-day notice was necessary for a drawing.

Participants undertook the spot leg of the swap at prevailing market exchange rates. During the Bretton Woods era, the forward leg of any transaction was undertaken at the same exchange rate. Hence, the swap itself incurred no exchange-rate risk. The central bank that drew on a swap line and used the foreign exchange for intervention, however, was exposed to exchange-rate risk, since it did not know the precise price of obtaining foreign exchange to retire the swap drawing. To protect the debtor bank should the creditor bank revalue its currency during the term of a swap drawing, the lines included "revaluation clauses" allowing the borrowing central bank to obtain from the creditor central bank sufficient foreign exchange to repay its obligation at a market-based exchange rate prevailing prior to the revaluation. As we will see revaluation clauses proved problematic in the face of a dollar depreciation, and they did not apply to the adoption of a float. The System exercised a revaluation clause on once, in May 1971, against the Netherlands Bank.

In all cases, the central bank initiating the swap also paid interest on its borrowings. The creditor central bank invested the foreign currency that it acquired from the debtor central bank for the term of the swap in a time deposit or in some other interest-earning asset. (The debtor would do likewise with any unused balances.) During the Bretton Woods era, both the interest rate that the creditor country received and the interest rate that the borrower received were equal to the interest rate on three-month U.S. Treasury bills. ${ }^{43}$ If necessary, interest effectively could be paid by adjusting the spot and forward exchange rates on the swap.

In March 1962, the Federal Reserve established its first swap line with the Bank of France. $^{44}$ The System drew on this line, renewed it once, and repaid the line in August 1962. The System did not intervene with the funds so acquired; the operation was a test of the mechanisms. The French franc swap line then existed on standby status. In May 1962, the System established a second line with the Bank of England. Again, the System drew on the line to test the "telex, investment, and other technical procedures" involved with the operations (Coombs 1976, p. 79). By the end of that year, the System had established lines with eight key European central banks and the Bank of Canada that provided up to $\$ 900$ million equivalent in foreign exchange. ${ }^{45}$ The network continued to grow, and it evolved from a small, very shortterm credit facility in 1962 to a large, intermediate-term facility by the closing of the U.S. gold window on 15 August 1971 (see figure 7). By then, the swap network totaled \$11.2 billion equivalent and involved 14 central banks, having picked up the central banks of Denmark, Japan, Mexico, Norway and Sweden over the intervening years. ${ }^{46}$ In addition, the term of a typical swap drawing increased from the original 3 months to 6 months. The expansion of the swap lines was a natural consequence of both the mounting threat to the U.S. gold stock and the growing volume of international transactions, but the increasing length of swap drawings and the frequent tendency to renew them suggested that the underlying disequilibrium was of a more fundamental than temporary nature.

\section{Providing Cover}

Between 1962 and the closing of the U.S. gold window in 1971, the Federal Reserve borrowed $\$ 11.5$ billion worth of foreign exchange through its swap lines (see figure 8). Usually-but not exclusively — the System used these funds to provide foreign central banks with cover for temporary, undesirable surges in their dollar balances and, thereby, to discourage 
these central banks from quickly converting unwanted dollars into gold with the U.S. Treasury. To accomplish this, the System used the foreign exchange that it obtained in a swap drawing to acquire dollars from the same foreign central bank. This set of transactions - the swap drawing and the acquisition of dollars_-left the foreign central bank holding exactly the same amount of dollars as it did before the swap took place. The dollars that the foreign central bank now held, however, were free of foreign exchange risk since the Federal Reserve contracted to buy them back via the forward leg of the swap at a set exchange rate.

By far, the System undertook the largest cover operations with the Swiss National Bank (SNB), and these serve as an example of the pitfalls and benefits of these types of operations. Between 1962 and 1971, the System drew nearly \$4.7 billion equivalent Swiss francs from swap lines with the Swiss National Bank and the Bank for International Settlement (BIS). The System established a Swiss franc swap line with the BIS in 1962 to supplement its line with the SNB, which faced statutory limits on loans to non-Swiss banks (Task Force Paper \#9, 1990, p.11). The Swiss franc drawings amounted to over $40 \%$ of all System drawings during the Bretton Woods era.

At the time, the Swiss franc functioned as a key safe-haven currency, attracting funds that flowed out of British pounds, U.S. dollars, and other overvalued currencies. Because these flows involved dollars either directly or as a vehicle currency, they typically left the SNB holding unwanted dollar exposures. Absent a mechanism to provide cover, the SNB undoubtedly would have shed these dollars for gold.

In mid-1962, for example, persistent speculative inflows lifted the Swiss franc to the upper limits of its parity range against the dollar. Forced to intervene, the SNB acquired U.S. dollars in excess of its informal limits. Special Manager Charles Coombs feared that "Unless we can ... mop up a sizable proportion of the dollars recently taken in by the Swiss National Bank we face the prospect of very large gold losses which might easily trigger off an avalanche of demand from other quarters.” (FOMC Minutes, 10 July 1962, pp. 52-53; emphasis added). In response, the System opened the two aforementioned Swiss franc swap lines, each for $\$ 100$ million, and immediately drew $\$ 50$ million worth of Swiss francs from each line to provide cover to the SNB.

Because they matured in three months, shortly after making the drawings, the System looked for opportunities to acquire Swiss francs to repay the swaps. A window of opportunity presented itself from late summer until the Cuban missile crisis in mid-October 1962, during which time pressures on the Swiss franc subsided. The System bought Swiss francs in the market, but could not acquire enough Swiss francs to pay off all of its outstanding obligations, because, despite the relative calm, the Swiss franc often traded above its par value, and the FOMC prohibited the Desk from buying foreign exchange at exchange rates above par. ${ }^{47}$ The System's second option was to buy the necessary Swiss francs from the SNB, but with dollars still trickling into Switzerland, the SNB was reluctant to sell Swiss francs to the Desk and acquire still more dollars in the bargain. On 2 October 1962, Coombs asked the FOMC to renew for an addition three months all outstanding Swiss franc swap lines with the SNB and the BIS. This seemingly innocuous roll-over, however, pointed to the fundamental problem with the swap network. How much time was necessary to distinguish between a temporary and fundamental disequilibrium, or when should the U.S. Treasury settle in gold? 
In early 1963, a second window of opportunity opened, and the System managed to liquidate $\$ 80$ million worth of its \$105 million equivalent Swiss franc obligations, by buying Swiss francs in the market, from the U.S. Treasury, and from the SNB. The System, however, also took a new tack. On 28 May 1963, the FOMC authorized the Desk to swap \$13 million equivalent British pounds from its portfolio for Swiss francs with the BIS. Despite the limits on swap maturities and rollovers, the System did not repay this drawing until the end of 1964-well over one year. Using this, so-called, third-party swap to extinguish a bilateral swap, however, does not discharge the System's short position, but merely changes the currency composition of that position and extends the maturity of the System's liability. In addition, it reduces the liquidity of the System's overall long position in foreign exchange (see Board of Governors 21 March 1966, p. 35).

By mid 1963, rising Swiss money market rates attracted renewed dollar inflows, and following the assassination of President Kennedy in November 1963, the Swiss francs again reached the top of the parity band. The situation led to new rounds of intervention, with the System providing additional cover to the SNB. By early 1964, the System owed the SNB \$70 million worth of Swiss francs and owed the BIS \$145 million worth of Swiss francs.

Once again the Swiss franc traded above par, and the System could not acquire sufficient Swiss francs to repay its outstanding commitments. Consequently, in May 1964, the parties involved agreed on a series of measures to reduce the System's outstanding debt. The Treasury issued \$70 million worth of Swiss-franc-denominate Roosa bonds to the BIS and sold the proceeds outright to the Federal Reserve, which repaid an equivalent amount of Swiss-franc debt to the BIS. Through this transaction, the BIS substituted long-term dollar-denominated debt for short-term dollar-denominated debt on its books. In June 1964, the Bank of Italy swapped \$100 million equivalent Italian lire for Swiss francs with SNB and sold the Swiss franc thus acquired to the Federal Reserve System for dollars to bolster Italian reserves. The System retired its outstanding commitments to the SNB, but to do so, the SNB had substituted lira-denominated assets for dollar-denominated assets on its books. In late June, the System paid down its Swiss franc debt to the BIS with francs that it obtained via the U.S. Treasury from gold sales to the SNB.

In late 1964 and early 1965, funds again poured into Switzerland, and the System again drew on its Swiss franc swap lines to offer cover. This time, however, the situation quickly reversed. By spring, Swiss commercial banks began placing funds abroad, and the SNB eventually began selling dollars in support of the Swiss franc for the first time since 1962. Under these circumstances the System was able to acquire Swiss francs in the market, from the SNB, and through transactions with other central banks to cover its outstanding obligations by midyear. The System's swap line reverted to standby status although the System still had a Swiss franc obligation with the BIS stemming from a German mark cross swap. In 1966, funds again moved out of Switzerland and into the Eurodollar market, and the Swiss National Bank sold dollars to moderate the franc's decline. To replenish its dollar reserves the SNB sold Swiss francs to the Treasury and System. In addition, the SNB sold gold to the Treasury.

Operation to provide cover persisted until the closing of the gold window in August 1971. The System frequently encountered problems similar to those experienced with Swiss franc swaps and resorted to similar fixes. All in all, however, the System's swap lines often succeeded in preventing countries from converting temporary inflows of unwanted dollar reserves into Treasury gold. Between 1962 and the end of 1969, Federal Reserve swap drawings 
totaled nearly $\$ 7$ billion equivalent. ${ }^{48}$ In general, reversals in flows into foreign countries—as described in the Swiss franc example-enabled the System to repay approximately three-fourths of its swap drawings. Repayments out of gold sales amounted to only \$186 million. The issuance of U.S. Treasury bonds denominated in foreign currencies and U.S. drawings on the IMF financed the remainder. From the end of 1969 through the 12 August 1971, the System drew $\$ 4.5$ billion in foreign currencies through the swap lines. Suggestive of the deteriorating position of the dollar, the Treasury had to finance most of the repayments through the sale of reserve assets.

\section{Temporary Liquidity}

The Federal Reserve's swap lines were reciprocal, meaning that foreign central banks could initiate drawings when they need a temporary increase in their dollar liquidity. During the Bretton Woods era this became an important function of the swap lines. Between 1962 and 1971, foreign central banks initiated drawing of $\$ 15.3$ billion dollars (figures 8). The Bank of England undertook over one-half of these drawings in defense of the pound's exchange rate, as we discuss below.

Canada was the first to draw on the new swap lines for liquidity purposes. In March 1962, the Canadian dollar, which had floated since September 1950, came under strong downward pressure as monetary and fiscal policies eased and speculative pressures on the Canadian dollar intensified. ${ }^{49}$ In an effort to restore stability and confidence to the market, Canada established a par value for the dollar at US\$ 0.9250 on 2 May 1966. Intense speculative pressure followed because the market anticipated a rate closer to US\$ 0.90 and believed the new peg would not hold.

On 26 June 1962, the Federal Reserve System opened with the Bank of Canada a \$250 million swap line-five times the size of any other line then in existence. In addition to the swap line, Canada received credits from the IMF (\$300 million), the Bank of England (\$100 million) and the U.S. Export-Import Bank (\$400 million). The Bank of Canada immediately drew down the entire amount of the swap line and used the proceeds to defend the newly established parity. The drawing had an initial maturity of 26 September 1962, but the Bank of Canada renewed it for another three months. Financial flows into Canada had resumed by fall 1962, enabling Canada to repay the swap by year's end.

Despite the success of the Canadian operation, the System feared that the existing of temporary dollar liquidity through the swap lines might actually discourage foreign central banks from holding additional dollar balances, and indeed this seems to have happened. "Of the eleven countries with which the System has concluded swap arrangements, five (Belgium, France, Netherlands, Switzerland, the United Kingdom) only hold necessary working balances in official dollar balances. Among the others, Germany has cut its dollar holdings in half since the end of 1961, and Austria and Canada have kept their dollar holdings at about their 1961 levels. Only Italy, Japan and Sweden have substantially increased their official dollar holdings, and only in the case of Italy has this behavior been clearly attributable to the cover given by inter-official transactions.” (Board of Governors 21 March 1966, p. 31).

\section{Other uses}

The System established the second swap line-in addition to its Swiss franc line-with the BIS in 1965 to provide that bank with a means of acquiring temporary cash for routine 
transactions and to provide the System with access to additional foreign currencies. Previously the BIS had borrowed against gold that it held at the Federal Reserve Bank of New York. The System soon began using this swap line to supply funds to the Eurodollar market during times of strain when high Eurodollar rates would draw funds from the United States (Task Force Paper $\# 9,1990$ p. 12). The System asked the BIS to draw dollars on its non-Swiss franc swap line and to place the funds in the Eurodollar market. ${ }^{50}$ Previously, the System had asked foreign central banks to place dollar balances in the Eurodollar market during times of stress, particularly if the stress threatened to affect the foreign-exchange market. The System sometimes provided forward cover to facilitate such operations (MacLaury 1969, p.10). These placements became fairly routine, but often were insufficient to the task. The System intended the BIS operations as a supplemental arrangement. The Federal Reserve chiefly undertook BIS interventions under two circumstances: a spike in Eurodollar interest rates and downward pressure on the British pound (MacLaury 1969, p.12). Almost all such drawings were repaid within a month, either at, or prior to, their maturity date. The only exception occurred in a November 1967 drawing that extended for two months. After England, the BIS was the heaviest drawer on the U.S. swap lines, accounting for nearly 15\% of the drawing between 1962 and 1971.

\section{Sterilization.}

Swap drawings have the potential to affect U.S. bank reserves, depending on what the Federal Reserve does with the foreign currency that it receives - the Desk can buy dollars or hold and invest the funds - and what the foreign central bank does with the correspond dollarsit can buy foreign exchange, buy Treasury securities, hold a deposit at the Federal Reserve or place the funds in the Eurodollar market. In any case, however, the Federal Reserve can easily sterilize the transaction to any extent necessary. The Manager of the domestic desk in determining the appropriate amount of open-market operations to undertake on a particular day regularly took account of changes in foreign accounts at the Federal Reserve, changes in Treasury cash balances, changes in float, and changes in currency in circulation. Many of these can change following a swap drawing. In addition, close communications between central banks and with the Bank for International Settlements generally kept the desk appraised of any prospective swap drawing and aware of the anticipated use of the funds. At times the System has requested a particular use of the dollars from a swap drawing that it initiated. The desk's ability to sterilize was further enhanced because the value date of a swap drawing occurs two business days after the transaction date. McLaury (1969, p. 9) summarized the System's review of sterilization:

"In practice, the size of foreign drawings, large as they have been at times, has not been more than the domestic trading desk could offset-for the most part immediately - through open market operations. So long as the availability of the swap line is unconditional, the reserve consequences of foreign drawings are one of the operating factors that the Manager for domestic operations has to take into account in determining the size or direction of his own operations in any given day or week. They thus fall in the category of changes in Treasury cash balances, changes in float, and changes in currency in circulation.” (McLaury 1969, p. 9)

The effect is no different than the normal problems that the Desk faces because the dollar is a reserve and vehicle currency. 


\section{Spot market operations}

Spot market interventions played a comparatively minor part of U.S. exchange market operations between 1962 and 1971. The Federal Reserve and the U.S. Treasury generally did not regard spot market intervention as an effective means of preventing a persistent run on the U.S. monetary gold stock - the key U.S. objective. ${ }^{51}$ At best, spot market interventions might contribute tangentially to this objective. In addition, the Board feared that spot market interventions, if they successfully alter one exchange rate, might create a "broad range" of arbitrage incentives through other currencies, requiring simultaneous interventions across a broad swath of currencies (Board of Governors 21 March 1966 p.16). Consequently, the onus of spot market intervention stayed with foreign monetary authorities who established par values for their currencies in terms of the dollar.

Although spot market transactions did not directly forestall a drain on the U.S. monetary gold stock, U.S. authorities occasionally intervened to calm developments that, if left unchecked, might grow to threaten the existing parity structure. The most notable occasion occurred immediately following President Kennedy's assassination on 22 November 1963. At this time, trading in the New York market essentially stopped. To prevent panic selling, which seemed to afflict the stock market at the time, the Foreign Exchange Desk of the Federal Reserve Bank of New York (FRBNY) placed large orders to sell all major currencies at the exchange rates that existed just prior to the assassination. By the close of business, the Desk had sold \$23.5 million equivalent German marks, British pounds, Netherlands guilders, Canadian dollars, and Swiss francs. On that same day, the Bank of Canada bought $\$ 24.5$ million to support the dollar against its Canadian counterpart. (The System then acquired \$14 million from the Bank of Canada through its swap arrangement.) The European markets were closed at the time of the assassination. When they reopened, foreign central banks intervened in their spot markets, but by then, markets had settled down.

Similarly, news of the Cuban missile crisis on 22 October 1962 generated large financial flows out of dollars and into Continental currencies, especially Swiss francs. If left unchecked, the Desk feared, these financial flows might raise doubts about the structure of the exchange rates. Moreover, by placing unwanted dollars in the Swiss National Bank, they contribute to a potential drain on the U.S. gold stock. The Federal Reserve System responded by selling \$8 million equivalent francs into the Swiss spot market through the Swiss National Bank and \$2.3 million equivalent francs into the New York spot market. (The Swiss National Bank acquired \$50 million through intervention, and the System drew \$20 million equivalent Swiss francs through its swap line with the BIS on 31 October 1962 and bought dollars from the Swiss National Bank.) The System also sold $\$ 700$ thousand equivalent Dutch guilder in the New York spot market at the onset of the Cuban missile crisis.

Interventions during international crises were relatively isolated events. Much more common between 1962 and 1971 were U.S. efforts to moderate declines (lean against the wind) in the German mark-U.S. dollar rate through spot transactions. These operations ultimately sought to reduce expectations of a mark revaluation (see below). The System often sold German marks, which it acquired through the swap drawings, in the German market and after that market closed, in the New York market. ${ }^{52}$

On at least one occasion the System intervened to reinforce an exchange-rate movement. In September 1965, the Federal Reserve System, in conjunction with other foreign central banks, 
bought British pounds in the spot markets. At the time, speculators held short positions, which they needed to cover and were consequently buying British pounds. By also buying sterling at successively higher quotes, the System hoped to reinforce the demand for sterling - to lean with the wind. Sterling began to appreciate.

To guard against the possibility that persistent spot market transactions might create market distortions, the FOMC's Guidelines to the Special Manager allow him to "purchase and sell authorized currencies at prevailing market rates without trying to establish rates that appear to be out of line with underlying market forces." Some opponents of intervention, for example, worried that interventions could actually encourage further speculative financial flow by signaling official concern about the seriousness of a situation.

\section{Forward Market Operations}

Beginning in 1964, the Federal Reserve undertook forward-market transactions-often in concert with the U.S. Treasury-with the private sector and with foreign central banks. The transactions sought to provide counterparties with cover and to influence the forward exchange rate (see Board of Governors 21 March 1966, pp. 24-29). As noted, the U.S. Treasury found forward transactions particularly successful in 1961.

The Federal Reserve System often sold foreign exchange forward as a means of provided forward cover to private individuals currently holding or expecting soon to acquire, dollar balances. Often this was undertaking in conjunction with a foreign central bank's spot market sale of dollars. Sometimes it was undertaking as part of a System "market swap," in which the System bought foreign exchange spot and sold it forward into the market. Lacking the cover that such System forward sales provided, these private individuals probably would have sold their dollar balances to their respective central banks, which in turn might have converted the additional dollar balances to gold. An example of this type of forward transaction occurred in late 1964 and early 1965, when tight monetary conditions attracted funds out of British pounds, through dollars and into Netherlands guilder. In December 1964 and January 1965, the System and the Exchange Stabilization Fund, in cooperation with the Netherlands Bank, sold \$98.6 million equivalent and $\$ 95.4$ million equivalent guilders, respectively, in the forward market. ${ }^{53}$ This gave private individuals holding dollars spot the ability to sell them forward at a know exchange rate.

According to a System analysis, these transactions were effective in holding down the accumulation of dollars at the Netherlands Bank over the 8 to 9 month period that they were in force (see Board of Governors 21 March 1966, p. 25). Nevertheless, the transactions left the System and the Treasury carrying currency exposures for five and eight months, respectively, and raised questions about what constituted a temporary intervention. As a rule normal Federal Reserve swaps drawings with central banks expire within 3 months and parties cannot roll them over for more than a year.

In a somewhat similar type of forward transaction, U.S. monetary authorities sometimes offered to "take over" forward commitments from foreign monetary authorities. In the fall of 1965, for example, Italian authorities were experiencing substantial dollar inflows that were creating excess liquidity in their banking system. In an effort to reduce liquidity and to shift these inflows forward, the Italian Exchange Offices (IEO) undertook swaps with Italian commercial banks. In these transactions, the IEO would sell dollars spot to commercial banks for lira, which the IEO would then use to buy dollars spot, and repurchase the lira forward. 
These so-called market swaps provided commercial banks with cover for their dollar exposures at a favorable rate. Moreover the IEO could roll over the market swaps if necessary until the conditions that created the inflow subsided.

Despite this maneuver, the IEO was under pressure to convert the dollars, which ultimately presented them with an exchange-risk exposure, into gold. In early 1965, the Treasury and, later, the System began to take technical responsibilities for the IEO swaps. ${ }^{54}$ The Treasury started acquiring commitments in March 1965 and these rose to $\$ 1.0$ billion equivalent by November 1965. The System — under a new authorization-acquired \$500 million in forward commitments with Italian banks in November 1965. The IEO agreed to acquire the contracts at their final maturity and assumed the normal exchange-rate risks. The United States, however, guaranteed Italian authorities against any losses associated with dollar devaluation. This preferential guarantee posed a dangerous precedent for the United States (see Board of Governors, 21 March 1966, p. 28-9).

Besides these two types of operations to provide cover, U.S. monetary authorities frequently undertook forward transactions in an attempt to influence the premium of foreign exchange and, thereby, to influence short-term financial flows. In 1964, for example, the forward discount of sterling narrowed, creating an opportunity for covered interest arbitrage. Funds began to move from New York to London. The System undertook a series of swaps with the market, buying sterling in the spot market and selling it forward. The operation apparently increased sterling's forward discount. These forward contracts, however, matured during a crisis in the sterling market, so that the System's eventual forward sterling sales conflicted with Bank of England's objectives (see Board of Governors, 21 March 1966, p. 26).

Although forward sales of foreign exchange typically left the System with an exposure, all System forward transactions between 1964 and 1971proved profitable (Coombs 1971, p.2). This largely stemmed from the nature of the operations under the Bretton Woods peg-rate system. The System typically undertook forward transactions only when the foreign currency was selling at a substantial premium over existing spot rates, which fluctuated with one percent of their central parity. "In most cases" the System only undertook forward operations when the forward rate exceeded the spot rate's ceiling as defined by the central parity (Coombs 1971, p. 2). Hence, the System was likely to profit provided that the foreign country did not revalue their currency. Most countries offered the System revaluation guarantees similar to those that existed under the swap lines. Sometimes the System held sufficient foreign exchange balances to cover the operations even without a revaluation clause. On some occasions, as with German marks in 1971, the System drew foreign exchange on the swap lines when it sold that same foreign exchange forward (Coombs 1976, p. 3). The swap drawing covered the forward commitment, while the revaluation clause covered the swap repayment. Effectively, then the revaluation clause extended to the forward commitment. On at least one occasion, to avoid supplying dollars to the Bundesbank, the System drew on the swap 90 days forward, a time consistent with a forward sale of German marks. The Bundesbank extended the revaluation clause to this “forward swap drawing (Coombs 1971, pp. 4-5).

\section{IMF Drawings}

The ability to draw foreign currencies from the International Monetary Fund provided the U.S. Treasury with an additional mechanism with which to temporarily forestall the drain on the U.S. gold stock. Countries that are members of the International Monetary Fund (IMF) can buy 
(borrower) foreign currencies for intervention purposes against deposits of their own currency at the Fund. The amount that any country can draw on the IMF (as well as its contributions to the Fund and its voting rights within the organization) depends on that country's quota subscription to the Fund. Countries initially paid $75 \%$ of their quotas in their domestic currency and $25 \%$ in either gold or dollars. In February 1965, the U. S. quota in the IMF amounted to $\$ 4.1$ billion or $26 \%$ of the total (Yeager 1966, p. 348).

The IMF placed certain restrictions on countries borrowing, although these restrictions were flexible. No members could borrow foreign currencies to such an extent that it increased the Fund's holdings of the borrower's currency in excess of $200 \%$ of that country's quota. Since each country already paid $75 \%$ of its quota to the Fund in its own currency, at most a country could incur foreign currency debts to the Fund of $125 \%$ of its quota. In addition, no member's borrowings in any twelve-month period may increase the Fund's holding of its currency by more than $25 \%$ of its quota. The rules implied that the Fund could not compel any country, for example, a surplus country, to supply additional amounts of its currency to the Fund, except in exchange for gold. Similarly, the IMF could not require a country to loan its currency to the Fund to finance emergency borrowings (see Yeager 1966).

The Fund structures its loan to emphasize that they are intend for temporary balance-ofpayments problems. The Fund charges interest on borrowings in proportion to their size and duration and has myriad rules regarding repayment. Generally, however, countries must repay loans within 3 to 5 years. In addition, regardless of the currency borrowed, all loans must be repaid in either gold or a convertible currency. Often loans are provided under stand-by agreements that are in force for specific negotiated periods of time. The United States, for example, negotiated a one-year stand-by agreement in July 1963, on which we did not draw until February 1964. Countries can immediately borrow their "gold-tranche," an amount equal to the gold portion of its quota (normally 25\%), and can borrow another $25 \%$ of its quota without much conditionality. Borrowings of additional amounts require members to undertake programs to restore balance of payments equilibrium.

Even though member states increased their quotas in 1959, the Fund's resources were not sufficient to meet a large international crisis, particularly a speculative attack on both the U.S. dollar and the British pound. The IMF, for example, lacked sufficient non-dollar, non-sterling funds to meet the United States notional right to borrow (James 1996, p. 162) On 2 October 1962, ten major industrial countries (G10) agreed to stand ready to loan the Fund their own currencies up to a total of $\$ 6$ billion equivalent for intervention purposes. ${ }^{55}$ The facility was known as the General Agreement to Borrow (GAB). Loans would be in accordance with IMF policies, but required the consent of the lending countries.

Between 1964 and 1968, the United States undertook two types of drawings from the IMF, although both ultimately sought to avoid a possible drain of the U.S. monetary gold stock. The first, often referred to as technical, stemmed from the reserve currency role of the dollars and from IMF rules governing how many dollars that it could hold in its portfolio. Most countries that borrowed from the IMF held their foreign-exchange reserves in dollars and repaid their IMF drawings in dollars. By 1963, however the IMF's dollar holdings had reached $75 \%$ of the U.S. quota, and IMF rules precluded borrowing countries from repaying in dollars. The U.S. policy makers feared that if these countries could not repay their IMF obligations in dollars, they would do so with gold purchased from the U.S. Treasury. To avoid this possibility, on 13 February 1964, the U.S. Treasury undertook the first in a series of foreign-currency drawing 
from the Fund. In the initial drawing, the Treasury acquired \$130.5 million equivalent German marks, French francs, and Italian lira. These currencies were sold to a wide range of, mostly developing, countries for dollars. The Treasury undertook a second, \$125 million equivalent drawing of German marks and French francs on 1 June 1964. Over the course of 1964, the Treasury made five such technical drawings in seven Continental European currencies, totaling \$525 million equivalent. All but \$75 million equivalent was disbursed. In 1965 and 1966, the United States made additional technical drawings from the IMF (Desk Report 1965, 1966).

The United States also drew foreign currencies from the IMF to finance more normal adjustment purposes. In 1965, many countries acquired dollars reserves that the System covered through the swap mechanism, but because of continuing pressures on dollar exchange rates, the prospect for repaying these swaps became slim. On 30 July 1965, the United States made a \$300 million equivalent, medium-term, multicurrency drawing on the IMF. The drawing consisted of: \$180 million equivalent Italian lira, \$40 million French francs, \$40 million Belgian francs, \$25 million Dutch guilders, and $\$ 15$ million Swedish kronor. The Treasury made the Belgian francs and most of the Italian lira available to the Federal Reserve to help retire outstanding System swap commitments. This was the first IMF drawing explicitly for the purpose of retiring System swap debts. The Treasury used the remainder of the drawing to absorb dollars at foreign central banks (Desk Report, 1966, p. 39). In August 1966, the Treasury borrowed \$250 million equivalent Italian lira from the Fund and sold the proceeds to the System to refund swap obligations with the Bank of Italy and with the BIS. Because the Fund was short of lira at the time of this drawing, the Fund borrowed lira from the Italian Government under the General Agreement to Borrow. This was the first time that the Fund borrowed foreign currencies under the GAB. In early March 1968, the United States drew \$200 million equivalent in foreign currencies under its gold tranche with the IMF and sold these currencies to the System to cover outstanding swap obligations.

\section{Roosa Bonds}

The Treasury often acquired foreign exchange to finance its intervention operations by issuing non-marketable foreign-currency-denominated securities to foreign central banks or foreign governments. By holding such securities instead of dollars, foreign central banks were covered against the possibility of a dollar depreciation. Prior to the fall of 1962, the Treasury offered short-term debt instruments - certificates of indebtedness - to foreign central banks and governments. In November 1962, the Treasury began issuing longer-term non-marketable securities to foreign central banks and governments, so-called Roosa bonds after Under Secretary of the Treasury, Robert Roosa. Initially the Roosa bonds were nonconvertible, but to make them more attractive to the legal and portfolio needs of foreign central banks they became convertible on short notices into redeemable claims (Yeagar 1966, p. 449). Often the Treasury sold the proceeds from Roosa bonds to the System, enabling the latter to retire outstanding swap debts. The U.S. Treasury had \$298 million worth of outstanding foreign currency denominated securities at the end of 1962. These consisted of Italian lira bonds (\$200 million) and Swiss franc bonds ( $\$ 98$ million). The total outstanding balance of all Roosa bonds would grow to \$1.7 billion by the end of 1972. Although the Treasury generally maintained a negative net open position prior to the late 1970s, the Treasury often attempted to cover the exposure associated with outstanding bonds. Its early operations in Italian lira afford an example.

In 1962, the U.S. Treasury issued a series of 3-month certificates denominated in Italian

lira totaling \$150 million equivalent, and used the proceeds to finance forward lira sales to Italian commercial banks. Later in the year, the Treasury issued \$200 million equivalent in 15-month 
lira-denominated Roosa bonds to retire the 3-month certificates and to drain unwanted dollars that the Bank of Italy held. In late 1963, when the lira came under downward pressure and the Bank of Italy wanted to augment its dollars reserves, the U.S. Treasury bought lira outright from the Bank of Italy. This purchase provided the Treasury with partial cover for their outstanding lira bonds.

In November 1963, Coombs asked the FOMC for permission to purchase foreign currency in which the Treasury had outstanding indebtedness-most immediately in Italian lira - at rates above par, if necessary, and to sell the currency forward to the Treasury to cover its outstanding indebtedness (FOMC Minutes 12 November 1963, pp. 5 - 9). With the spot purchase from the market and the forward sale to the Treasury at the same exchange rate, the System would be "warehousing foreign currencies without capital risk until they were needed by the Treasury, whose resources for this kind of operation were limited." (FOMC Minutes 12 November 1963 p.7) ${ }^{56}$ The lira that the System purchases and sold to the Treasury enabled the Treasury to redeem a maturing \$50 million lira bond and pre-pay the remaining \$150 million bonds outstanding.

\section{Three Case Studies}

Neither U.S. macroeconomic policy nor the dollar's unique reserve currency role within the Bretton Woods system contributed directly to the devaluations of the British pound and French franc in August 1969 or to the revaluation of the German mark in the following October. Theses cross rate adjustment problems stemmed from local developments-poor British macroeconomic policies, French social problems, and persistent German gains in competitiveness (see: Solomon 1982, p. 158). Nevertheless, changes in pound, franc and mark exchange rates posed a general threat to the Bretton Woods parity structure. The associated uncertainty created speculative financial flows that cause other central banks to accumulate unwanted dollar reserves and that affected other exchange rates and the gold market. U.S. operations in these markets amply illustrate the successes and failures of foreign-exchangemarket operations during the Bretton Woods era.

\section{The Devaluation of the U.K. Pound ${ }^{57}$}

In addition to protecting U.S. gold reserves and shoring up the dollar, U.S. intervention operations between 1962 and late 1967, aimed at providing support to the U.K. pound. At the time, the pound was the second most widely held reserve currency, but observers increasingly questioned the viability of pound's parity because the United Kingdom's competitive position had deteriorated since the war and its reserve position seemed low relative to its emerging balance-of-payments deficits (see Cairncross and Eichengreen, 2003). By 1963, the pound was subject to Triffin's paradox; the value of outstanding pound claims exceeded the United Kingdom's foreign-exchange reserves (Bordo, et al. 2010, p. 192). Despite being in fundamental disequilibrium, massive amounts of foreign assistance between 1962 and 1967 helped the United Kingdom to hide its low level of reserves and maintain the pound's peg. The peg eventually collapsed when foreign governments ended their rescue efforts.

The pound's weakness presented U.S. monetary authorities with two closely related problems. First, financial flows from United Kingdom to Europe moved through U.S. dollars, increasing dollar balances in European central banks and the prospects that these banks might convert the dollars into U.S. gold. Second, U.S. policy makers feared that if a sustained speculative run against the pound lead to its devaluation, other countries would quickly follow. 
Pressure would then shift against the dollar's official gold price and seriously undermine, if not destroy, the credibility of the Bretton Woods system.

After the Federal Reserve became actively involved in foreign-exchange operations in 1962, the pound experienced a series of speculative attacks. ${ }^{58}$ The first began after French President Charles de Gaulle rejected the United Kingdom's bid for membership in the European Common Market in late January 1963. The rejection quickly put downward pressure on the pound. Largely by fortunate circumstance, the Federal Reserve was buying \$5.6 million equivalent British pounds from the market to repay a January swap drawing when pressures against the pound started to build (see figures 9 and 10). ${ }^{59}$ The Bank of England also began intervening with the dollar proceeds of the same swap drawing, but the pound continued to depreciate and fell below par. In response, the U.S. Treasury entered the fray, purchasing \$8.4 million worth of pounds in the market on 29 March 1963 (Bulletin September 1963, p.1219).

The speculative outflow from the United Kingdom caused other European central banks to acquire dollars. Consequently, instead of drawing down addition dollars from its U.S. swap line to defend the pound, the United Kingdom negotiated \$250 million worth of short-term credits with continental European central banks to shore up its potential reserves (Bulletin September 1963, p. 1219). Britain negotiated these credits in early February, but did not make them public until April 1963. The announcement of the cooperation among central banks took much of the pressure off of the rate by signaling a rise in the potential cost of speculating on a pound devaluation. The pound soon rose above par.

With pressure on sterling waning, U.S. monetary authorities took opportunities to retire their outstanding swap debt, and in the bargain, to support the pound. On 19 May 1963, in a further move to raise the potential cost of speculation against sterling, the Federal Reserve announced an increase in its swap line with the Bank of England from \$50 million to \$500 million (Bulletin September 1963, p. 1220). In considering the ten-fold increase in the swap line with the Bank of England, one FOMC member feared-quite rightly, as we have already seenthat if the Bank of England drew on the swap lines to defend the pound, the dollars thus expended might show up as unwanted dollar reserves on the books of other central banks (FOMC Minutes 28 May 1963, p. 17). The generous swap lines with the Bank of England thus presented a prospective problem for the United States down the road.

In early 1964, the pound again came under pressure because of a deterioration in the British balance of payments, uncertainty about the timing and outcome of upcoming elections, and rumors of a possible revaluation of the German mark. Bank of England interventions, sometimes undertaken in concert with the Federal Reserve and the U.S. Treasury, increased markedly. On 30 June, the Bank of England drew \$15 million from the swap line with the Federal Reserve System, but quickly repaid the drawing in July when money market conditions provided the pound with a respite.

In July 1964, covered interest arbitrage conditions favored a movement of funds into London. To forestall financial outflows from New York, the System undertook a series of swap transactions with the market designed to increase the forward discount on U.K. pounds by buying pounds spot against dollars and simultaneously selling them forward. These market swaps amounted to $\$ 28$ million equivalent in July. In addition, the U.S. Treasury offered \$1 billion worth of Treasury bills on July 22 in an Operation Twist effort to raise short-term interest rates relative to long rates (Bulletin September 1964, p. 1123). Nevertheless, covered interest 
arbitrage conditions continued to favor placing funds in London, and the System undertook addition market swaps in New York totaling \$26.2 million equivalent in late August and early September (Bulletin March 1965, p. 379). Many of these forward sales would eventually come due when speculative pressures were weighing on the pound. The System then found itself making spot sales of pounds in a weak market.

In August, sterling started weakening relative to other European currencies and funds began to shift anew out of pounds into the Eurodollar market. Britain negotiated a \$1 billion standby credit with the IMF, and in September, British monetary authorities arranged a \$500 million multi-country series of swaps with several European central banks and the Bank of Canada. "By the end of September, the Bank of England had drawn \$200 million of the \$1 billion of [international] swap credits available.” (Solomon, 1982, p.87). (The \$1 billion credit line included the System's swap line.) The Bank of England embarked on a series of almost continuous swap drawings and repayments with the System that continued through August 1965.

Britain elected a Labour Party government on 16 October 1964 by a narrow margin. Although opinion within the government was divided, the Prime Minister and much of the cabinet opposed any devaluation of the pound (Cairncross and Eichengreen 2003). Nor would the Labour government deflate the economy. Prime Minister Harold Wilson preference for renationalizing industries and expanding the welfare state, instead, sent financial funds flowing out of the country (Cairncross and Eichengreen 2003).

Within ten days of taking office, the new Labour government announced measures to deal with the country's growing balance-of-payments problem. These include a 15\% import surcharge and export tax credits, which quickly resulted in threats of reprisals (Bulletin March 1965, p. 380). The market anticipated an increase in the bank rate, but this did not immediately materialize. Finally on 20 November 1964, following another postponement of an increase in the Bank of England's discount rate, a massive selling wave began. On that same day, England exhausted it credit line with the Bank of Canada and with the other European central banks and had drawn $\$ 350$ million from its swap line with the System (Coombs 1976, p. 114). On Monday, 23 November 1964, the Bank of England increased its bank rate from 5\% to 7\%, but with the market now anticipating a pound devaluation, selling pressures became especially heavy.

On 24 November 1964, a \$3 billion short-term credit package to back up sterling began to take shape (Coombs 1976, pp. 116 - 123). The FOMC approved a $\$ 250$ million increase in the swap arrangement with the Bank of England to $\$ 750$ million. The Bank of England had been drawing on its swap line since August, and had even sold \$50 million in gold to the U.S. Treasury. The Export-Import Bank-a frequent participant in U.S. exchange-market intervention efforts-authorized \$250 million in credit (Coombs 1976, p. 117). Ten other central banks and the BIS participated, creating a $\$ 2.5$ billion short-term credit facility. Although France grudgingly participated, President De Gaulle claimed it would be the last time (Solomon, 1982, p. 89). During late 1964 — and throughout much of 1965 — the Bank of England continued to draw on its swap line with the Federal Reserve and to make simultaneous repayments. In total, the Bank of England drew \$1.4 billion between June and December $1964{ }^{60}$ The multinational short-term credit lines facilitated the repayments. Eventually, United Kingdom made a $\$ 1$ billion multi-currency drawing from the IMF in December 1964 to help with repayments. 
By late 1964, the United Kingdom was borrowing from some creditors to repay others. The country had not addressed its fundamental underlying balance-of-payments problem. As Coombs (1976, p. 123) concluded: "In any event, the provision of $\$ 3$ billion of new credits to the Bank of England signally failed to generate a real recovery of confidence in sterling." Although the crisis atmosphere lightened, uncertainty about the United Kingdom's trade deficit and its economic policies left the pound under downward pressure throughout December. Heavy interventions - particularly in the forward market—continued (Coombs 1976, p. 123, Cairncross and Eichengreen, 2003, p. 171). The Bank of England sold an additional \$75 million in gold to the U.S. Treasury in December to acquire dollars for intervention.

Britain's balance-of-payments deficits persisted in 1965 as did speculative attacks against sterling and heavy intervention. On 25 May 1965, with reserves and credit lines nearly exhausted, the Bank of England again drew \$1.4 billion equivalent in foreign currencies from the IMF and Switzerland, and repaid $\$ 1.1$ billion equivalent in outstanding short-term credits. The Bank’s \$2 billion credit line with other central banks then terminated (Coombs 1976, p. 124.) The Bank of England increasingly found itself attempting to defend a parity that many market participants and even official observers viewed as untenable.

After a brief mid-year respite, pressure on sterling returned because of tightness in the Eurodollar market and because the Bank of England had lowered its discount rate. The Bank of England was again intervening in both spot and forward markets for sterling. These operations intensified in August following the release of unfavorable reserves figures. By August, the Bank of England had drawn the full $\$ 750$ million on the System's swap line. On 31 August 1965, the System and Treasury extended a special one-day \$140 million credit to the Bank of England that allowed the Bank to bolster its reserves on a single day for reporting purposes (FOMC Minutes 31 August 1965, p. 4). Henceforth, swaps would occasionally serve this function.

Following notification that the government obtained some wage and price controls, the market again settled down, but the pound remained susceptible to downward pressure. British reserves were now very low, and existing short-term credit facilities with the United States and with the IMF were fully drawn. Britain entered into new credit arrangements totaling $\$ 600$ million with Canada, Japan, and the key European central banks. ${ }^{61}$ France did not participate. For its part, the United States agreed to buy $\$ 400$ million worth of pounds either on a guaranteed basis, which meant that in the event of a sterling devaluation the Bank of England would repurchase the sterling at the initial exchange rate, or otherwise on covered basis (Coombs 1976, 126-127, FOMC Minutes 8 September 1965 pp. 1-6). The announcement was made on 10 September 1965 at the opening of the New York market. The Bank of England in concert with U.S. monetary authorities immediately began purchasing sterling in New York "on a substantial scale and at progressively higher rates so as to convince the market of the determination and power of the central banks in support of sterling.” (Desk Report 1965, p. 13). The Desk operated directly with the market, not through the brokers' market with a commercial bank as its agent, as typically had been the case (Coombs 1976, p.128). ${ }^{62}$ The System purchased $\$ 21.5$ million worth of pounds on a "guaranteed basis." The pound rose above par, and Coombs (1976, pp. 129 \& 131) viewed the operation as a successful "bear squeeze." The bears did not die, they just hibernated for a while.

The enlarged international credit facility and a fortuitous improvement in Britain's balance-of-payments data checked the 1965 crisis. The Bank of England repaid \$275 million of its swap debts to the System in October and November. By year's end, the Bank of England had 
liquidated $\$ 760$ million of its forward market commitments and \$415 million of short-term obligations to United States. In addition, the Bank managed to increase its official reserves (Bulletin March 1966, p. 321). Nevertheless, U.K. fundamentals remained shaky.

When the international credit lines came up for renewal in March 1966, the foreign central banks, which had lost faith in the United Kingdom's willingness to make fundamental adjustments, placed restrictions on their use (see Coombs 1976, pp. 132 - 133). By then sterlingarea governments were approaching the Bank of England, looking to convert their foreigncurrency reserves out of sterling. The central banks that had participated in the September 1965 credit lines were willing to offer credits against the conversion of outstanding sterling reserve balances that foreign governments held, but not against continuing British balance-of-payments deficits. Moreover, the United Kingdom's drawings at any one time were not to exceed the amount of credits that the country still had available with the IMF. Essentially, the countries wanted an IMF backstop. At best, this was an insincere vote of confidence in the pound's prospects. The United States did not participate directly, but allowed the Bank of England to earmark a portion of the current U.S. credit lines to finance reserve losses attributable to the conversion of sterling balances. ${ }^{63}$

In February 1966, the pound again fell below par, prompting renewed Bank of England intervention in the spot and forward markets. By April, the System and the Treasury joined in, often covering their portion through simultaneous forward sales to the Bank of England. Pressure on sterling intensified following a British seamen's strike in mid-May, tightening credit conditions in the Eurodollar market, and continued sharp declines in British reserves. U.S. intervention purchases of pounds in the last half of 1966 were exceptionally large.

On 20 July 1966, the British government announced a massive austerity program that included a wage freeze, restraints on prices and dividends, additional taxes, reduced travel allowances, and further curbs on public expenditures (Coombs 1976, p. 136). To signal confidence in the British program, the Federal Reserve and the Treasury made huge spot purchases of sterling totaling \$55.1 million equivalent and \$89.6 million equivalent, respectively, in June and July. (During the same month, however, the System and Treasury delivered \$66.6 million worth pounds sold on a previous forward contract!) In addition, the Bank of England made a very large $\$ 100$ million swap drawing during the last statement week of July, bringing its entirely monthly drawing to $\$ 300$ million. "In order that the System’s weekly statement would not reflect too large an increase in its 'other assets,' the System at the end of its statement week of July 27 swapped \$88.2 million pounds for one day with the U.S. Treasury.” (Desk Report, 1967, p. 10) The System now sought to hide the magnitude of its sterling operations. Heavy interventions continued throughout the summer.

Although pressure on sterling began to subside in late summer, the situation remained critical. The prospects of once again getting the key central banks to provide the United Kingdom with credits to support sterling were now nil (Coombs 1976, p. 138 - 142). Consequently, the United States shouldered much of the burden. ${ }^{64}$ On September 13, the Federal Reserve announced a substantial increase, from $\$ 2.8$ billion to $\$ 4.5$ billion, in its swap facility. The swap-line extensions included an $80 \%$ increase in the System's line with Bank of England from $\$ 750$ to $\$ 1,350$ million. Coombs (1976, p. 141) described increases in the other swap lines as a "counterbalance," a necessary part of the sterling — and dollar — defense. If the pound came under speculative attack, the dollars expended to support sterling very likely would end up in the 
portfolios of other central banks. The System might then need to provide these banks with cover through swap drawings to protect U.S. gold reserves.

During the second half of September 1966, following the announced hike in the swap lines, demand for sterling increased as dealers sought to cover forward sales and to cover short positions. The Bank of England began buying dollars at each opportunity to rebuild reserves. The Desk undertook market swaps totaling \$36.3 million in November and \$51.6 million in December, with the proceeds split evenly between the System's and Treasury's accounts. Britain posted its first post-war trade surplus in November 1966, further alleviating strains of sterling. For the year as a whole, British reserves actually increased.

In early 1967, interest-rate differentials favoring pound-denominated assets continued to attract a financial inflow to Britain, despite that nation's weak trade performance. With its accumulated dollar reserves, British authorities by the end of March were able to repay its \$510 million obligation to United States outstanding at the end of 1966, including \$350 million in swap obligations with the Federal Reserve, \$50 million in special overnight credits from the System, and \$130 million in special over-night credits with the U.S. Treasury. In addition, the Bank of England repurchased \$33 million equivalent sterling from the Federal Reserve and a substantial sum from the U.S. Treasury. This reduced the Federal Reserve System holdings of sterling balances to \$101.8 million equivalent and the U.S. Treasury’s holdings to \$120.9 million equivalent. In addition, the Bank of England trimmed a November 1965 sterling-for-gold swap with the U.S. Treasury to $\$ 33.8$ million. As this swap unwound, the U.S. Treasury reduced a parallel gold for dollar swap with the Bundesbank. Full payment of these swaps was scheduled for June 1967 (Desk Report, 1968, p.10, fn.1). British authorities had also liquidated a substantial portion of outstanding credits from other monetary authorities.

This welcome break from speculation against sterling came to an end on 1 June 1967, when expectations of an imminent armed conflict in the Middle East caused a flight from sterling and a precautionary movement of funds out of the Eurodollar market. By 5 June, the Federal Reserve System and the U.S. Treasury had purchased on a swap basis nearly \$113 million equivalent sterling in the New York market, and the Bank for International Settlements drew \$143 million from the System's swap lines and placed the proceeds in the Eurodollar market to reduce interest-rate pressures. In early July, the Bank of England reported that it lost \$120.4 million in reserves during June (Bulletin March 1968, p. 272). This report further eroded confidence in the pound. The loss would have been larger had Bank of England not drawn on its swap line with the Federal Reserve, and on the 1966 international credit arrangements. In addition the Swiss National Bank and Swiss commercial banks shifted funds to the London market to compensate for funds moved into Switzerland during the Middle East hostilities (Desk Report 1968, p. 14, fn. 5). The closing of the Suez Canal together with a British dock-worker strike helped to worsen the British trade deficit.

On 19 October 1967, the Bank of England, hoping to reverse the financial outflows, raised its discount rate. In an effort to prevent a rise in the Eurodollar rates from nullifying the discount rate hike, the Federal Reserve drew on the swap line with the BIS, which then placed the dollar proceeds in the Eurodollar market (Bulletin, March 1968, p. 273). The Bank of England intervened heavily in both the spot and forward markets. The Treasury in concert with the Bank of England purchased spot sterling in an attempt to nudge the rate higher. By the end of October, the Treasury purchased \$47.1 million equivalent sterling. The Treasury now held \$194 million equivalent pounds under the Bank of England's guarantee against devaluation. 
Despite these actions, selling pressure only intensified, prompting the Bank of England to raise its discount rate again on 9 November 1967.

On Thursday, 16 November 1967, Chancellor Callaghan, responding to questions from Parliament, refused to either confirm or deny rumors of plans for a massive sterling bailout, and prompted an unprecedented rush out of sterling the next day. The Bank of England lost more than \$1 billion in a single day (FOMC Minutes 27 November 1967, p. 8). On Saturday, 18 November 1967, the British government devalued sterling 14.3\% to \$2.40. The Bank of England raised its discount rate to $8 \%$ (the highest level in 58 years), placed curbs on consumer installment credit, and asked commercial banks to channel credit toward exports. In addition, the government announced plans to cut public spending and to raise the corporate income tax (Bulletin March 1968, pp. 273-274).

Contrary to the expectations of U.S. monetary officials, no other major industrialized country followed the British devaluation. Instead, they made more than $\$ 1.5$ billion in new short-term credits available to defend the new parity, and the IMF established a new $\$ 1.4$ billion standby facility. The Federal Reserve System and the U.S. Treasury contributed $\$ 500$ million to this new facility (Desk Report 1968, p. 19).

The pound initially traded well above its new parity, but by the end of 1967, it weakened on news of continuing British trade deficits and because of speculative gold purchases. On 8 December 1967, the Bank of England purchased sterling when the rate moved below $\$ 2.41$ (FOMC Minutes 12 December 1967, p. 5). By the end of 1967, the Bank of England had outstanding short-term commitments to the US totaling \$1.6 billion, and large commitments to other monetary authorities (Desk Report 1968, p.22).

During 1968 and 1969, the British pound generally remained under downward pressure resulting in fairly persistent reserve losses. The exchange market remained skeptical of the Labour Government's commitment to the austerity measures that accompanied the November 1967 devaluation. In addition, the devaluation imposed losses on the reserve positions of sterling area countries, and these countries sought to protect themselves from another devaluation by diversifying out the sterling. Concerns about the Gold Pool and the growing prospects of a mark revaluation or a franc devaluation heightened uncertainties about the long-term viability of the new sterling peg. Consequently, the Bank of England sought major credit lines both to fund continuing support operations and to meet commitments arising from outstanding forward contracts and previous credit lines. In 1968, England did receive additional international credits, bringing England's total credit facility to $\$ 4$ billion. The Federal Reserve System increased its swap line with the Bank of England by $\$ 500$ million to $\$ 2$ billion, and the U.S. Treasury increased the credit facility that it extended to the Bank of England in November 1967 from \$350 million to $\$ 550$ million (see figures $9 \& 10$ ). In view of the severe strains on the official reserves, the U.K. elected to defer the year-end payment of principal and interest on post-war loans from the U.S. and Canada. This was the fourth postponement and left three such deferment options remaining (Cairncross and Eichengreen 2003, pp. 193-4.)

The situation remained tenuous until late in 1969. The devaluation of the French franc on 8 August 1969 prompted heavy renewed selling pressure on the pound. The Bank of England drew on its swap line with the Federal Reserve in order to finance its support operations. Pressure on the pound continued until September, when balance of payments data show a surplus. Following the revaluation of the German mark, the pound began to strengthen, and the 
Bank of England acquired sufficient dollars to begin paying back its swap obligations. The pound trade just below parity and forward discounts narrowed. By December 1969, as Eurodollar rates dipped, the pound rose above par for the first time since April 1968. The Bank of England acquired dollars, which it used primarily to repay international credits. By early 1970, the Bank of England had fully liquidated its swap debt with the System, and made strides at reducing other outstanding credits. On 5 March 1970, the Bank of England cut its discount rate from 7.5 percent to 7 percent. The Bank of England continued to pay down its outstanding debts throughout 1970. By April, for the first time since May 1964, the United Kingdom was free of all official debt (Cairncross and Eichengreen 2003, p. 194). The new exchange rate held until Bretton Woods ended.

\section{The Gold Pool}

Although the British devaluation did not lead to speculative attacks on other currencies, it did heighten speculative pressures in the London gold market. By March 1968, the Gold Pool disintegrated and a two-tier system of official and private gold prices replaced it.

After the United Kingdom reopened the London gold market in 1954, it rapidly reemerged as the largest, most important free market for gold in the world, and its daily fixing price became a barometer of confidence in the Bretton Woods (Bank of England, 1964). Sufficiently large deviation between the London market price and the official gold price afforded central banks the potential for profitable arbitrage. The lower arbitrage point- the price at which buying gold in London and selling it to the U.S. Treasury became advantageous-was approximately \$34.80 per ounce. This equaled the official \$35.00 per ounce less Treasury charges and shipping costs. The upper arbitrage point - the price at which buying gold at the official price in New York and selling it in the London market became profitable-was roughly \$35.20, the official price plus the Treasury fees and shipping costs. ${ }^{65}$ By and large, however, before 1965, the annual inflow of gold from new production and Russian sales typically accommodated private industrial, speculative, and official demands for gold, and if the London price deviated from the official price, the Bank of England could easily intervene to contain it within the arbitrage points (Bulletin March 1964 pp. 304). "By and large” here being the operative words.

This tranquility first started to fade as the U.S. Presidential election approach in 1960. On 20 October 1960, the London gold price temporarily peaked at approximately \$40 per ounce. This price spike followed a brief shortfall in gold supplies and rise in speculative demand associated with uncertainty about the Kennedy administration's commitment to the official gold price. Speculators believed that the Kennedy administration would pursue easier, inflation-prone policies that would worsen the U.S. balance-of-payments deficit and ultimately lead to a dollar devaluation. In response, the Bank of England acted to stabilize the market, with the support of the U.S. Treasury's gold stock, and it drove the price down to $\$ 35.60$ by the end of the year (Coombs 1976, p. 57). The price of gold stabilized at approximately \$35.08 by March 1961, following Kennedy's pledge to maintain the dollar's convertibility, and in the second quarter of 1961, a series of fortuitous, but short-lived, events that added to the supply of gold in the London market. These included Russian sales, Eisenhower's limitation on private U.S. citizens' overseas gold holdings, and British gold sales following the German and Dutch revaluations. Still, events in October 1961 "badly jolted” confidence in the dollar, and central banks “...could no longer forego the privilege [of converting dollars to gold] without exposing themselves to charges of 
imprudent management of the national reserves entrusted to their safekeeping." (Coombs 1976, p. 57)

Towards the end of 1961, however, South Africa and Canada reduced supplies to the market as they sought to build up their own reserves. Consequently, when the Berlin crisis unfolded, gold in London quickly began trading around the arbitrage point, \$35.20 per ounce. European central banks, concerned for the viability of the Bretton Woods system, refrained from buying U.S. gold and selling it in London, but as demand from other central banks and from the private sector grew, the situation became extremely tenuous. Concerted action seemed necessary. The Gold Pool was the result.

The Gold Pool developed as a gentleman's agreement following the 1960 price spike in the London market (Bank of England, 1964, p. 18). After a long period of informal discussions, mostly at the Basle meetings of central banks, the United States in October 1961 proposed the formation of an informal sales consortium to limit gold-price increases stemming from political crises or speculative activity. The governments of Belgium, France, Italy, the Netherlands, Switzerland, Western Germany, and the United Kingdom accepted the proposal and formed the Gold Pool. The initial subscription amounted to $\$ 270$ million worth of gold. The Bank of England acted as the consortium's agent in London and determined the appropriate amount of any sales. The United States, operating through the Federal Reserve Bank of New York, would match the gold sales of the other participating central banks, hence 50\% of all Gold Pool sales involved U.S. gold. The other central banks contracted to take set proportions of any gold sales up to their subscriptions. In addition, they agreed not to buy gold on the London market or from other sources, and they agreed not to convert any excess dollars that they received from such sales quickly into U.S. gold. In November 1961, the Gold Pool undertook a trial run, selling a moderate amount of gold in the London. When prices permitted, the Gold Pool repurchased this initial amount of gold and by the end of February 1962, redistributed it to the pool's participants. The operations went smoothly.

In early 1962, however, gold prices began to fall, and following a proposal by the United States, the pool began to purchase gold in the London market when the price approached the London gold export price. Now, instead of operating independently, the eight member nations bought gold in concert through the Gold pool. By late spring 1962, the Gold Pool had purchased \$80 million worth of gold (Bulletin March 1964, p. 306).

Even before the $\$ 80$ million could be distributed, a decline in U.S. stock prices and speculative flight from Canadian dollars again pushed gold prices up. By mid July 1962, the Gold Pool had used up its accumulated surplus, and by September 1962, the Pool had sold a net \$50 million worth of gold to the market. The Cuban Missile crisis in October 1962 resulted in record demands for gold, but substantial sales from the Pool helped keep the price below \$35.20. Subsequently, Russian gold sales helped drive the price down so that by the end of 1962, the pool had recovered all of its net gold sales.

During 1963 and most of 1964, gold prices remained fairly stable. Speculative demand seemed to diminish, new production increased, and Russia sold gold to the market and to the Gold Pool. In both years, Gold Pool acquired and distributed to its members $\$ 600$ million in gold (Bulletin March 1964, p. 307; Bulletin March 1965, p. 389).

Up to this date, the Gold Pool generally functioned as a successful stabilizing speculator might: buying low and selling high around what appeared to be a sustainable official price. By 
late 1964, however, the situation began to change, and it would only worsen hereafter in accordance with Triffin's paradox. ${ }^{66}$ In 1965, international tensions, stemming primarily from uncertainty about viability of sterling's parity, from France's decision to accelerate the conversion of its dollar reserves into gold, and from that country's public criticisms of the Bretton Woods system, resulted in a very heavy speculative demand for gold. In addition, Communist China bought large quantities of gold during much of the year. Even though sales from South Africa ran above normal, private demand absorb almost all of this, and the Gold Pool found its resources dwindling as it struggled to keep the gold price below \$35.20. At one point, early in the year, the Gold Pool operated with a \$50 million gold deficit, which the Bank of England financed out of its own reserves (FOMC, Minutes, 11 February 1965, p. 6). Participants agreed to continue selling gold, and by June, the Gold Pool had a deficit of \$170 million (FOMC, Minutes 15 June 1965 p. 2). Nevertheless, with a good amount of "sheer luck," the Pool recouped its losses by the end of 1965 (Coombs 1976, p. 153).

Even though the Gold Pool was able to replenish reserves from time to time through supplies from South Africa or Russia, or through additional member contributions, demand generally continued to outpace supply through 1966. As American policy makers feared, demand for gold had becoming increasing tied to expectations about British sterling and, by extension, to the viability of the official gold price. Moreover, the French government, as Coombs noted, seemed intentionally to hasten the system's demise: “The French Government continued to harass the market with a succession of announcements designed to cast doubt on the official \$35 price. The latest French move in that campaign, announced on January 29, was to internationalize the hitherto domestic French gold market. Those new measures now permitted French residents to buy gold on the London market and would encourage the growth of French gold custody business for nonresidents. ... [T]he French seemed to have deliberately put themselves on a collision course with U.S. policy...” (FOMC, Minutes 7 February 1967 p. 3).

Gold pool losses increased after 5 June 1967 outbreak of hostilities in the Middle East, requiring participating countries to contribute additional reserves to the pool, yet again. France, however, now balked at making a further commitment and withdrew, and the U.S. agreed to pick up their share. Other participating countries, notably Belgium and Italy, were losing confidence in the Gold Pool's viability and participants began to press the United States for a longer-term, fundamental solution to the problem.

The gold situation only worsened as the speculative attack on sterling continued. At the 14 November 1967 FOMC meeting, Coombs predicted that the Gold Pool would post a \$600 million to \$700 million deficit for all 1967 (FOMC Minutes 14 November 1967, p. 3). Since September 1966, the member countries had made eight contribution, totaling \$670 million in gold to the pool, compared with initial contribution of $\$ 270$ million. The seventh contribution had been negotiated on 8 November and had been virtually exhausted two days later; an eighth contribution was negotiated over 11 and 12 November. (FOMC, Minutes November 14, 1967 p. 4)

Coombs expected that the British Government would devalue the pound by $10 \%$ to $15 \%$ over the coming weekend unless they obtained massive support in the form of medium term credits (FOMC, Minutes 14 November 1967, p.4). He feared that a British devaluation would result in a run on the gold, causing participants to withdraw from the Gold Pool. He expected that a financial flight from sterling would leave other European central banks with huge dollar 
inflows and add to the drain of U.S. monetary gold. As the U.S. Treasury lost gold, the market would lose confidence in the dollar.

Coombs predictions did not immediately come true. Following the devaluation, Gold Pool members contributed a cumulative \$1,370 million to the operation. The U.S. Air Force cooperated by airlifting gold from the United States to London. The Paris newspaper Le Monde, however, announced that the Bank of France had withdrawn from the pool and that two other central banks (those of Belgium and Italy) were about to do the same (FOMC, Minutes 27 November 1967 pp. 3 - 6).

Foreign central bank operations in the Gold Pool, however, were only contributing to their further accumulation of dollars. Increasingly Gold Pool participants believed that the United States should absorb those dollars through an IMF drawing, rather than swap lines, and should take steps to plug the ultimate source of the dollar glut, the U.S. balance of payments deficit, through monetary and fiscal policies (FOMC, Minutes 12 December 1967 pp. 17 - 19). The United States promised to intervene in defense of the dollar and to pay down any such foreign currency debts arising from these operations with drawings on the IMF (Coombs 1976, p. 171).

Speculative gold demand remained strong in early 1968, and on 17 March 1968 the London Gold Pool suspended operations. Between the devaluation of sterling (18 November 1967) and the closing of the London gold market (17 March 1968), the Gold Pool sold \$3 billion worth of gold in the London market (FOMC Minutes 2 April 1968, p. 4). "Of that total, the U.S. share amounted to $\$ 2.2$ billion; both Italy and Belgium had replenished their share of pool losses during March by buying gold from the U.S. Treasury.” (FOMC, Minutes 2 April 1968 p. 6)

The seven leading central banks agreed to replace the Gold Pool with a two-tier gold market. Ideally, the existing stock of gold presently held as official reserves would be sealed off from the market. Monetary authorities would continue to buy and sell gold among themselves at the official price of \$35 per ounce, but they would refrain from transacting in the private market. With the establishment of special drawing rights (SDRs), they viewed the existing stock of official gold as sufficient for balance-of-payments purposes. All gold presently in private hands and all newly produced gold would remain outside of official reserves. Hence, the private price of gold could deviate substantially from the official price, and would become a highly visible barometer of confidence in the dollar and in the Bretton Woods system. Ironically, once the pool dissolved, a large overhang of speculative gold reentered the market, holding the free market prices within \$37 to \$40 per ounce (FOMC, Minutes 2 April 1968 p. 7).

Most other central banks and governments around the world signaled a willingness to cooperate with the two-tiered gold system. Some, of course, might not adhere strictly if the private and official prices greatly diverged. If the private market price fell below the official price, private gold producers would probably pressure their government to buy gold at the official price. Ultimately, however, the success of the venture depended on the triumphant adoption of SDRs, which could supply a non-dollar reserve to satisfy future reserve needs, and on an improvement in the U.S. balance of payments position, which only could prevent a continued drain on U.S. monetary gold stocks (Solomon 29 March 1968). 


\section{The Devaluation of the French Franc}

Between 1962 and early 1968, France became increasingly reluctant to cooperate in defense of the dollar. This reluctance stemmed from that country's fundamental displeasure with the dollar's role in the Bretton Woods system. The French government had long favored a fixed exchange-rate system that relied more heavily on gold for adjustment than did the Bretton Woods system and that did not confer unconstrained status on a single reserve-currency (see Bordo, Simard, and White, 1994). As the provider of the reserve currency, the United States had sustained a balance-of-payments deficit, but—in accordance with Triffin's prediction - this made the system unstable. France realized this problem and believed that all countries should link their currencies directly to gold, not to the dollar, thereby making them potential reserve currencies, and that the United States should redeem dollars in gold (Coombs 1976, pp. 174 175).

France attempted leverage U.S. support for its preferred revisions to the international financial system by selling dollars back to the United States and sometimes by recommending an increase in the official price of gold. Between 1960 and 1968, France continued to increase the share of its official reserves held as gold, largely via dollar sales to the U.S. Treasury. These dollar sales accelerated between early 1965 and the ending of the Gold Pool. In 1965, for example, French purchases accounted for more than two-thirds of the Treasury's gold sales to foreign countries. After the pound's devaluation in November 1967, hints of French support for an increase in the official gold price kept downward pressures on the dollar (see Bordo, Simard, and White, 1994).

Between 1962 and collapse of the Gold Pool in March 1968, the Federal Reserve System only undertook three, brief, exploratory operations in French francs (see figure 11). As discussed above, in March 1962, the System established a \$50 million swap line with the Bank of France and drew $\$ 50$ million equivalent francs from that line largely to "test communications, investment procedures, and other operational arrangements." (Bulletin September 1962, p.1148). The System simply held these francs in its portfolio. After one renewal, the Federal Reserve liquidated the swap drawing on 12 August 1962. In May 1963, the System drew \$12.5 million equivalent French francs from the swap line and sold them for dollars in the Paris market. The System simultaneously covered this swap drawing by purchasing francs forward from the Bank of France. The Desk was attempting to alter the level of the French franc-dollar exchange rate in a market that was not exhibiting compelling evidence of disorderly conditions nor under imminent threat of a speculative run. The U.S. dollar had persistently traded at the lower parity band against the French franc, as large financial inflows contributed to a sizable French balanceof-payments surplus. The dollar rate, however, "showed no lasting sign of improvement." (Board of Governors, 1966, p. 21) The System undertook a final operation in October 1963 that it financed with a $\$ 9.0$ million equivalent franc swap drawing. These operations gave the Bank of France discretion to sell francs as agent for the System (Bulletin, March 1964, p. 303). "Again, however, the underlying strength of the franc prevailed in the market; the dollar returned to the floor;" and the System stopped intervening (see Board of Governors, 1966, p. 21). These operations were also covered through forward purchases of French francs, and the System liquidated the drawing in January $1964 .{ }^{67}$

Over this same time period, the Treasury acquired French francs in conjunction with IMF drawings and briefly from a \$25 million swap with the Bank of England in December 1964 (see figure 12). Generally, the Treasury held these French francs or sold them to third parties. In 
August 1965, however, the Treasury sold $\$ 40$ million equivalent francs that it received from an IMF drawing to the Bank of France in order to reduce French acquisitions of U.S. monetary gold.

France's position as a strong-currency, surplus country came to an abrupt end in May 1968, when unexpected student rioting and labor strikes produced heavy financial flows out of French francs and into stronger currencies, despite the closing of most French financial institutions. The franc, which traded well above par throughout most of the 1960s, weakened precipitously. The Bank of France, whose operations were hampered by the closure of domestic financial institutions, asked the Federal Reserve System and the Bank for International Settlements to support the franc in the New York and European markets, respectively, for its account (Bulletin September 1968, p. 728). By the end of the month, the French government imposed exchange controls on financial outflows and temporary import quotas. Export subsidies soon followed. In early June, President de Gaulle called for elections, which the Gaullists won.

Although the immediate political crisis began to subside in early June, the franc remained weak under fears that the Bank of France would accommodate the government's large wage concessions, thereby further eroding France's international competitiveness and forcing a franc devaluation. To finance a defense of the peg, the Bank of France-for the first time-drew the full \$100 million from its swap line with the Federal Reserve System in June 1968. In addition, France drew \$885 million from the International Monetary Fund and sold gold from its reserves, including $\$ 220$ million of gold to the U.S. Treasury. ${ }^{68}$ The Bank of France's net reserve losses amounted to \$307 million and \$203 million in May and June, respectively, but taking the various credits into consideration, the Federal Reserve estimated the total cost of supporting the franc over these two months at $\$ 1.5$ billion (Bulletin, September 1968, p. 729).

France undertook additional measures in July 1968 to shore up market confidence in the franc. Early in the month, the Bank of France raised its discount rate from $3 \frac{1}{2}$ percent to 5 percent and the French government tightened exchange controls and imposed new taxes. On 10 July 1968, the Federal Reserve System in concert with the central banks of Belgium, Germany, Italy, the Netherlands, and with the Bank for International Settlements, extended \$1.3 billion in additional credits to the Bank of France. For its part, the Federal Reserve increased its swap line by $\$ 600$ million to $\$ 700$ million (Bulletin September 1968, p. 729-730). During July, August and September 1968, Bank of France drew an additional \$390 million from its swap line with the System, and financed the repayment of a small portion (\$40 million) in August by selling \$80 million of gold to the U.S. Treasury (Bulletin March 1969, p. 218). Despite the show of international support, speculative pressure persisted, and the Bank of France continued to lose reserves in defense of the franc.

By the fall of 1968, growing rumors of an impending mark revaluation maintained speculation against the franc as some of the earlier credits were coming due. This forced the Bank of France into the awkward position of having to acquire dollars when the franc remained weak. In October, the Bank of France undertook dollar swaps with French commercial banks, simultaneously buying dollars spot and selling them forward. The Bank then used \$75 million of the proceeds from these market swaps to reduce its official swap debt with the Federal Reserve System and to repay other international credits (Desk Report 1969, p. 50).

Rumors of an imminent German mark revaluation intensified in November 1968, particularly after the Basle meeting of central bank governors, and encouraged huge movements 
of funds out of French francs and into German marks. The Bank of France sustained large reserve losses in support of the franc, which remained at its lower parity limit (Bulletin, September 1969, p. 706). In response, the Bank of France raised its discount rate 1 percentage point to 6 percent, tightened reserve requirements, and imposed credit controls on short-term bank lending. To keep the franc from breaching its floor value, the Bank of France intervened heavily during the first nineteen days of November 1968. In addition to drawing down its reserves, the Bank of France drew \$275 million on its swap line with the System and \$283 million from other international credits, and sold \$110 million in gold to the United States and \$140 million to other European countries (Desk Report, 1969, pp. 51-53). In all, the 7-month crisis had significantly drained French reserves (Coombs 1976, p. 182). On 20 November 1968, France closed the market in Paris, as the G10 nations convened in Bonn to discuss the current situation.

At the Bonn meeting, the G10 ministers persuaded France to devalue the franc by 11.1 percent, but following the Bonn conference, President de Gaulle surprised the exchange market, which widely anticipated the devaluation, by rejecting the notion (Solomon 1982, pp. 159-60). Instead, de Gaulle outlined a series of belt-tightening policies, including much stricter exchange controls. The G10 provided France with an additional \$2 billion in credits at the Bonn meeting. The United States' contribution consisted of a \$300 million increase in the System’s swap line with the Bank of France (now at $\$ 1.0$ billion) and a new $\$ 200$ million credit facility through the Exchange Stabilization Fund (Bulletin March 1969, p. 218).

Governors Brimmer and Maisel worried that if the Treasury provided credits to Bank of France through a swap mechanism and subsequently warehoused those francs with the Federal Reserve System, the System would in effect be financing the credit to France. Coombs said that he would resist warehousing French francs (Minutes, 26 November 1968, pp. 22-23).

Largely because of stringent exchange controls, the Bank of France gained reserves from late November 1968 and through January 1969, which it used to repay credits. ${ }^{69}$ The Bank of France reduced its outstanding swap commitments with the System by $\$ 220$ million and paid down international obligations.

Expectation of inflation and devaluation persisted, and by February 1969, reserve gains attributable to exchange controls were not sufficient to fully finance the franc support operations. The situation worsened in March and in April, on renewed labor unrest, and the Bank of France again started to lose reserves. To finance continued interventions, the Bank of France again drew $\$ 70$ million from its swap line in February and an additional \$155 million in March $1969 .^{70}$ The Bank also sold \$50 million in gold to the U.S. Treasury (Bulletin September 1969, p. 707).

President de Gaulle’s resignation on 28 April 1969 did not stem the reserve losses, which if continued at their current pace, would exhaust the country's reserves by year's end. Many no longer believed that the franc's parity was viable, despite a further tightening of monetary policy in mid-June and George Pompidou's solid election victory. In May as speculation on a mark revaluation intensified, francs sold forward, "with 3-month contracts quoted at discounts as wide as 32 per cent per annum before the forward market temporarily dried up completely.” (Bulletin September 1969, p. 707)

In May 1969, a deadline on swap credits again compounded the Bank of France's intervention operations. The Bank owed \$436 million in swap debts to the System, as well as funds from drawings on other European credit arrangements. To service these obligations, the 
Bank sold \$275 million in gold to the U.S. Treasury and drew the remaining \$105 million available under the Treasury’s swap arrangement (Bulletin September 1969, p. 708).

Facing the prospect that its reserve would soon run out, France devalued the franc 11.1 percent on 8 August 1969, and instituted addition fiscal measures, credit restraints, and price controls to back up the new parity. The country had lost $\$ 500$ million per month in reserves during the last half 1968 and \$300 million per month during the first half of 1969 (Bulletin September 1969, p. 708). The Bank of France also received additional international credits and applied for a standby credit of $\$ 985$ million with the IMF (Bulletin September 1969, p.708). Despite the devaluation, the franc remained under downward pressure, forcing the France to further tighten its monetary policy.

Speculative pressures on the franc only began to unwind following the mark revaluation in October, 1969. France's balance-of-payments position then began to shift from a large deficit to a surplus, and the franc moved from near its lower parity limit to near its ceiling. French authorities were able to repay $\$ 1.5$ billion in short-term international indebtedness, in part by drawing $\$ 985$ million from the IMF. In addition, the Bank of France removed some of its most restrictive exchange controls (Bulletin, September 1970, pp.701-703).

France continued to acquire reserves through 1971. Although the Bank of France eased monetary policy, French interest rates fell at a slower pace than U.S. interest rates and consequently, encouraged a financial inflow. France used the addition reserves to continue to pay down its short-term international indebtedness. On 9 August 1971, the Bank of France paid off its IMF debt (Bulletin March 1972, p. 246). Because France had to repay a portion of this debt in gold, that country bought $\$ 191$ million in gold from the U.S. Treasury.

\section{The Revaluation of the German Mark}

During the Bretton Woods period, Germany generally maintained a relative tight monetary policy, ran fairly persistent trade surpluses, and experienced inflows of dollar reserves. As a means of compensating the United States for the American troops deployed on its soil, Germany often refrained from converting dollars reserves into U.S. gold. To some extent, this agreement freed U.S. monetary authorities of the need to provide the Bundesbank with cover for excess dollar holdings. Nevertheless, the U.S. did undertake such cover operations from time to time with the U.S. Treasury often playing a leading role. Instead of generally providing cover via swap operations, U.S. operations often focused on influencing spot and forward mark-dollar exchange rates through direct interventions. Perhaps, the U.S. monetary adopted this approach to the mark because they generally believed that the mark was fundamentally undervalued. If so, the mark would tend to trade above its par value, making swap repayments very difficult since the FOMC's authorization precluded the Desk from buying currencies in the market above par.

To create an initial portfolio in early 1962-before the System established its \$50 million swap line with the Bundesbank - the Federal Reserve purchased \$32 million equivalent of German marks from the U.S. Treasury (see figures 13 and 14). On 20 June 1962, with the German mark trading above parity, the Federal Reserve System began selling marks spot in the New York market. Between 1962 and 1966, the Desk typically operated in the New York market after the European market had closed. Sometimes, however, the Desk assumed all or part of the Bundesbank's intervention purchases of dollars in the European market (Board 1966, p. 22). This relieved the Bundesbank from holding additional dollar reserves. In late July 1962, just as the Treasury began to intervene in concert with the System, the mark began to ease 
against the dollar and afforded U.S. monetary authorities with an opportunity to reconstitute their mark portfolios. At the end of September, the Federal Reserve and the U.S. Treasury held open positions in marks equal to $\$ 31.2$ million and $\$ 31.7$ million, respectively. ${ }^{71}$ The System had not drawn on its swap line.

During the first half of 1963, improvements in the German trade balance, long-term financial inflows, and relatively tight monetary policy exerted almost continuous buying pressure on the mark. Between early April and the end of July 1963, the Bundesbank and the Federal Reserve Bank of New York undertook fairly heavy coordinated interventions to stem the mark's appreciation. The System financed nearly all of its interventions from two swap drawings. In August, buying pressure on the German mark eased somewhat along with conditions in the German money market, but with the mark often trading above par, the Federal Reserve System was unable to acquire enough German marks from the market to fully repay its swap drawing. Although the German Bundesbank was willing to extend the swap line, the Federal Reserve turned to the U.S. Treasury. Accordingly the Treasury issued \$50 million equivalent in twoyear, mark-denominated bonds (Roosa bonds) to the Bundesbank and sold the proceeds to the Federal Reserve System. This was the first instance of a refunding of a System swap drawing through medium-term Treasury borrowing. Earlier in the year, however, the Treasury had assumed a role that the System would normally initiate and had sold \$200 million equivalent in two-year, mark-denominated bonds to the Bundesbank to acquire its excessive dollar holdings (Bulletin March 1963, p. 320). Over the next three months, when pressure on the mark eased, the System purchased marks off-market from central banks and from the German Defense Ministry, which needed dollars to purchase U.S. military equipment (Bulletin March 1964, p. 297). On 10 October 1963, with recent swap debt repaid, the Federal Reserve System increased its swap line with the Bundesbank to $\$ 250$ million.

In November 1963, short-term funds moved back into German marks, prompting the Federal Reserve to draw $\$ 70$ million equivalent marks from its swap line with the Bundesbank. The System used part of these funds to intervene in concert with the U.S. Treasury in the New York market, but in contrast to earlier episodes of dollar inflows to the Bundesbank, the System also used a portion of the proceeds from its swap drawing to cover excess dollar balances at the Bundesbank. Over 1963, foreign-exchange reserves in Germany-presumably all dollars_had sharply increased substantially. In January 1964, the German government, which needed additional dollars for the military expenditures, supplied the System with marks to repay its swap drawing in full by 9 January 1964.

In response to rumors of a mark revaluation, the Treasury-in concert with the Bundesbank - sold \$21 million equivalent marks 3-months forward. This was the Treasury's first outright forward sale since 1961. On 23 March 1964, Germany imposed a 25 percent withholding tax on nonresidents' interest income from German fixed-interest securities (Bulletin September 1964, p. 1124). This reduced long-term capital inflows and induced some liquidation of investments in German bonds. In addition, the Bundesbank undertook market swaps with German commercial banks (selling dollars spot and repurchasing them forward for delivery in 90 to 180 days) at preferential rates to encourage these banks to purchase of U.S. Treasury securities - a financial outflow. Market swaps would eventually prove problematic for the Bundesbank, because the commercial banks could sell the dollars thus acquired back into the market. The System used the respite that controls afford to buy marks and repay the swap drawings made early in March. In addition to purchases from the market, the System and the 
Treasury bought \$35 million and \$45 million equivalent marks, respectively, from the Bank of Italy, which the Bank of Italy had acquired through a drawing from the IMF (Desk Report February1965, p. 16; Bulletin September 1964, p. 1125).

Although pressure on the mark-dollar rate had subsided, in April 1964, the U.S. Treasury sold \$200 million equivalent mark-denominated bonds to the Bundesbank and used the proceeds to again buy excess dollar balances from the Bundesbank. ${ }^{72}$ The excess dollars resulted from a continuing financial flows out of Italy and into Germany in late 1963 and early 1964 that simultaneously put downward pressure of the Italian lira and upward pressure on the mark vis a vis the dollar. The Bank of Italy required dollar reserves to intervene in support of the lira. The U.S. Treasury quelled pressure on both currencies by repaying a $\$ 200$ million equivalent lira bond, which it issued in 1962, to the Bank of Italy. To do so, the Treasury purchase lira from the Bank of Italy with the dollars it acquired from the Bundesbank. In short, the Treasury financed a lira support operation with debt issued to the Bundesbank.

The mark came under renewed upward pressure in June and July, leading to further intervention. On 9 July 1964, the Bundesbank announced an increase in commercial bank reserve requirements effective August 1 (Bulletin September 1964, p. 1126). The Treasury sold additional mark-denominated bonds to the Bundesbank to absorb excess dollars. By the end of 1964, the U.S. Treasury had $\$ 678$ million equivalent in mark-denominated bonds outstanding. In December 1964, the System also drew \$50 million equivalent marks on the swap line to absorb dollar balances at the Bundesbank. Germany's need for dollars to finance military purchases again enabled the System to reverse this swap in January 1965.

From May 1965 through October 1965, German’s trade balance deteriorated and the mark began to trade below its parity. With pressure off of the German mark, the Federal Reserve System and the U.S. Treasury purchased German marks from central banks and from the market in order to strengthen their reserve positions and to pay down U.S. Treasury mark-denominated bonds. This was the first liquidation of the bonds since the Treasury issued them in 1963. At the end of 1965, the Treasury still had a total of \$602 million equivalent German mark denominated bonds outstanding.

The German balance-of-payments deficit that emerged in 1965 continued through the first five months of 1966, largely because higher Eurodollar rates attracted a short-term financial outflow from Germany. The mark generally traded below par and the Bundesbank intervened substantially. During 1965 and 1966, Germany’s foreign exchange balances declined. The Treasury took this opportunity to reduce its mark indebtedness further. During the first half of 1966, the Treasury purchased $\$ 325$ million marks. In part this was accomplished with the System’s help. The System purchased \$53 million equivalent marks from the market and European central banks between April and June and sold them to the U.S. Treasury. The Treasury reduced its mark-denominated indebtedness to \$350 million equivalent by the end of 1966.

In May 1966, the Bundesbank raised its discount rate (Bulletin September 1966, p. 1322). This hike, in conjunction with the renewed wave of sterling selling produced a financial flow into German marks that brought the spot rate to parity and resulted in the Bundesbank acquiring more reserves than it previously loss. Tight monetary conditions and upward pressures on the mark persisted into the autumn. Germany announced a cut in reserve requirements effective in December, but the Bundesbank continued to acquire dollar reserves. 
In December, the System used \$15 billion from its own balances and drew \$140 million equivalent marks from its swap line with the Bundesbank to purchase dollars from the Bundesbank. The System also sold nearly \$28 million equivalent marks outright and undertook a \$17.5 million equivalent swap transaction with the market involving a spot sale of German marks and a forward purchase. The Treasury, which was intent on trying to pay down outstanding mark obligations, did not participate in the December interventions.

In early 1967, the System acquired sufficient marks from the market and from central banks to repay its December swap drawing from the Bundesbank. Later in the year, however, the System bought marks in the market and drew on its swap line to add to its portfolio as a precaution. The System did not intervene again against German mark until November 1967. As the market became unsettled following the depreciation of the pound and as rumors of a mark appreciation began to circulate, demand for German marks increased. The Bundesbank acquired \$357 million in the spot market (Bulletin March 1968, pp. 277-278). The Bundesbank then undertook market swaps, selling dollars spot against forward purchases with German commercial banks to keep dollars in the market and to reduce a widening premium on forward marks. By November 30, the Bundesbank had outstanding market swaps totaling \$600 million (Bulletin March 1968, p. 278). On 30 November 1967, the System increased its swap line with the Bundesbank from $\$ 400$ million to $\$ 750$ million. In December 1967, the Federal Reserve drew $\$ 300$ million equivalent marks on that line and sold them to the Bundesbank for dollars. This official swap transaction provided the Bundesbank with cover for one-half of its outstanding swap commitments with German commercial banks (Bulletin March 1968, p. 278). In addition, as uncertainty about the official gold prices grew, the System sold \$7.3 million equivalent marks in the New York market. Late in December 1967, when dollars briefly flowed out of German, the Federal Reserve bought marks.

After the closing of the Gold Pool in March 1968, speculative financial flows into Germany increased and the Bundesbank quickly acquired \$800 million. The Bundesbank immediately offered most of these dollars to commercial banks on an attractive swap basis. This swap offering was intended to provide dollar liquidity to the Eurodollar market and thereby to take pressure off of the British pound. The Federal Reserve absorbed \$300 million through its swap line, thereby providing some cover for the forward leg of Bundesbank's swap transactions (Bulletin, September 1968, p. 731).

In May 1968, Bundesbank President Karl Blessing reiterated Germany’s intention not to convert dollars into gold. That same month, as unrest was erupting in France, the German mark came under downward pressure following an April increase in the Federal Reserve's discount rate. At the time, the Bundesbank had announced an easing in German monetary policy. The Federal Reserve used the opportunity afforded by the financial outflow from Germany to buy marks in the New York market and to repay its outstanding mark obligations. In May 1968, the Federal Reserve also purchased \$25.2 million equivalent marks from Canada, which had recently floated a bond in Germany, and in June the System acquired \$50 million equivalent marks from the Bundesbank when the latter sought to replenish dollar reserves following a sale of dollars to France. In late June, the System acquired an addition \$125 million equivalent marks from the U.S. Treasury, which had just issued special mark-denominated securities to German banks as part of an agreement with the Germany to absorb dollars associated with stationing troops there (Bulletin, September 1968, p. 732). By the end of August 1968, these mark acquisitions enabled the System to repay all of its swap obligations to the Bundesbank and to the BIS. In that same 
month, the Treasury issued the first of a new series of mark-denominated securities to the Bundesbank designed to absorb troop dollars in addition to the securities already issued to German commercial banks. ${ }^{73}$ By early September, the Treasury had outstanding nearly $\$ 1.1$ billion equivalent mark-denominated securities.

In late August 1968, however, rumors of a mark revaluation resurfaced. After permitting an unprecedented one-day appreciation of the mark to its ceiling, the Bundesbank acquired \$820 million as the Labor Day weekend approached, with half of that amount coming on Friday alone (Desk Report, 1969, p. 34). Between August 27 and September 6 the Bundesbank purchased $\$ 1.6$ billion (Bulletin March 1969, p.214). The Bundesbank also undertook market swaps to encourage German commercial banks to hold dollars. In cooperation with the Bundesbank, the Federal Reserve and the U.S. Treasury each sold \$17 million equivalent German marks forward in the New York market during August and early September, but despite the concerted actions to limit speculation, the Bundesbank acquired an additional \$840 million in the three days ending 6 September 1968.

Speculation dramatically intensified in November, after a brief respite in October. ${ }^{74}$ At the Basle Meeting, the central bank governors recommended a 7.5 percent revaluation of the mark (Solomon 1982, p. 2). Instead the Bundesbank intensified its intervention efforts, making very large dollar purchases (over \$1 billion in two days ending Friday, 15 November 1968 and $\$ 2$ billion since the beginning of the month) and undertaking approximately $\$ 1$ billion in swaps with German commercial banks (Desk Report, 1969, p. 37; Bulletin March 1969, p.215). Rather than invest the swap proceeds in interest earning assets, however, these commercial banks resold the now-covered dollars in the market, thereby negating the effects of the swap and leaving the Bundesbank with a forward obligation to sell marks. The Bundesbank responded by issuing swaps only to banks that used the proceeds to acquired U.S. Treasury securities, but it soon had to sell marks through outright forwards (Bulletin March 1969, pp. 215-16). German banks wanted outright cover for their dollar position; they did not want cover on a swap basis, which eventually had to be rolled and therefore left them with some exposure. Bundesbank forward mark sales in late November amounted to \$246 million equivalent (Bulletin March 1969, p. 216). The System drew \$111.3 million equivalent marks on its swap line with the Bundesbank and sold \$47 million equivalent marks spot in New York. With the remaining marks from the swap drawing as partial cover, the System also sold \$72 million equivalent marks forward in New York. In December, as the mark temporarily weakened, the System bought marks spot as additional cover for its forward position.

After acquire \$850 million over two days-November 18 and 19, 1968-the German authorities announce that they would not revalue the mark. ${ }^{75}$ They then undertook a faux revaluation by adjusting value-added tax rates to raise export prices and lower import prices (Solomon 1982, p. 158). In addition, the Bundesbank impose 100 percent reserve requirements on new foreign-owned mark deposits at German banks, reinforcing the previous ban against interest payments on such deposits (Bulletin, March 1969, p. 216).

These policies were sufficient to encourage a financial outflow by the end of November 1968, enabling the System to acquire, once again, sufficient marks to repay its swap drawings by January 1969. ${ }^{76}$ Nevertheless, in 1968, Germany had acquired a little more than \$1billion in foreign exchange reserves. In January, as the mark moved below par, the Bundesbank sold large amounts of dollars in the market and reduced the attractiveness of its swaps with commercial banks. Even larger sales of dollars continued in February and March. U.S. monetary authorities 
made heavy market purchases of German marks between December 1968 and March 1969. In addition to paying down its swap drawings, the System used the newly acquired marks to meet forward obligations as they matured, and to increase balances. In February, 1969, the Treasury, which also had been acquiring small amounts of marks from the market and from the Bundesbank, redeemed a \$50 million equivalent outstanding mark-denominated note.

The outflow of funds from Germany reversed itself in April 1969, when President de Gaulle's resignation heightened speculation of a French franc devaluation. Concurrent rumors that some members of the German cabinet favored an 8 to 10 percent mark revaluation as part of a multilateral exchange rate re-adjustment augmented the speculative flows into marks (Desk Report, 1970, p. 9). Moreover, a tightening of monetary and fiscal policies to combat growing inflationary forces only worsened Germany’s balance-of-payments situation (Desk Report, 1970, 9-10).

The mark rose sharply, forcing the Bundesbank to buy dollars late in April. Speculative flows became massive at the end of the month, so much so that in the three days prior to Friday, 2 May 1969, the Bundesbank acquired $\$ 860$ million (Bulletin September 1969, p.702). On May 7, the Bundesbank discontinued its swap operations, since commercial banks were now placing the funds into the Eurodollar market where they were recycled into the foreign exchange market and again converted into marks. On May 8, the Bundesbank received very heavy inflows of dollars, much of it in the New York market through the Federal Reserve Bank of New York. The Bundesbank then limited its support operations in the New York market to only DM 400 million, an amount that quickly proved inadequate. Although IMF rules oblige a country to defend its currency in its own market, a member country was not obliged to defend its currency in a foreign market. To assist in the defense of the mark, the U.S. Treasury sold \$106 million equivalent marks into the New York market. To undertake this defense operations, the U.S. Treasury acquired virtually all (\$165 million equivalent) of the System’s mark balances. The following day, speculation was equally intense, "the heaviest flow in international financial history.” (Bulletin September 1969, p. 703.)

“The speculative onslaught between the end of April and May 9 increased German monetary [international] reserves by some $\$ 4.1$ billion-including $\$ 2.5$ billion on May 8 and 9 alone-to a record level of $\$ 12.4$ billion.” (Bulletin September 1969, p. 703) After Germany emphatically dismissed revaluation rumors, speculation subsided. With inflationary pressures now emerging, Germany tightened fiscal and monetary policies. Absorbing domestic liquidity in this situation, however, could only encourage additional inflows. Revaluation now seemed a certainty; only the timing remained unclear.

Speculation intensified again as the September 28 election approached. The Bundesbank acquired increasing amounts of dollars, but was simultaneously selling dollars on a swap basis. Again the funds were spilling into the Eurodollar market. "[O]n September 18, after such sales had reached $\$ 0.7$ billion over a 10-day period, the [Bundesbank] raised its swap rate, thus bringing to a virtual halt the covered movements of German funds into the Euro-dollar market.” (Bulletin, March 1970, p. 230) A further tightening of monetary policy in mid-September only intensified the financial inflows. The Government closed the foreign exchange market for the two days prior to the elections and suspended official foreign-exchange operations. In New York, the mark traded above parity. When the election was inconclusive, the Bundesbank briefly returned to the market, took in $\$ 245$ million in the first hour and a half of trading, and then allowed the mark to float. The mark appreciated 71/4 percent by mid-October, with the 
Bundesbank gradually raising its buying rate to keep a floor just below the market rate (Desk Report, 1970, p. 20). The Federal Reserve also bought marks. The coalition government that took office on 21 October 1969, revalued the mark 9.3 percent on 24 October 1969, and eliminated the special taxes on exports and imports that created the faux revaluation of November 1968. "The revaluation was larger than had generally been anticipated, thus decisively removing the mark from the realm of speculation...” (Bulletin March 1970, p. 231)

The revaluation led to a severe outflow of funds from Germany, which depleted official reserves and drained liquidity. To stem the movement out of mark, the Bundesbank eliminated discriminatory reserve requirements on foreign deposits. The Bank also raised its Lombard rate, and in December 1969, German authorities removed the prohibition on paying interest of foreign-owned deposits. The Federal Reserve took advantage of the financial outflows to rebuild its depleted mark balances. In late October and November 1969, the System bought \$59.3 million equivalent marks. The U.S. Treasury activated revaluation clauses covering its markdenominated securities. This allowed the Treasury to purchase marks at a substantial discount either to hold in its depleted portfolio or to resell for a substantial profit. The Bundesbank had depleted most of its liquid dollar holdings. To recoup these, Germany sold mark-denominated U.S. Treasury securities back to the Treasury for dollars, sold \$500 million in gold to the U.S. Treasury, and drew \$1.1 billion in credits from the IMF (Bulletin March 1970, p. 232).

\section{Breakdown of Bretton Woods $1970-1973^{77}$}

Much of the exchange-market turmoil from 1967 through 1969 stemmed from the adjustment problems of individual currencies. While these raised uncertainties about the underlying Bretton Woods parity structure and created undesirable reshufflings of dollar reserves, they did not directly reflect problems with the dollar. Inflation in the United States, however, was accelerating, and the nature of the international financial problem was changing. By 1970, the market viewed exchange-market disorder as a dollar crisis and not, as was the case earlier, a problem of unsustainable cross rates (Solomon 1982, p. 182).

According to Coombs (1976, pp. 204 - 211), the Nixon administration, which came to office in January 1969, believed that our major trading partners were deliberately discriminating against the United States. Consequently, the administration adopted a practice of "benign neglect” about the growing balance-of-payments deficit and the United State's commitments under Bretton Woods. A subsequent U.S. focus on domestic growth and employment and the emergence of inflation flooded foreign economies with dollar reserves, put upward pressures on their currencies and price levels, and ultimately lead to the demise of the Bretton Woods system.

Closing the Gold Window 1970 - 1971

Despite some tightening in U.S. monetary policy, the U.S. inflation rate continued to accelerate through 1969, reaching nearly 6 percent by year's end. The on-set of a recession induced the Federal Reserve to again loosen monetary policy and to maintain an accommodative stance in 1970 and 1971 (figure 6). Interest rates in the United States fell, and as U.S. banks repaid earlier borrowings from foreign affiliates, so did Eurodollar rates. Many European countries, however, were tightening monetary policy to ward off inflationary pressures by 1969. Even when European countries lowered interest rates, as they eventually had to do, their movements typically lagged those in the United States during this period. This interest-rate pattern induced heavy financial flows out of dollar-denominated assets. Initially, much of the dollar reflow went to countries like the United Kingdom and France that needed to rebuild dollar 
reserve positions and to repay debts (Bulletin, September 1971, p. 783). The dollar reflows, however, quickly became problematic for countries like Germany, Italy, Belgium, the Netherlands, and Switzerland. Dollar inflows pushed their currencies to their upper parity limits vis-á-vis the dollar, forcing their central banks to intervene. In many cases, the acquisition of dollar reserves offset domestic monetary restraint programs designed to reduce inflationary pressures. Attempts to tighten policy further only aggravated the inflow of funds. By early 1971, as Coombs (1976, p. 212) notes, the process developed a self reinforcing aspect as “...overt speculation further swelled the torrent of dollars flowing to foreign markets."

By the summer of 1971, confidence in U.S. monetary policy was rapidly evaporating and a crisis atmosphere was emerging. Inflation in the United States remained around 4.4 percent, despite slow economic growth and a high unemployment rate. Moreover, the U.S. balance-ofpayments position continued to deteriorate. Expecting further revaluations, speculators began borrowing Eurodollar funds to buy foreign currencies (Bulletin, September 1971, p. 812). On 6 August 1971, a congressional subcommittee identified the dollar as overvalued and called for a realignment of currency rates, including a dollar devaluation. On that same day, the U.S. Treasury reported a loss of gold and reserves of $\$ 1$ billion, largely as Britain and France exchanged dollars to repay IMF debts. Over the next week, $\$ 3.7$ billion in gold and reserve assets moved abroad (Coombs 1976, p. 215). Gold moved to \$44 per ounce in London, and speculative flows out of dollars and into foreign central banks intensified. On 15 August 1971, President Nixon closed the gold window. Acting under the Economic Stabilization Act of 1970, he ordered a 90-day freeze on wages and prices and recommended new tax measures to stimulate investment and employment. He also introduced a temporary 10 percent surcharge on dutiable imports.

Although Chairman Burns told the FOMC that suspending the dollar's convertibility would be temporary, Charles Coombs appreciated the action's real significance: “[T]he decision to close the gold window had demolished with one stroke the Bretton Woods exchange rate system.” (FOMC Minutes, 24 August 1971, p. 27) The announcement surprised the major European governments, who closed their exchange markets and sought—unsuccessfully—a joint policy response to the U.S. measures (Bulletin, September 1971, p. 786). They reopened their markets on Monday, August 23, and although they formally adhered to their parities - with the exception of France - they suspended their commitments to defend them. Japan had initially attempted to defend its parity, and took in \$2 billion on 15 August 1971. With substantial inflows of dollars continuing, Japan suspended its official intervention on August 28. All of the major currency appreciated against the dollar during the next two months-except the fixed French commercial franc-as speculative flows continued. At the high end was the German mark, which rose 9.5 percent above its previous ceiling. At the low end was the French financial franc, which rose 1.7 percent (Bulletin, September 1971, p. 786). ${ }^{78}$

The foreign currencies appreciated despite heavy foreign interventions, and foreign central banks continued to accumulate large amounts of unwanted dollar reserves, which contributed to their inflationary pressures. As a consequence monetary authorities began to tighten controls on financial inflows. "The exchange rate structure thus emerging after August 15 was, in most instances, the product of controlled rather than free floating." (Bulletin, October 1971, p.786) Europeans and Latin American countries argued that the U.S. import surcharge was also distorting exchange-rate relationships (Solomon 1982, p. 189). They lodged a formal complaint with the GATT. 
In 1971 prior to the closing of gold window, the Federal Reserve frequently initiated large swap drawings to forestall foreign central banks from converting excessive dollars reserves into U.S. monetary gold. On 1 January 1971, the System had outstanding swap commitments of $\$ 810$ million. By July 1971, the System had reduced this to $\$ 605$ million often with the aid of U.S. Treasury sales of gold and SDR's, borrowings from the IMF, and the issuance of foreigncurrency denominated securities. As funds move rapidly abroad, the System then drew \$2.2 billion - with assurances of a Treasury backstop - to provide further cover to central bank through 13 August 1971 (Coombs 1976, p. 217 and Bulletin, September 1971, p. 787).

After 13 August 1971, the System made no further drawings on its swap lines. The System encountered difficulties in repaying outstanding swaps because most foreign central banks did not want the System buying their appreciating currencies in the market. They preferred to roll-over existing swaps, expecting that new parities would soon be established and a reversal of financial flows would follow (FOMC Minutes, 16 November 1971, p. 15; Bulletin, September 1971, p. 787). In contrast, the Belgian National Bank asked the System to repay a \$35 million swap drawing that had been outstanding for seven months. This required the System to purchase Belgian francs at a premium and to incur an overall loss of \$1.9 million on the transaction. The U.S. Treasury preferred the System's taking a loss on this transaction to financing the operation through official reserves (FOMC Minutes, 19 October 1971, p. 18). By 14 October 1971, the System had outstanding swap commitments of \$3.0 billion.

Despite this heavy use of swaps, the United States lost large amounts of official reserves to foreign central banks in 1971. "From January 1, through mid-August a total of $\$ 3.1$ billion in such assets was paid out, including \$864 million of gold, \$394 million of foreign exchange, \$480 million of SDR's, and \$1,362 million taken down against the U.S. IMF position.” (Bulletin, September 1971, p. 789) In addition, the Treasury issued \$582.7 million in new Swiss franc denominated securities between 1January 1971 and 13 October 1971 (Bulletin, September 1971, 789).

\section{First to Float: Canada}

Following the devaluation of sterling in November 1967, the Canadian dollar came under heavy speculative attack. The market feared that the recently announced U.S. restraints on financial flows might adversely affect U.S. direct investments into Canada and short-term financial flows between the two countries (Bulletin August 1968, p. 739). Canadian reserve losses were heavy in January and February 1968, causing Canadian monetary authorities to reinforce their position by drawing $\$ 250$ million on the $\$ 750$ million swap facility with the Federal Reserve and \$426 million from the IMF (Bulletin August 1968, p. 740). Canada also increased its discount rate.

Pressures on the Canadian dollar persisted and intensified in March 1968, as speculative funds moved out of Canadian dollars and into gold. Canada sought and received additional international credits amounting to $\$ 900$ million from the U.S. Export-Import Bank, the German Bundesbank, the Bank of Italy, and the Bank for International Settlements. These credits did not include the \$500 million still available to Canada through the Federal Reserve swap line, which the System subsequently increased to $\$ 1.0$ billion (Bulletin August 1968, p. 740). In addition, the U.S. exempted Canada completely from the restraints on financial flows that it imposed in the January 1968. For its part, Canada agreed to invest its dollar reserves-apart from working 
balances_-in U.S. Government securities (Bulletin August 1968, p. 740). Canada again raised its bank lending rate when the Federal Reserve Bank hiked the discount rate.

The situation, briefly improved in the spring of 1968, enabling Canada to acquire reserves and repay international credits. In 1969, however, the United States tightened monetary policy. High interest rates in the United States and in the Eurodollar market encouraged a financial outflow from Canada and prompted the Bank of Canada to tighten its monetary policy and its restrictions on financial outflows.

With the on-set of a recession in early1970, the United States eased monetary policy, and the financial tide quickly reversed. Strong inflows of both long-term and short-term funds now pushed the Canadian dollar to the top of its trading range. The Bank of Canada-as agent for the federal government - bought large amounts of U.S. dollars to keep the Canadian dollar within it parity range, adding unwanted domestic liquidity to the Canadian market at a time when the Bank of Canada was trying to contain inflationary pressures. Inflation was currently running at approximately 4 to 5 percent and wage settlements reached 9.1 percent (Powell 2005 p. 71, fn 90). Although the Bank of Canada favored a new par value with wider parity bands, the government rejected the idea out of a concern that it would provide only temporary relief and would not be credible. The government also considered asking the United States to rescind its Canadian exemption under the U.S. Interest Equalization Tax, but the exemption helped reduce the borrowing costs of provincial governments (Powell 2005, p. 72).

On Sunday, 31 May 1970, Finance Minister Benson announced that the Bank of Canada would no longer defend the upper limit for the Canadian dollar, effectively allowing it to appreciate. Benson intended to re-fix the exchange rate as soon as possible. The Bank of Canada intervened on June 1 when the Canadian market opened to smooth the increase in the rate. Over the following weeks, the Bank of Canada intervened to dampen the swings, especially excessive increases in the exchange rate (Bulletin September 1970, p. 695). The Canadian dollar, however, was now floating. ${ }^{79}$

Coombs viewed the Canadian float as a serious threat to the Bretton Woods system. He noted that the ability of central banks to defend their parities against speculative attacks was increasing "suspect." Nevertheless, "[u]ntil the Canadian decision to let their rate float, the market had not taken seriously official discussions of rate flexibility.” (FOMC Minutes, 23 June 1970 p.42) Reflecting his overall attitude towards floating rates, Coombs viewed financial flows under the Canadian float as destabilizing: “...the rise in the rate tended to be self-reinforcing in that it encouraged an increasing tendency to cover Canadian dollar commitments. Another factor in the market, starting toward the end of July, was the appearance of professional traders, mainly European banks, who would move in and out of the Canadian dollar within a single day to take advantage of the wide fluctuations in the rate, their actions clearly aggravating those fluctuations.” (Bulletin September 1970, p. 695) The early float, however, insulated the Canada dollar from much of the exchange-market chaos of 1971.

The German Mark Example.

Germany's experience in 1970 and 1971 provides the clearest example of the problem with fixed exchange rates when domestic and international objectives conflict. ${ }^{80}$ In the spring of 1970, the Bundesbank began to tighten monetary policy to counteract growing inflationary pressures. Germany's GNP deflator increased 7.3 percent in 1970 and 7.7 percent in 1971 (see IMF 1972, p. 7). With interest rates on dollar-denominated assets falling-the U.S. experienced 
a recession in 1970 - funds began to flow into Germany. The mark, which had been trading near its floor value ever since the October 1969 revaluation, began to rise sharply. By mid-May 1970 with the mark now trading at its upper limit, the Bundesbank began acquiring substantial amounts of dollars through its interventions. The floating of the Canadian dollar in June 1970 only added to speculative pressures against the mark. On 10 June 1970, the Bundesbank, in "the most hectic day of trading since the fall of 1969,” purchased \$640 million at the upper parity band, but the rate moved even higher that afternoon in New York after the close of business in Frankfurt (Bulletin September 1970, p. 697). During the whole of the second quarter of 1970, the Bundesbank acquired \$1.4 billion in reserves (Bulletin March 1971, pp. 189-207).

Germany next attempted to fine tune its monetary policy and to supplement it with other measures. In July 1970, the German government tightened fiscal policy. The Bundesbank cut its discount and Lombard rates hoping to take pressure off of market rates, but the bank also instituted heavy reserve requirements on bank liabilities. Although short-term rates fell briefly, they quickly turned around. The net effect was that inflows of reserves continued and in the third quarter of 1970, the Bundesbank acquired almost \$2.5 billion (Bulletin March 1971, p. 198). In late October 1970, the Bundesbank converted its reserve requirements into a form of capital controls by directing them to certain interest-arbitrage transactions and to dealings related to foreign borrowing. Continued pressure on the mark, however, forced the Bundesbank to lower its discount and Lombard rates again in early November 1970. Despite these maneuvers, funds continued to flow into Germany. In December, following a cut in the U.S. discount rate, the Bundesbank again lowered its official lending rates, and German interest rates fell more closely in line with Eurodollar interest rates. Nevertheless, in the fourth quarter of 1970, the Bundesbank acquired $\$ 2.3$ billion in reserves, and remained hampered in adopting an antiinflation policy stance.

Despite cuts in German interest rates, the spread vis-á-vis Eurodollar rates continued to attract funds into Germany during early 1971. The spot rate remained at, or near, the upper parity band and the Bundesbank continued to acquire dollars. "During the period February April 1971, German corporate borrowing abroad amounted to roughly $\$ 2.5$ billion, nearly equivalent to total business lending by the entire German banking system over the same period.” (Bulletin October 1971, p. 784.) In February and March 1971, the Bundesbank undertook a series of forward German marks sales through the Federal Reserve Bank of New York in an effort to offset the attractive interest-rate differential on marks by forcing the mark to a substantial forward discount. The sales failed to stop the dollar inflow, and in mid-March 1971, after \$537 million equivalent in forward mark sales, the Bundesbank halted these operations (Bulletin October 1971, p.791).

The Bundesbank again tried to fine tune its credit conditions. On 31 March 1971, the Bundesbank cut its discount and Lombard rates a full percentage point, but simultaneously reduced banks rediscount quotas by 10 percent (Bulletin October 1971, p. 791). Credit conditions were little changed and speculative pressures on the mark intensified. "Within 3 days, the Federal Bank [Bundesbank] took in more than $\$ 1.3$ billion in holding the spot mark at the ceiling and swapped some $\$ 600$ million of this inflow out in the market for 3 months' delivery.” (Bulletin October 1971, p. 792.) The funds swapped out likely ended up back in the market.

In April the Bundesbank re-instituted 3-month forward sales of German marks. This time, however, the Bundesbank operated in the Frankfurt market, and the Federal Reserve undertook similar forward mark sales for the System's account in the New York market. At this 
time, Eurodollar interest rates began to increase, while German rates also began to ease. The spot mark rate moved off of its ceiling. The System continued concerted forward interventions nearly every day through April 1971, with the Bundesbank selling a total \$1.5 billion equivalent marks and the System selling \$75.7 million equivalent marks (Bulletin October 1971, p. 792). The System covered its operations with existing mark balances and with a $\$ 60$ million swap drawing on the Bundesbank (Bulletin October 1971, p. 792). The Bundesbank ceased these operations on 28 April 1971 (Solomon 1982, 179). Although the operations “calmed" the market and may have brought the spot rate off of the ceiling, strong pressure on the mark quickly resumed. In part, reports of an EEC meeting on 16 April 1971 fanned speculative embers. At this meeting, German Minister Schiller proposed that the European currencies float or revalue together against the dollar, and Minister d'Estaing favored a dollar devaluation (Solomon, 1982, p. 179). During the first four months of 1971 , Germany acquired $\$ 3.0$ billion and at the end of April, had outstanding forward commitments of $\$ 2.7$ billion (Bulletin October 1971, p. 792).

In early May, leading German economic research institutes recommended floating or revaluing the mark, and many German officials gave their suggestion a sympathetic ear (Coombs 1976, p. 213). Speculative flows into Germany then intensified. "The German central bank was forced to buy dollars in mounting volume: more than $\$ 1$ billion on May 3 and 4 and a further \$1 billion in the first 40 minutes of trading on May 5, at which point it withdrew from the market.” (Bulletin September 1971, p. 784.) The Bundesbank stopped intervening. Foreign exchange trading in Frankfurt effectively ended for the next week. Austria, Belgium, the Netherlands, and Switzerland also ceased official operations. The mark began to appreciate in other markets. On 9 May 1971, Germany indicated that it would no longer defend the parity limits although formally Germany kept the parity in place. Germany would now focus policy on keeping inflation low. The mark continued to appreciate until early June.

In June, the mark started to turn around, and the Bundesbank began a series of spot dollar sales. These helped German monetary authorities to tighten monetary policy. "By mid-June the authorities had sold $\$ 1.7$ billion, considerably more than they had taken in under maturing forward contracts from the operations in February and March...” (Bulletin October 1971, p. 793). With the exchange rate less of a constraint on domestic policy, the Bundesbank substantially increased reserve requirements on banks' domestic and foreign liabilities. Interest rates in Germany rose. "Overall, from June 3 through the end of July, the Federal Bank [Bundesbank] sold $\$ 4.8$ billion in the spot market while it took in a total of $\$ 2.7$ billion through maturing forward contracts.” (Bulletin September 1971, 793)

This respite in foreign exchange market proved short-lived, and the Bundesbank stopped selling dollars. By early August 1971, the spot mark reached a level 7.6 percent above its previous parity ceiling.

\section{The Unraveling: 1971 - 1973}

Global monetary authorities viewed the 15 August 1971 closing of the gold window as confirmation that the dollar was overvalued. European exchange markets remained closed for a week, and when they reopened, European governments did not defend their par values. With respect to a future international monetary system, leaders wanted a return to fixed exchange rates, although in a system based on a 'neutral reserve instrument' rather than on the dollar. In addition, world monetary authorities wanted a system in which all parties must participate in any exchange-rate adjustment. They thought that the world was in danger of creeping protectionism 
and recession, in large part because of the administration's import surcharge, which they viewed as a major impediment to realignment (FOMC Minutes, 21 September 1971, p. 5).

Uncertainty pervaded exchange markets during the months leading up to the Smithsonian Agreement of the Group of Ten countries on 18 December 1971. At the Smithsonian, participants agreed to an 8.57 percent hike in the official gold price from \$35 per ounce to \$38 per ounce. The Swiss franc, the Italian lira, and the Swedish krona were also devalued slightly against gold, while the German mark, Japanese yen, Dutch guilder, and Belgian franc were revalued somewhat. The British pound and the French franc remained at their previous parities, and the Canadian dollar continued to float. In addition, the Smithsonian Agreement specified wider margins for currencies around their new central parities. Any currency could move 21/4 percent on either side of its central parity relative to its intervention currency-typically U.S. dollars. This implied that currencies could diverge by as much as $4 \frac{1}{2} 2$ percent against most other currencies.

Funds did not immediately return to the United States; other countries continued to accumulate reserves through the middle of 1972 (IMF, 1972, p. 2). Uncertainty pervaded the market well into 1972 because local governments still had to approve the Smithsonian agreement, and doubts about trade restraints and overall monetary reform persisted. The prospects of another dollar devaluation also lingered. Central banks intervened, but speculation drove many European currencies near the tops of their new parity ranges (Coombs 1976, p. 233). Germany and Japan also imposed further controls on financial flows. On 3 March 1972, French Finance Minister Giscard d' Estaing implied that European authorities would neither accumulate dollars nor allow their currencies to float, but would instead impose restraints of financial flows (Bulletin September 1972, p. 774).

The Federal Reserve System was unable to repay swap obligations during the first quarter of 1972 because foreign exchange rates had generally climbed above their parity levels. The System instead rolled over outstanding swaps. As of March 1972, the Fed had outstanding commitments of nearly \$2.9 billion equivalent (Bulletin, March 1972 pp. 228 - 256). Between mid May and early June, the System undertook a series of small Swiss franc purchases in New York and through the BIS. The System used these francs together with direct dollar purchases from the Swiss National Bank to pay down its swap lines with the latter and with the Bank for International Settlements. The System also bought Belgian francs from the Belgian National Bank and paid down a portion of that line and an outstanding BIS obligation.

Over this period, speculative pressure largely focused on the British pound as Britain's current-account position deteriorated and its labor unrest worsened. Between, 16 June 1972 and 23 June 1972, Britain allowed the pound to float relative to the dollar. Over these six days, however, Britain spent $\$ 2.6$ billion in non-dollar reserves to keep the pound within a 21/4 percent band relative to the Continental European currencies (Bulletin, September 1972, p. 757). The European Community (EC) had instituted the "snake in the tunnel” in March 1972, whereby EC countries agreed to keep their currencies within a 21/4 percent band, while also maintaining a 41/2 percent band vis à vis the dollar. The EC countries also agreed that they would undertake all intervention to maintain the EC bands in European currencies, while still intervening in dollars to defend the Smithsonian parities. Britain intervened, selling European currencies-mostly German marks - that had appreciated 21/4 percent above the pound, while Britain's EC partners bought pounds with their currencies. This slowed the pound's depreciation and simultaneously pulled the stronger European currencies away from the upper limit of their Smithsonian parity 
bands. The mechanism, however, seemed to attract heavy speculation out of dollars and out of British pounds. "In this straining pattern of rates, the markets may have sensed a two-way speculative opportunity to go short of sterling and long of continental currencies in the hope of profiting on both.” (Bulletin, September 1972, p. 758) On 23 June 1972, Britain suspended its participation in both the Smithsonian and EC agreements and let the pound float.

Following the British float, European monetary authorities closed their currencies markets and called a meeting of EC finance ministers in Luxembourg. Denmark withdrew from the EC joint float, and Italy received permission to intervene temporarily in dollars. "By Friday, July 14, [1972] the sterling crisis had generated not only the...flight of \$2.6 billion of funds from sterling into other Common Market currencies but also additional flows totaling over $\$ 6$ billion from dollars into various European currencies and the yen.” (Bulletin, September 1972, p. 758)

U.S. monetary authorities had suspended their intervention operations following the 15 August 1971 closing of the gold window. This action seemed to fuel expectations that the Smithsonian parities would not hold. On 19 July 1972, U.S. monetary authorities offered German marks through a series of sizable transactions (Bulletin, September 1972, p. 758). The initiative came from the Federal Reserve; Treasury officials remained reluctant to intervene (Coombs 1978, p. 226). The System sold \$10.7 million equivalent marks. The Treasury announced: "The action reflects the willingness of the United States to intervene in the exchange markets on occasion when it feels it is desirable to help deal with speculative forces. The action indicates absolutely no change in our basic policy approach toward monetary reform and the necessary efforts on all fronts to achieve a sustainable equilibrium in our balance of payments." (Bulletin, September 1972, p. 759) On August 10, the System began a series of heavy Belgian franc sales (\$9.4 million equivalent), which brought the franc down off of its parity ceiling Between July and September, the Desk intervened on nine days selling \$31.5 million in foreign currencies. (Bulletin, September 1972, p. 759) Fears that the Smithsonian parities would not hold then receded for awhile.

During this period, the System reduced its outstanding swap debt by nearly $\$ 1.9$ billion equivalent bringing the outstanding total to $\$ 1.8$ billion equivalent. Most of this was a repayment of the British swap line, which the System accomplished through regular market purchases of sterling, through direct sterling acquisitions from the Bank of England, and from purchases of sterling from the U.S. Treasury, which previously drew it from the IMF (Bulletin, September 1972, p. 759). The System also repaid a \$300 million swap debt with the Swiss National Bank, through purchases of francs both from the Swiss National Bank and the market. The Treasury, likewise, redeemed two mark-denominated notes and renewed other foreigncurrency denominated securities. As of 8 September 1972, the Treasury had \$2.0 billion equivalent in outstanding foreign-currency securities. In 1972 and in 1973, the Treasury did not participate in U.S. interventions to support the dollar, because it needed foreign exchange to service outstanding foreign currency debts.

In late 1972, the dollar strengthened as the U.S. inflation rate temporarily cooled while inflation rates elsewhere rose. In October, the Swiss used the opportunity to sell dollars and drain liquidity from Swiss markets. "In general, European monetary authorities saw the improvement of the dollar as providing them with an opportunity to move more forcefully in the fight against increasingly virulent inflation. Thus, over the course of the fall monetary policy in Europe was tightened progressively, both through changes in reserve requirements and through increases in discount rates.” (Bulletin, March 1973, p. 143.) Despite a rise in U.S. interest rates, 
Europeans became concerned that the United States would not go far enough to prevent inflationary pressures in this country.

By early 1973, confidence in the Smithsonian agreement was again rapidly waning. Markets were concerned about the prospects for creeping protectionism and the lack of progress on reform of the international monetary system. On 20 January 1973, Italy instituted a two-tier exchange rate system. Italian banks then began buying Swiss francs to cover outstanding currency obligations. This bid up the Swiss franc, which was already close to its upper parity limit, and it forced the Swiss National Bank to acquire \$270 million. Fearing a continued inflow that would undermine its anti-inflation policy, the Swiss allowed the franc to float. The currency quickly moved well above its Smithsonian ceiling and speculation shifted to the German mark. Germany accumulated reserves as the mark appreciated.

On 24 January 1973, the System, in concert with Germany, sold \$30 million marks in the New York market, and over the next two days the Desk made modest mark sales, which apparently moved the mark "slightly lower.” (Bulletin, March 1973, p. 144) System mark sales in all of January amounted to $\$ 98.7$ million equivalent. Pressure on the mark, however, intensified following the release of German trade data and began to affect the Dutch guilder as well. The System began selling guilder and marks in New York.

Between January 24 and February 2, 1973, all interventions in marks and guilder were for the System's own account. The System sold on net $\$ 173.3$ million equivalent marks in February 1973. When the System's holdings of marks ran out, the Treasury began mark sales from its account. $^{81}$ The Treasury sold $\$ 46.6$ million equivalent marks in February. In addition the System sold \$20.4 million worth of guilder, exhausting its holdings of guilder. Interventions continued, but the market came to believe that the Smithsonian parities would not last. The Bundesbank acquired $\$ 6.0$ billion during the first week of February (Bulletin, March 1973, pp. 144-45).

On 12 February 1973, with European and Japanese markets closed, the United States devalued the dollar 10 percent. This second dollar devaluation brought the official gold price to $\$ 42$ per ounce. When the markets reopened, Japan allowed the yen to float temporarily. The dollar temporarily strengthened, allowing the System to purchase foreign exchange to cover maturing swap commitments. The transactions, however, were ill-timed from the perspective of signaling to the market. The flow of funds into European currencies soon continued despite the devaluation of the dollar, and the dollar dropped to its floors against the German mark, French franc, Dutch guilder, and Belgian franc by February 23, 1973. Dollar holders were shaken, and the flow of funds into Europe accelerated. On 1 March 1973, an unprecedented \$3.6 billion moved into European central banks, inducing authorities closed their exchange markets (Coombs 1976, p. 229).

On 10 March 1973, Germany, France, Belgium, the Netherlands, and Denmark agreed to maintain fixed exchange rates among themselves with a band of 21/4 percent around the central parity, and to float jointly against the dollar. Germany also devalued 3 percent. Norway and Sweden subsequently joined the joint float, but the Italian lira, Swiss franc, British sterling, and Japanese yen continued to float independently. The Bretton Woods system ended. 


\section{Outstanding Obligations from Swaps and Bonds}

At the end of August 1971, the System had outstanding swap obligations totaling approximately \$3.0 billion in U.K. pounds, German marks, Swiss francs and Belgian francs (Task Force Paper \#10, p. 21). The Treasury had outstanding obligations totaling nearly \$1.8 billion in German marks and Swiss francs, which with the closing of the gold window, the Treasury could not extinguish with gold sales (Task Force Paper \#10, p. 21). The revaluations clauses that were typical in swap drawings and Roosa bonds did not apply to a move from fixed parities to floating rates, since it was hard to determine if a creditor country appreciated or if a debtor country depreciated. The revaluation clauses only pertained to situations in which the creditor country revalued its currency. In 1972, the position emerged that if all of the G10 currencies appreciated together, that would imply a dollar deprecation (FOMC Minutes, 21 March 1973, p 63). Suppose, however, that one currency appreciated by more or less than the G10 average. Should the revaluation clause apply? The situation was unclear. Without the revaluation clauses or some form of risk sharing, the United States faced a substantial loss on its outstanding obligations.

The System did not experience much difficulty in paying down its German mark and U.K. pound obligations (see above). It had acquired marks through a swap drawing in May 1971 to cover some current forward positions. The Desk acquired marks both from the market and from a central bank to pay off its swap debt by July 1972. Likewise, the System bought sterling in the market and extinguished it debts when the pound came under strong downward pressure in July and August 1972 (FOMC Minutes 18 July 1972, p. 17 - 18).

The System had more difficulty in extinguishing its Belgium and Swiss franc obligations. In part, this resulted because the Belgium franc and Swiss franc were often strong in the market, and National Bank of Belgium and the Swiss National Bank did not want market purchases that would encourage further appreciation. Some of the $\$ 600$ million Belgian debt was repaid in 1971 and 1972, when the System made small periodic franc purchases at the request of the National Bank of Belgium. In December 1973, however, the System halted such purchases, when the Treasury sought to clarify the issue of risk sharing with both of these central banks and, therefore, the terms of debt repayment. The Treasury wanted equal sharing, but the Belgians "interpreted this request as a change in the original agreement and felt no obligation to comply." (Task Force Paper \#10, p. 23).

After delaying, the System reached an agreement with the National Bank of Belgium. "In December 1975, the System and the National Bank of Belgium agreed to adjust the outstanding swap debt to take into account the revaluation of the Belgian franc in 1971, and the two devaluations of the dollar in 1971 and 1973.” (Task Force Paper \#10 1990, p. 23) As a consequence, the System's outstanding swap debt was increased by $\$ 54.1$ million. Near the end of 1975, with the Belgian franc-U.S. dollar exchange rate at a level that made losses associated with the remaining liability small, the System began a series of Belgian franc purchases. By November 1976, the System had liquidated the Belgian franc debt.

In August 1971, the System had $\$ 1.0$ billion in outstanding swap obligations with the Swiss National Bank, the full amount of the line, and \$600 million in outstanding Swiss franc swap obligation to the BIS. Over the next four years, the System made periodic purchases of Swiss francs both in the market and from the Swiss National Bank to retire this debt. In December 1975, the System added \$196 million equivalent francs to its outstanding swap debt 
with the SNB to reflect losses associated with two dollar devaluations. ${ }^{82}$ Shortly, thereafter, the System and Treasury reached a loss sharing agreement with the Swiss National Bank. In February 1976, the System drew \$600 million on the SNB swap line to pay down the BIS Swiss franc line completely. Then in October 1976, the System undertook an unusual transaction to pay down the entire line with the Swiss National Bank. The System negotiated a new "special" swap line with the SNB that embodied the risk sharing agreement and set three-year timetable for repayment. The Swiss National Bank also agreed to sell the System and the U.S. Treasury Swiss francs if necessary. The System paid off the original swap with a drawing on this special swap, and paid off the special line by April 1979. The Treasury also paid off its outstanding Swiss franc obligations in April 1979.

The System and the Treasury took seven and a half years to pay off its pre-August 1971 swap obligations. The estimated losses to the System and to the Treasury on these outstanding debts was \$986 million and \$1.5 million respectively (Task Force Paper \#10 1990, p. 25).

\section{Conclusion}

Triffin's paradox fundamentally threatened the Bretton Woods system. Although efforts to repair this basic flaw - to provide a source of liquidity not based on U.S. balance-of-payments deficits-got underway in the mid-1960s, a high U.S. inflation rate and inevitable cross-rate adjustment problems overtook these efforts. By 1971, Bretton Woods was quickly unraveling. By 1973, it was gone. Floating exchange rates were the predictable consequence of countries' unwillingness to make domestic economic objectives-price stability and full employmentsubservient to the maintenance par values. While U.S. foreign-exchange-market operations may have delayed the disintegration of Bretton Woods, they did not address the system's deep-seated weaknesses, and they arguably prolonged an inevitable breakdown.

The U.S. institutional mechanisms for foreign-exchange-market interventions survived the collapse of Bretton Woods and would adapt to a floating exchange-rate regime. The fundamental reservations about these operations - their uncertain effectiveness, their interaction with monetary policy, and their potential threat to Federal Reserve independence-would also remain. Attitudes about them would evolve along with thoughts on the proper role of monetary policy. 
Figure 1: Real and Nominal Gold Prices

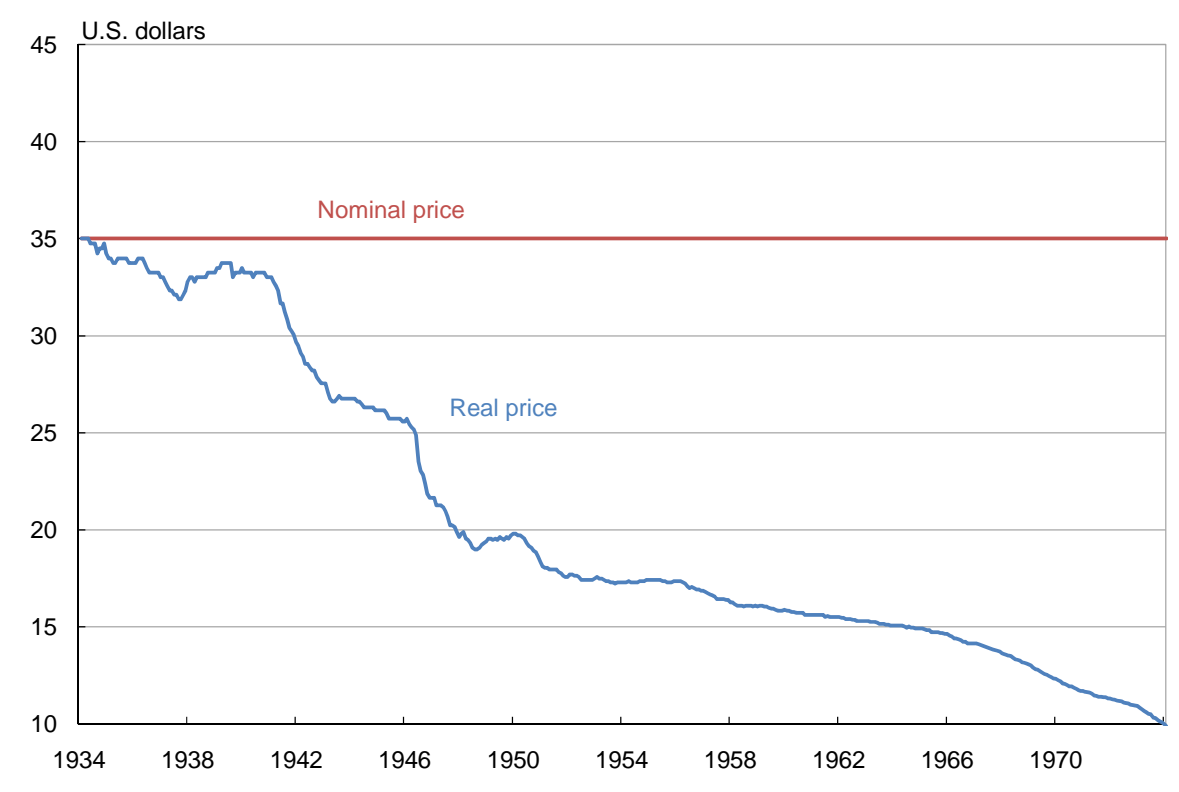

Source: Bureau of Labor Statistics

Figure 2: U.S. Balance of Payments Trends, 1946-1969

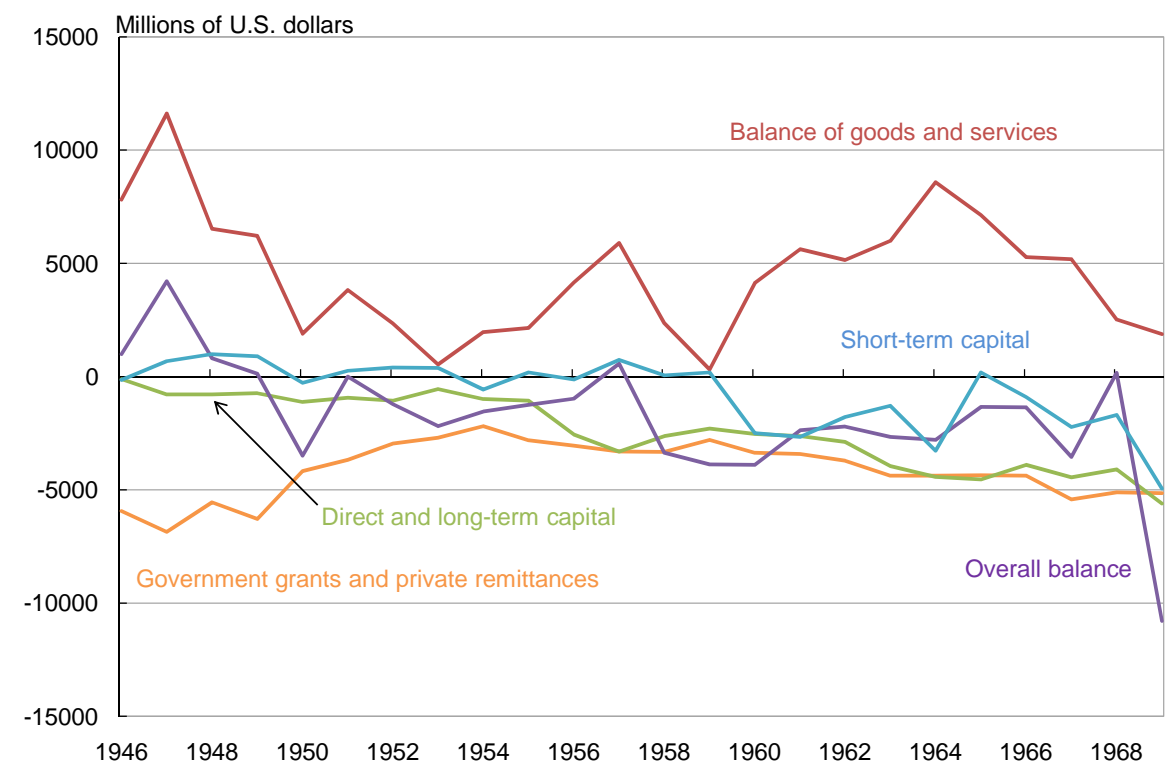

Source: U.S. Department of Commerce 
Figure 3: U.S. Gold Stock and External Liabilities

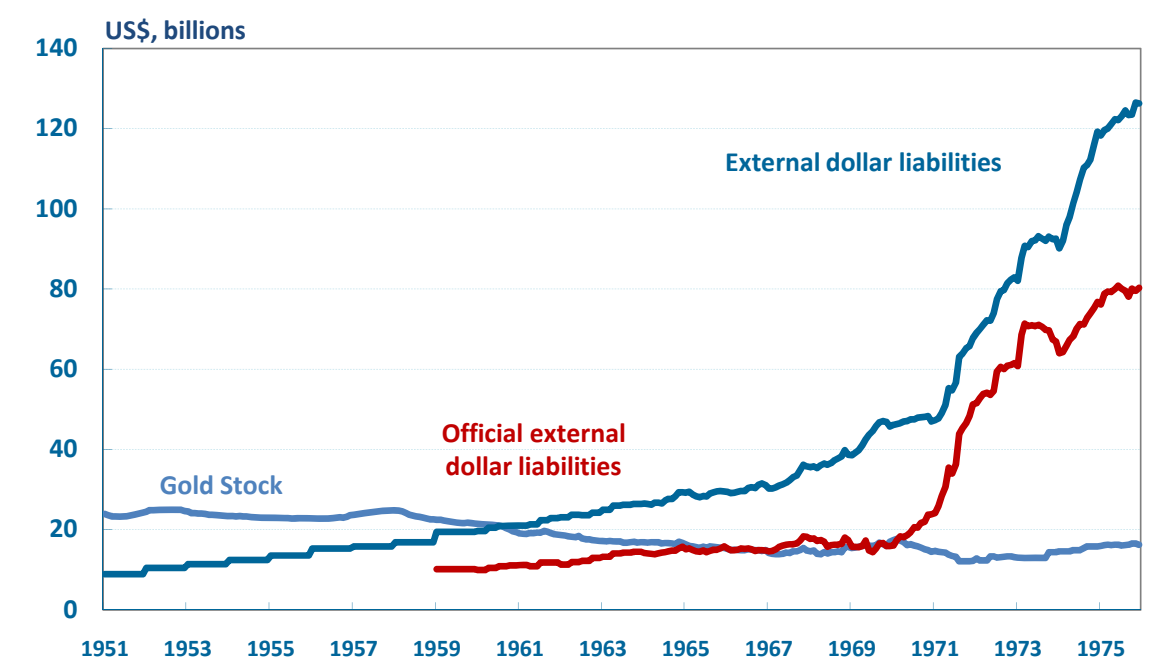

Source: Banking and Monetary Statistics 1941-1970. Washington D.C. Board of Governors of the Federal Reserve System. September 1976 Table 14.1, 15.1

Figure 4: U.S. Gold Stock, 1951-1976

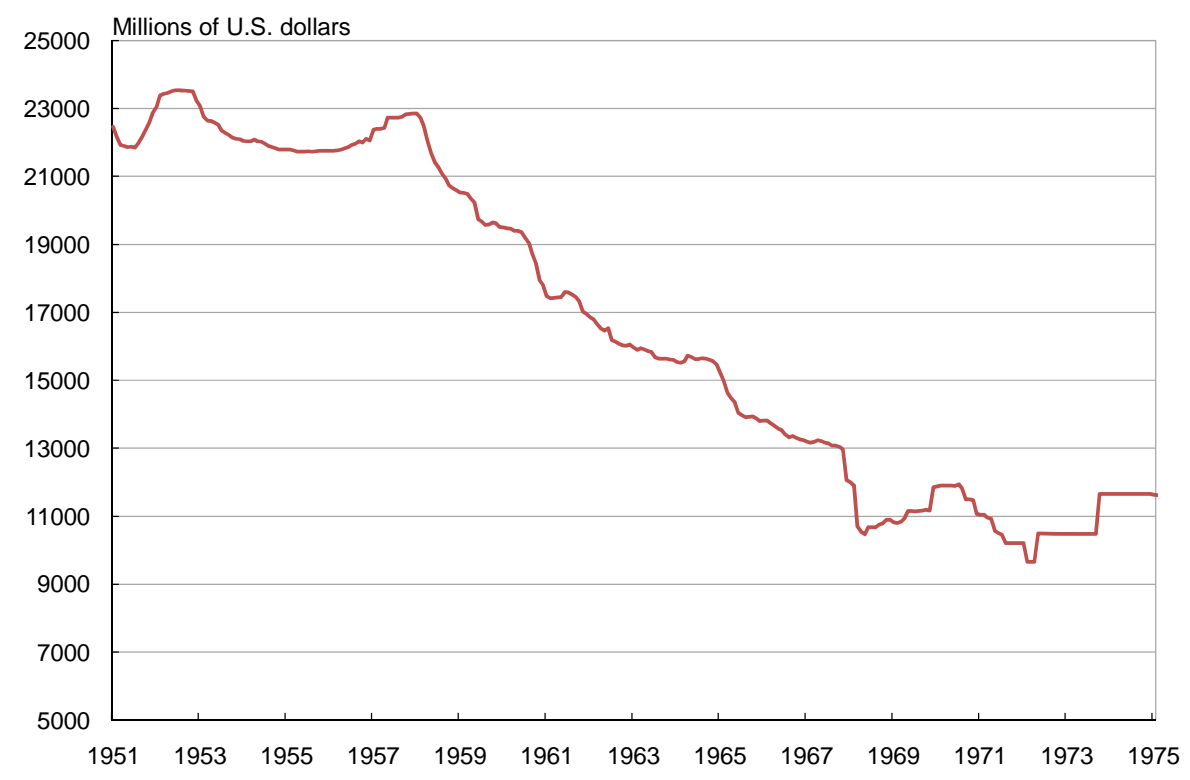

Source: Federal Reserve Bulletin 
Figure 5: Federal Reserve Policy Rates

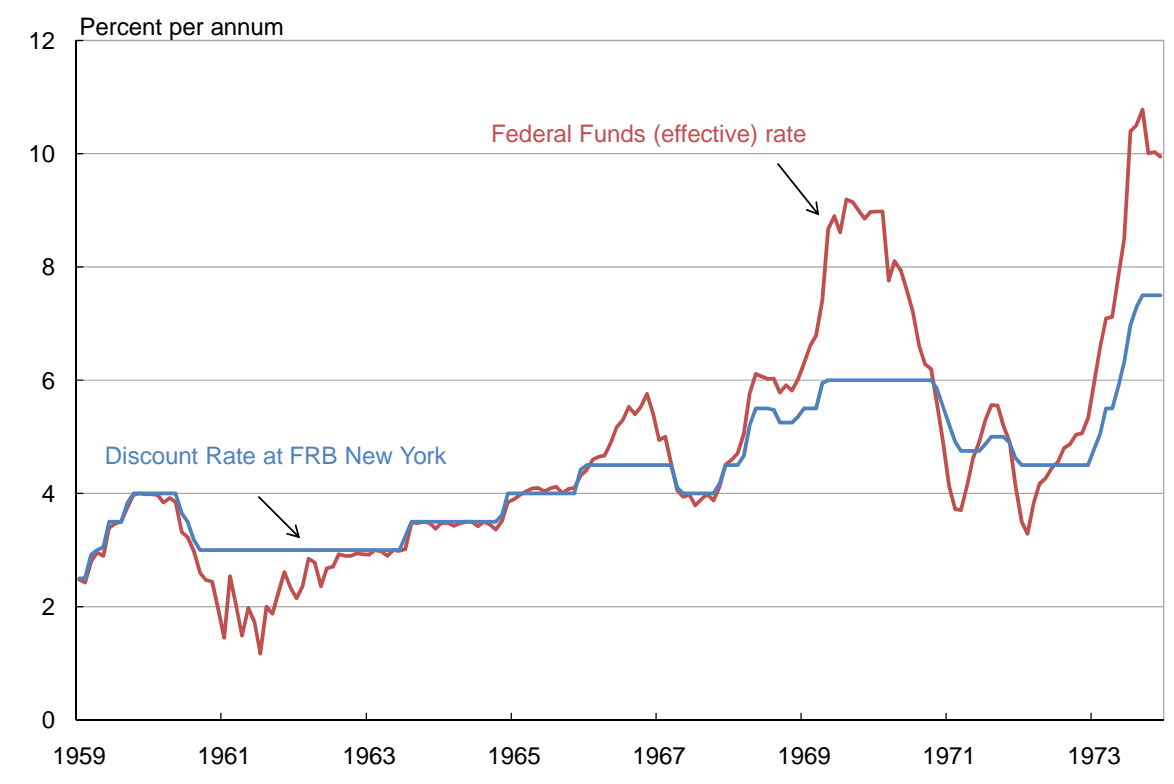

Sources: Federal Reserve Board/Haver Analytics

Figure 6: Ex Post Real Federal Funds Rate

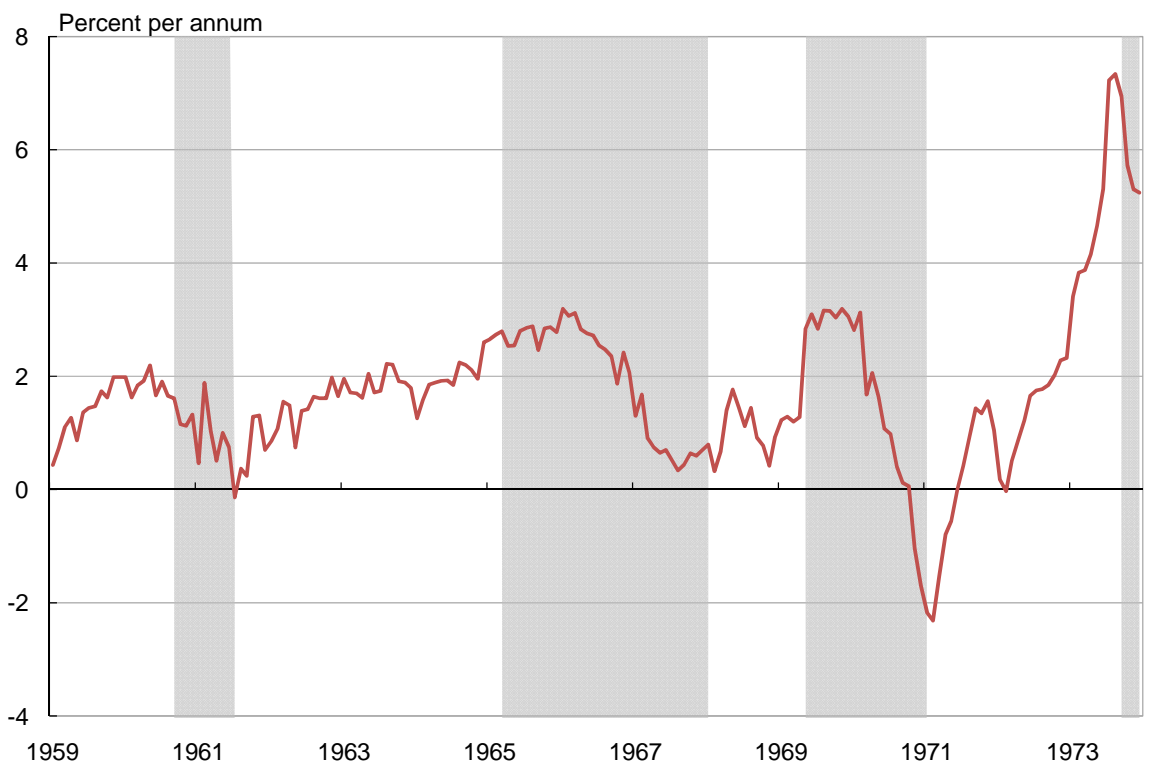

Sources: Federal Reserve Board; Bureau of Labor Statistics 
Figure 7: Federal Reserve Swap Lines $1962-1973$

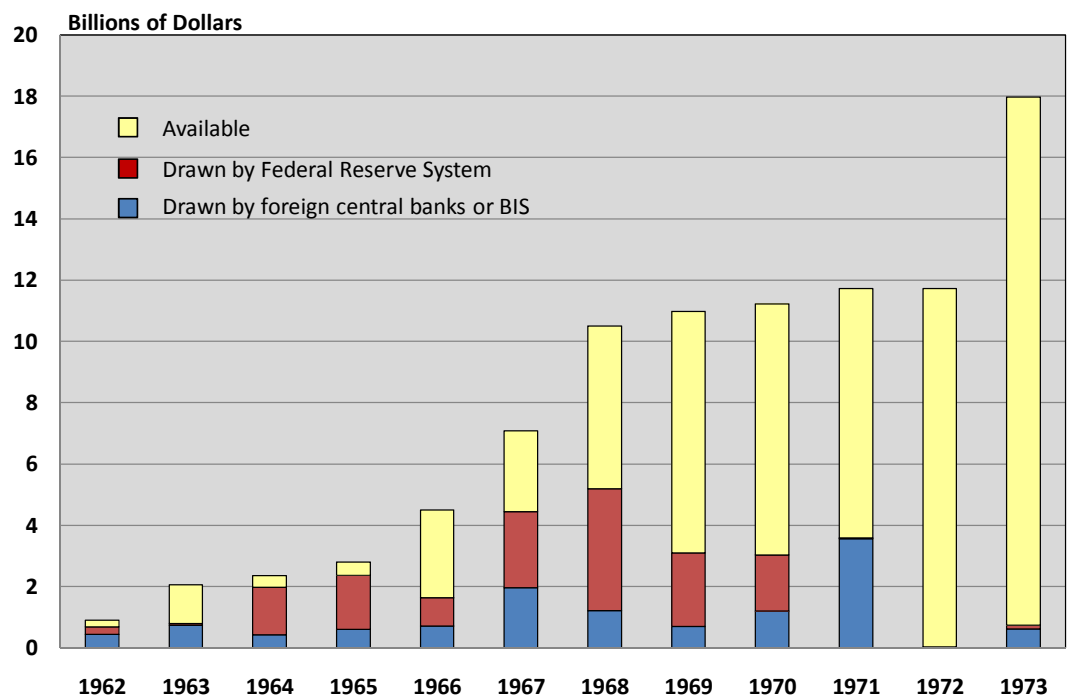

Source: Federal Reserve System

Figure 8: Composition of Swap Drawings 1962 -1971

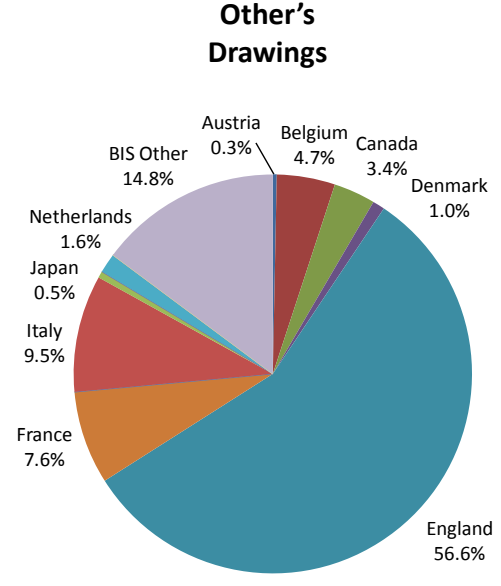

Total: $\$ 15.3$ billion

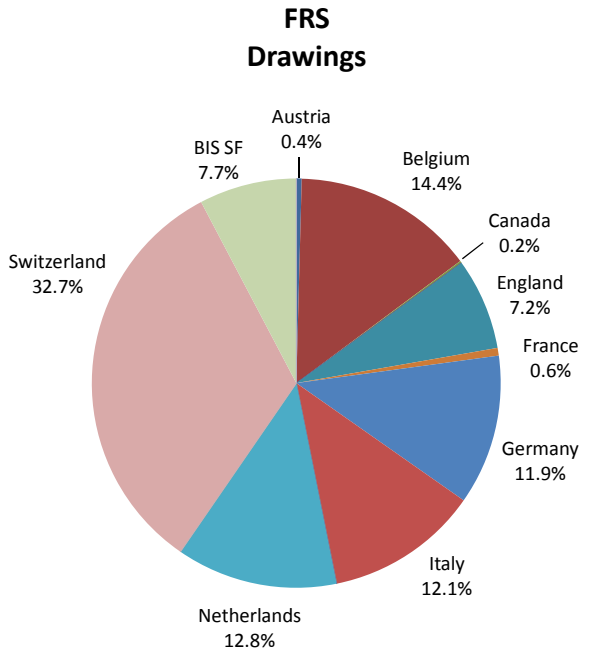

Total: \$11.5 billion

Source: Federal Reserve System 
Figure 9: Federal Reserve Sources and Uses of UK Pounds

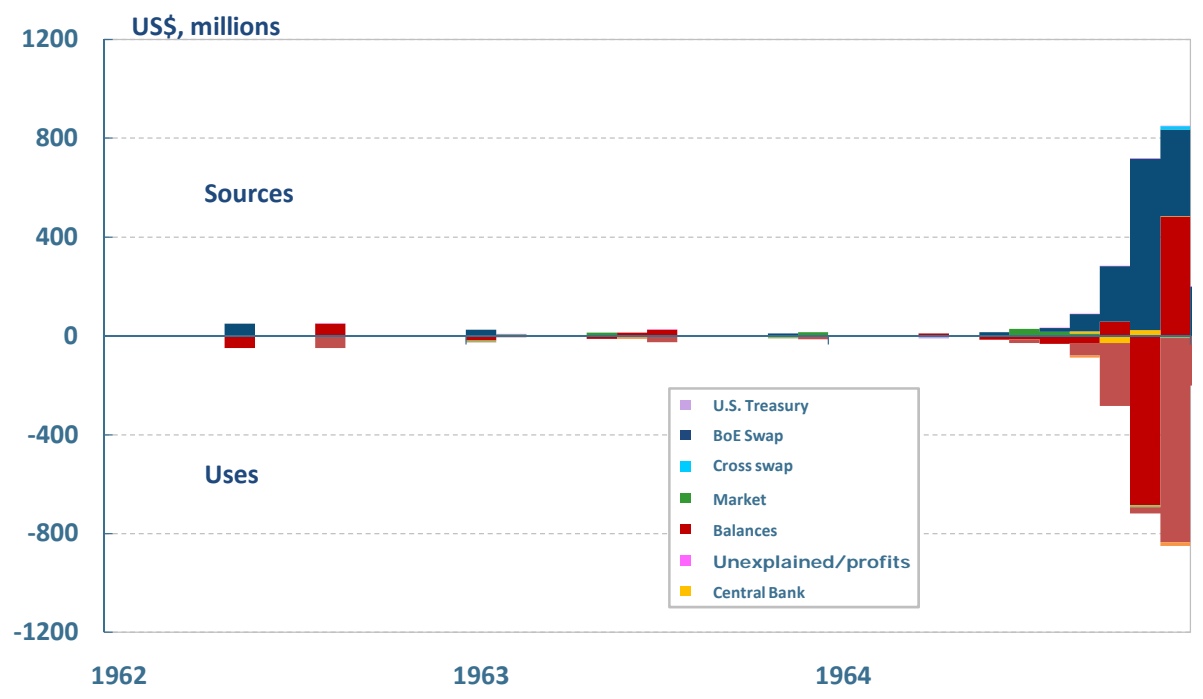

Source: Federal Reserve System

Figure 9: (continued)

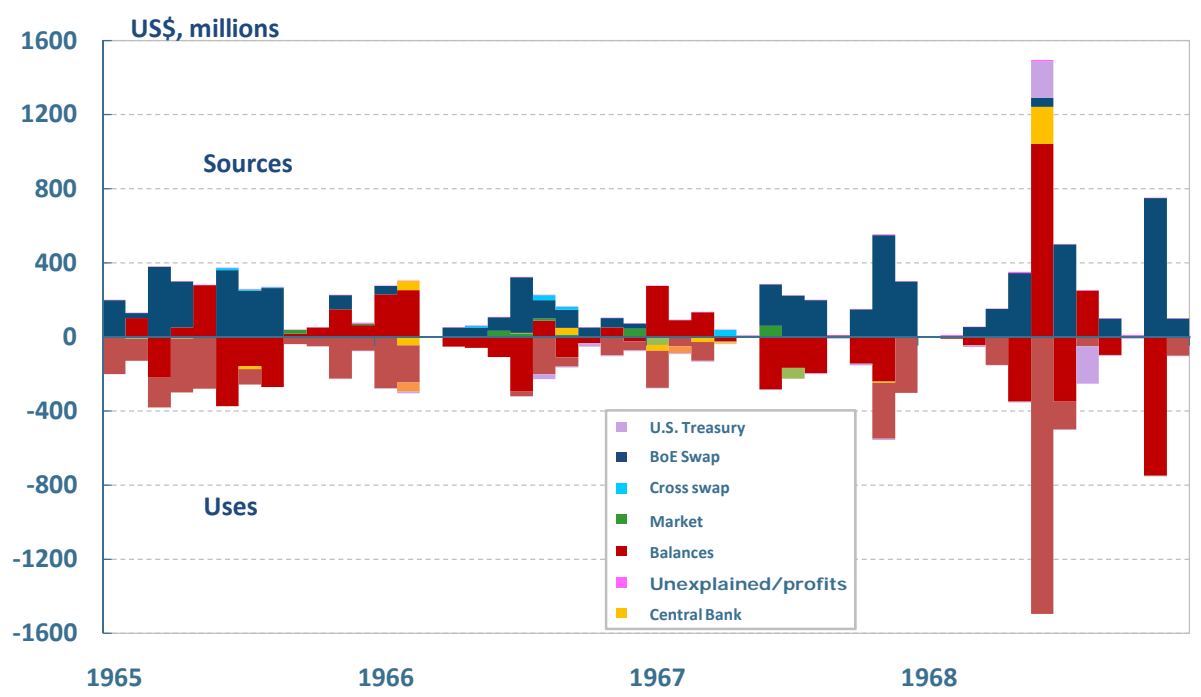

Source: Federal Reserve System 
Figure 9: (continued)

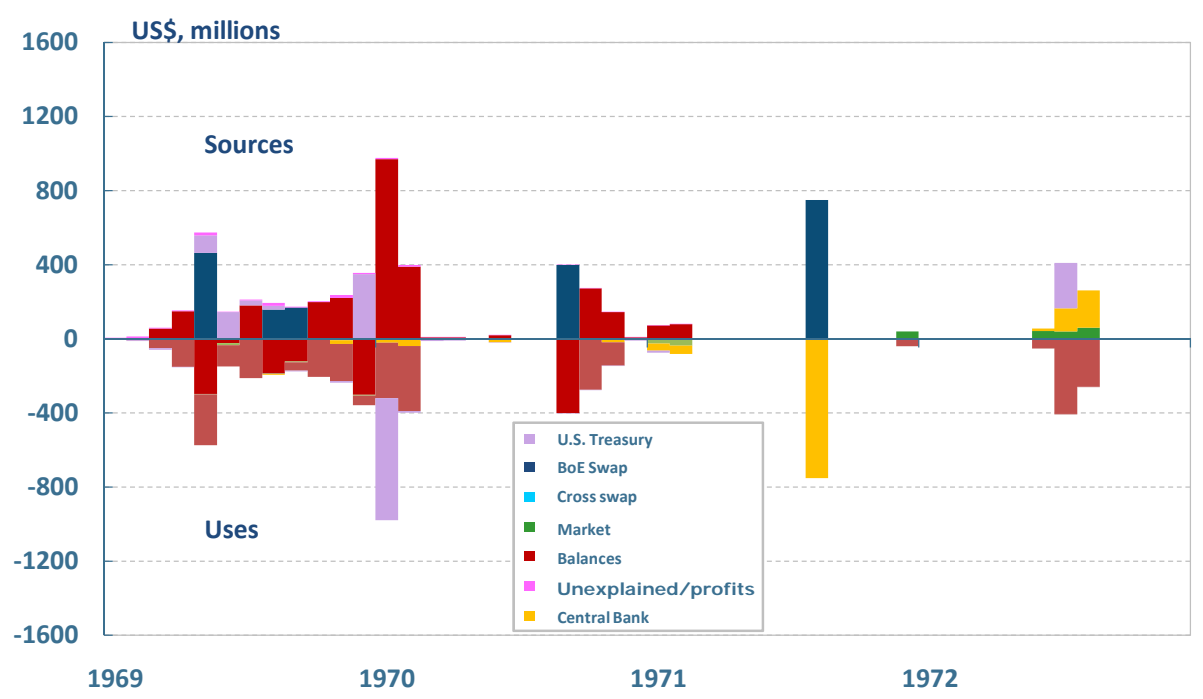

Source: Federal Reserve System

Figure 10: U.S. Treasury Sources and Uses of UK Pounds

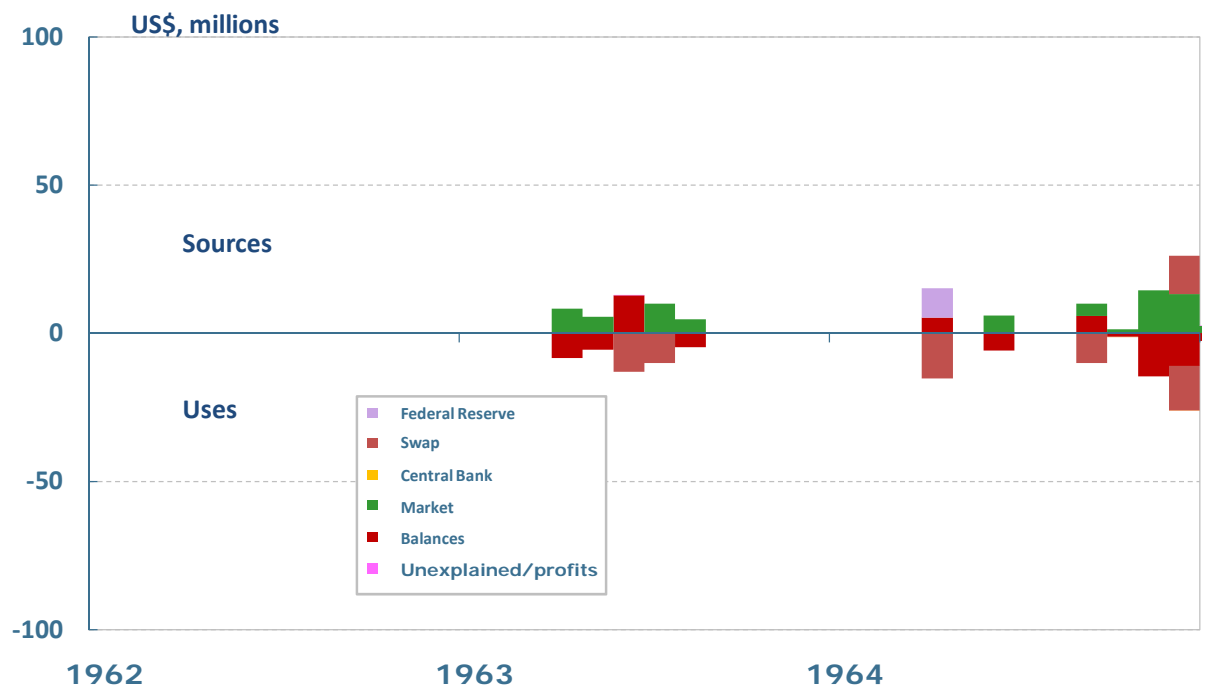

Source: Federal Reserve System 
Figure 10: (continued)

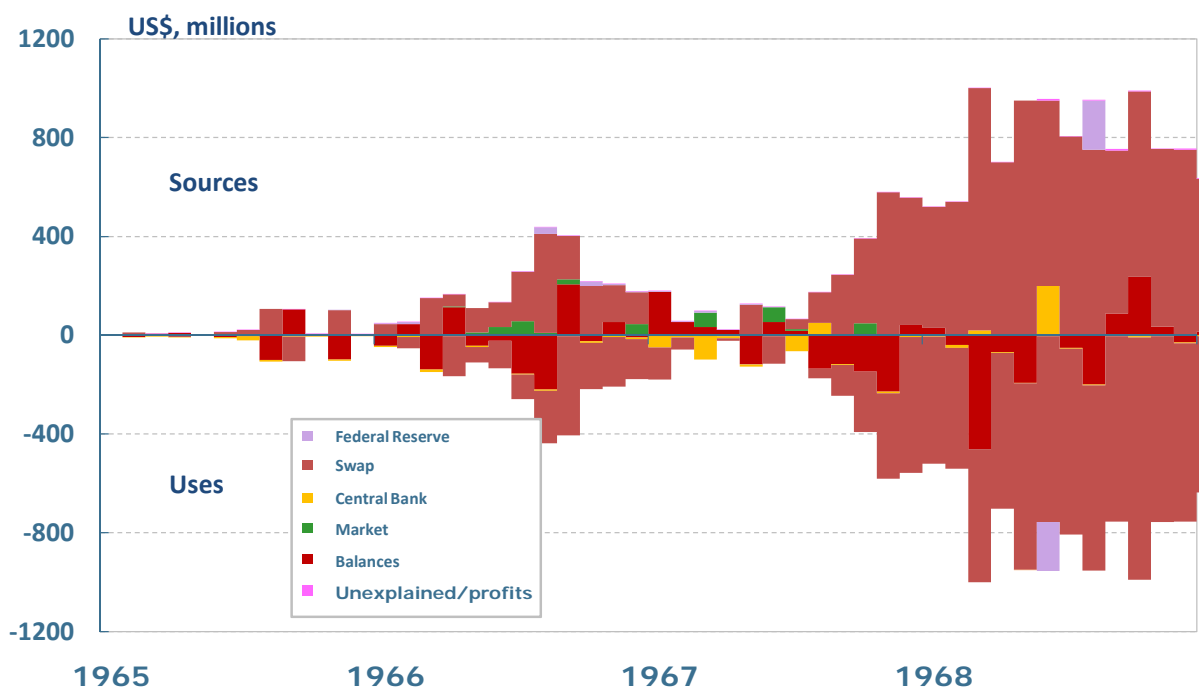

Source: Federal Reserve System

Figure 10: (continued)

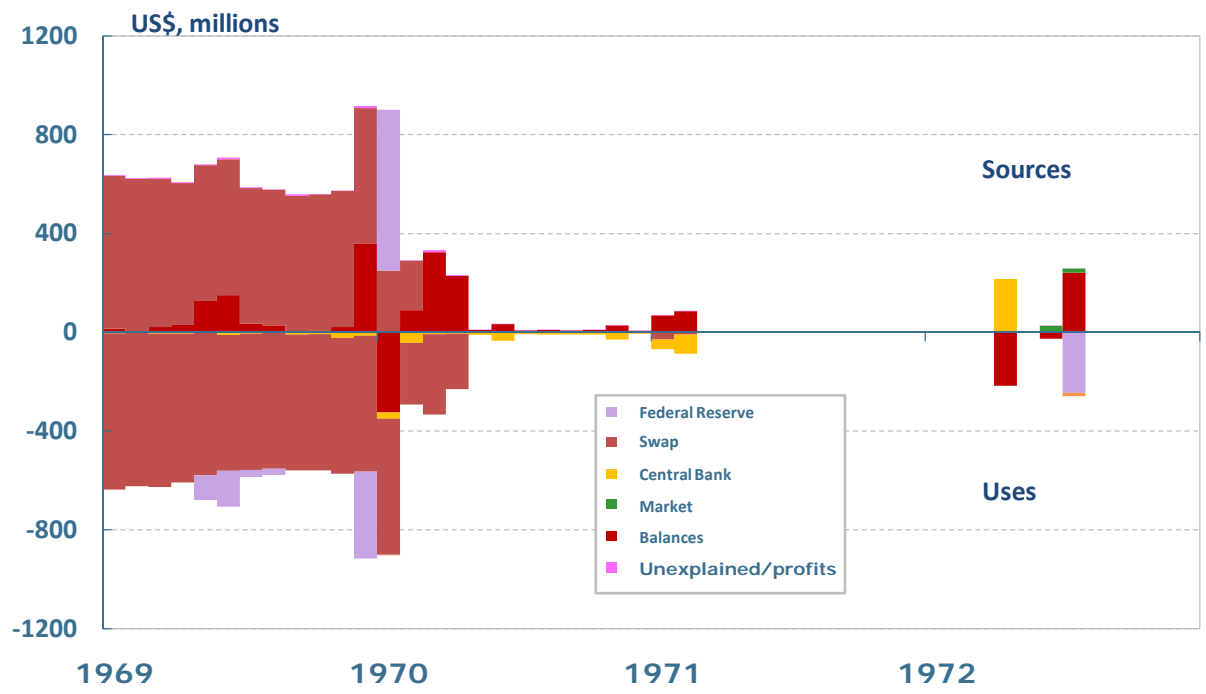

Source: Federal Reserve System 
Figure 11: Federal Reserve Sources and Uses of French Francs

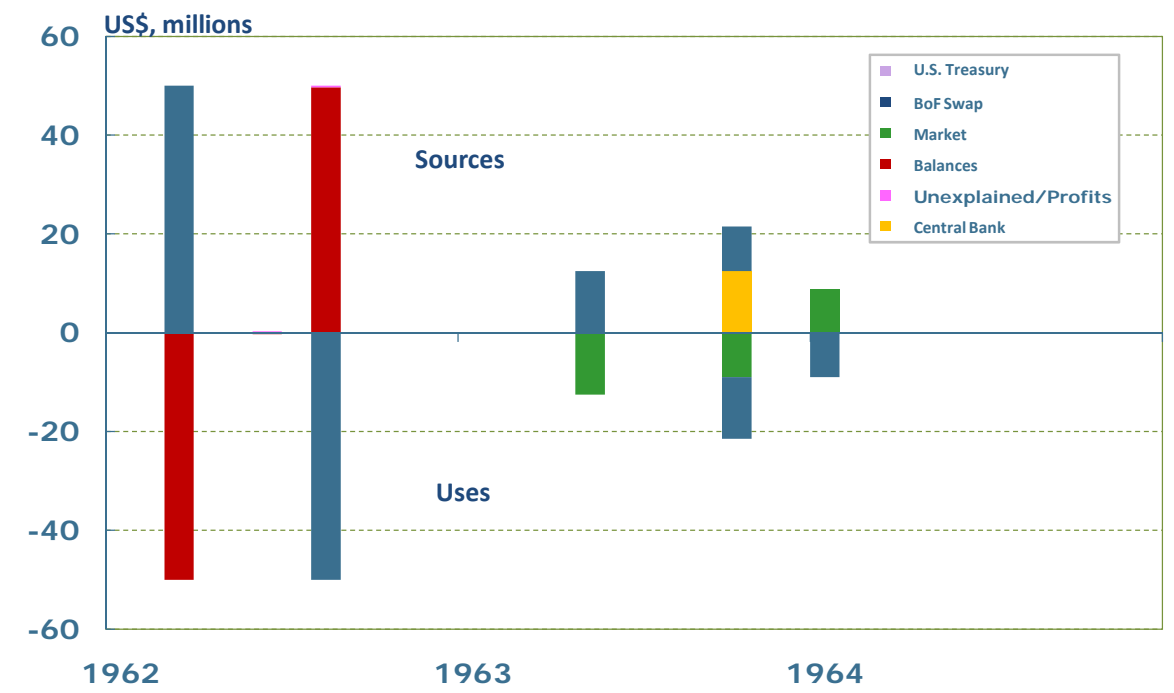

Source: Federal Reserve System

Figure 11: (continued)

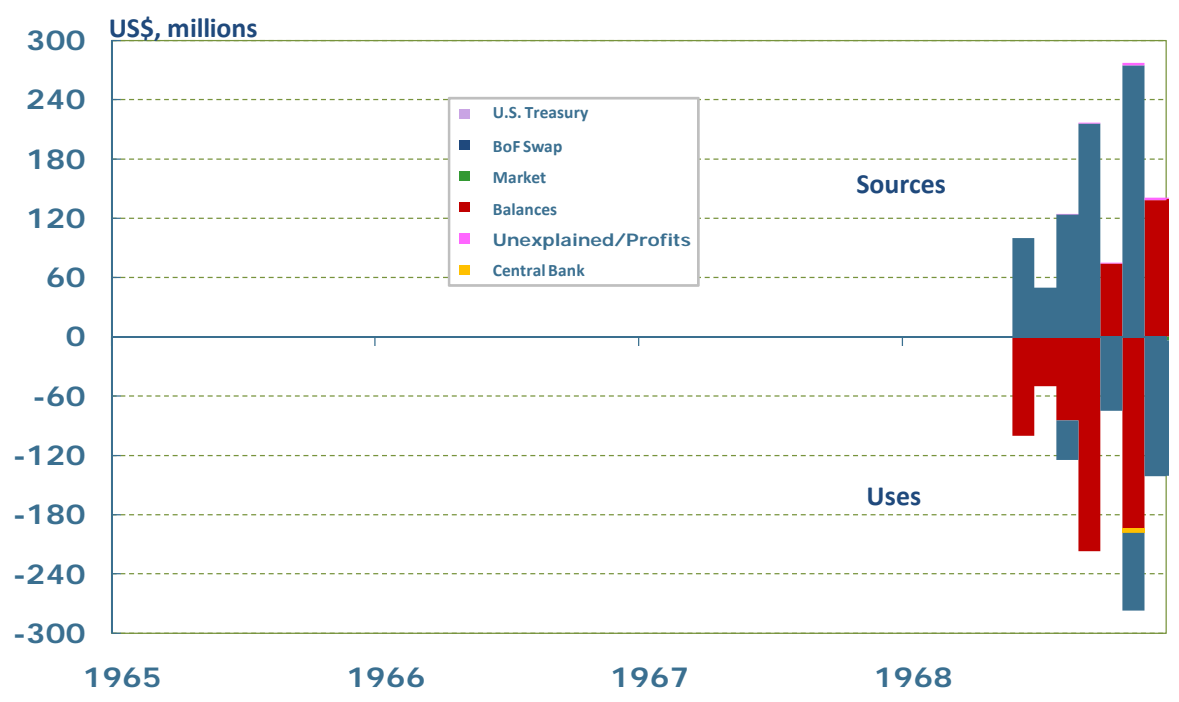

Source: Federal Reserve System 
Figure 11: (continued)

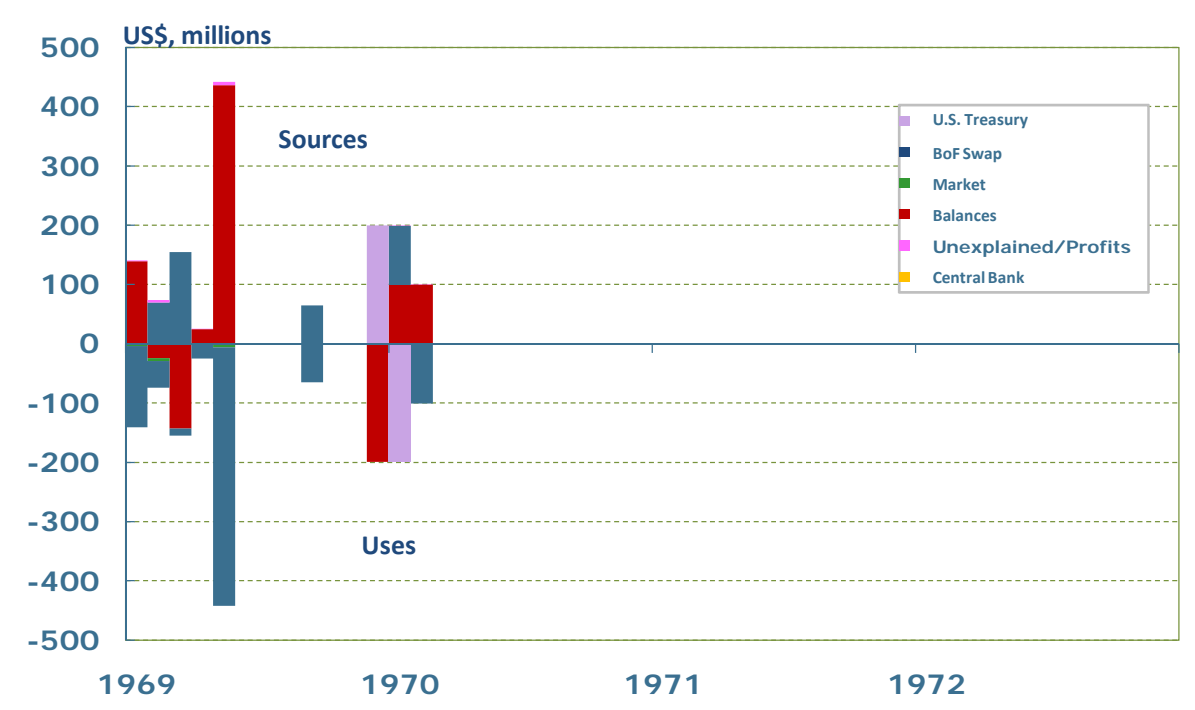

Source: Federal Reserve System

Figure 12: U.S. Treasury Sources and Uses of French Francs

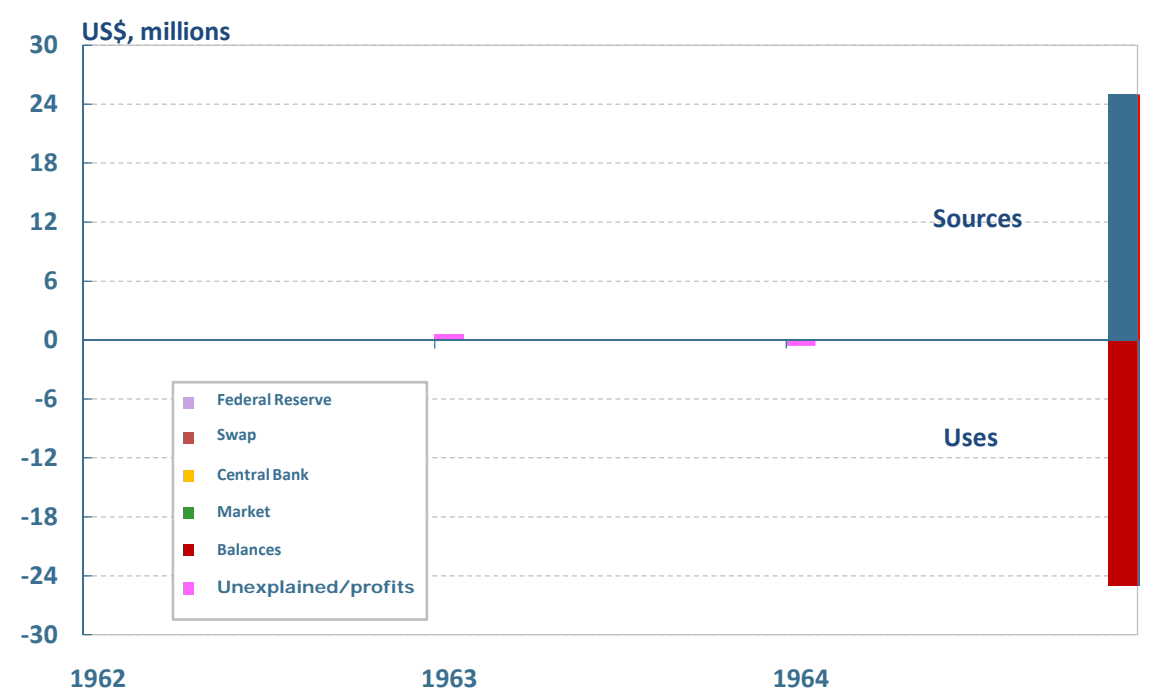

Source: Federal Reserve System 
Figure 12: (continued)

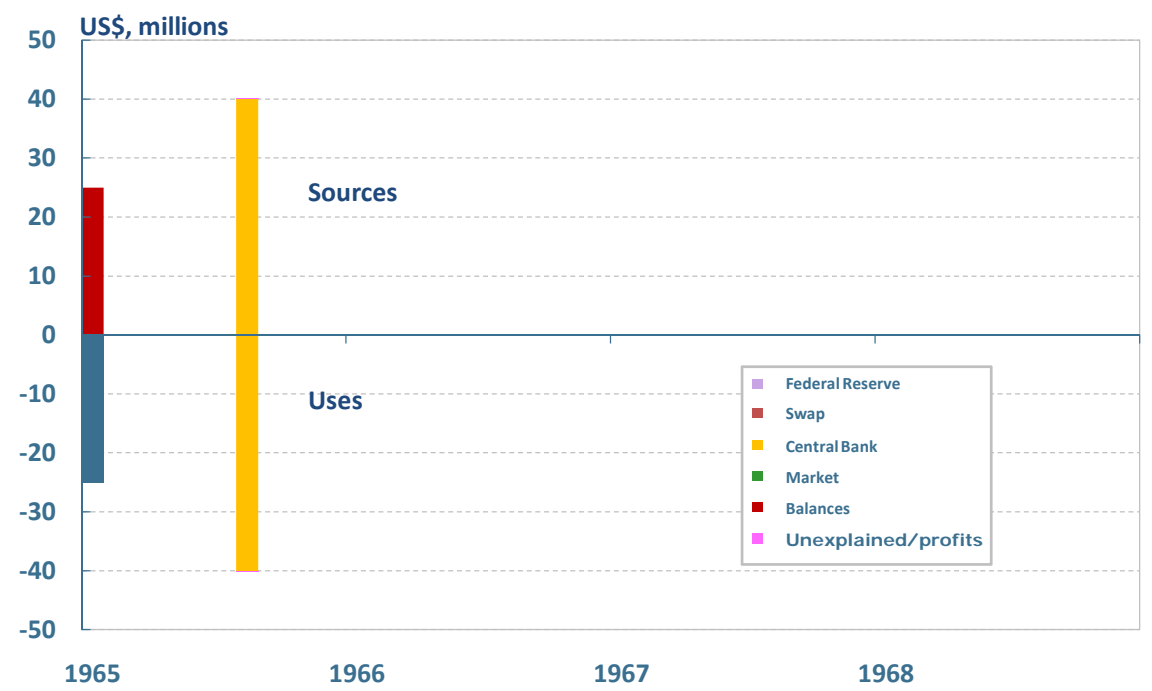

Source: Federal Reserve System

Figure 12: (continued)

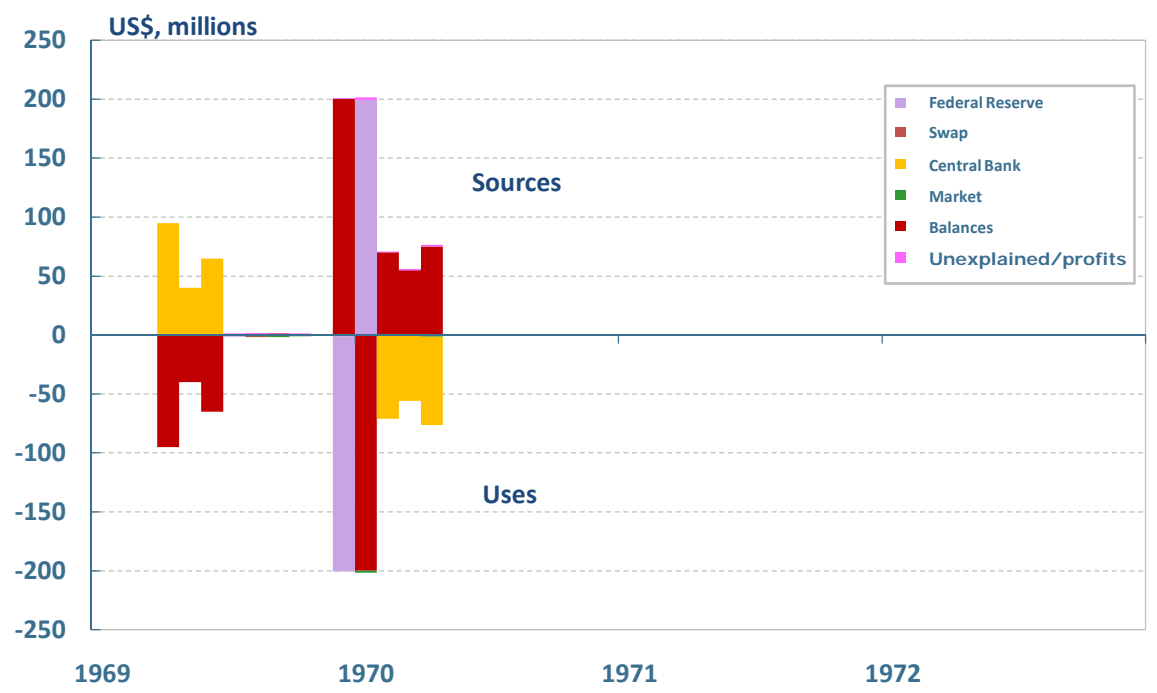

Source: Federal Reserve System 
Figure 13: Federal Reserve Sources and Uses of German Marks

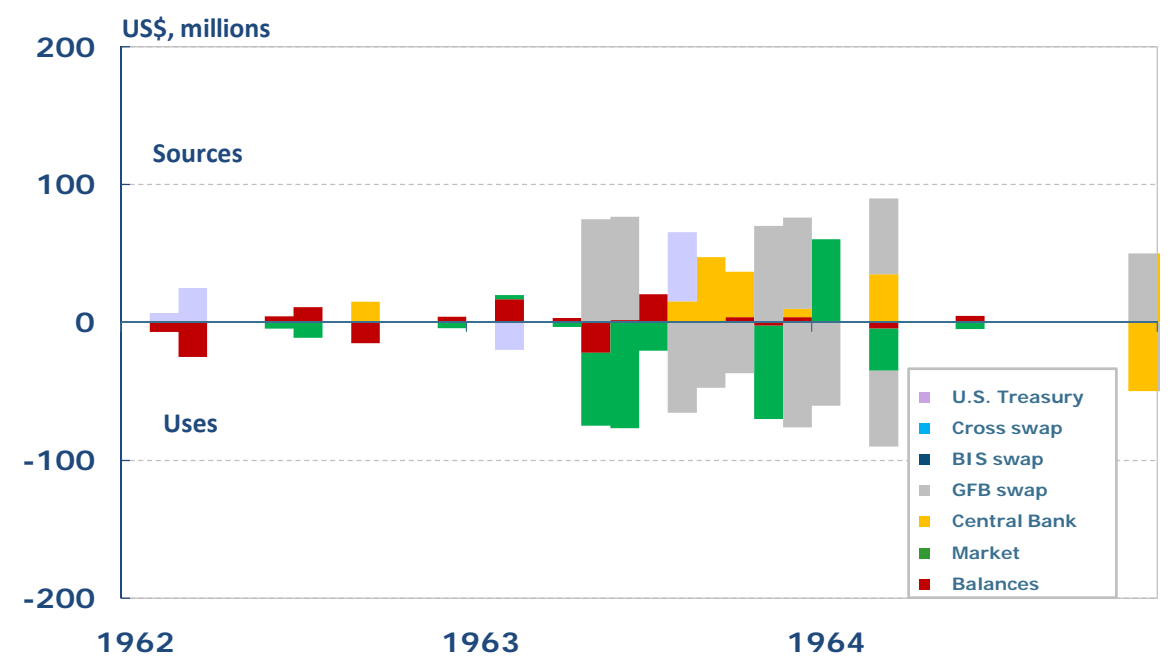

Figure 13: (continued)

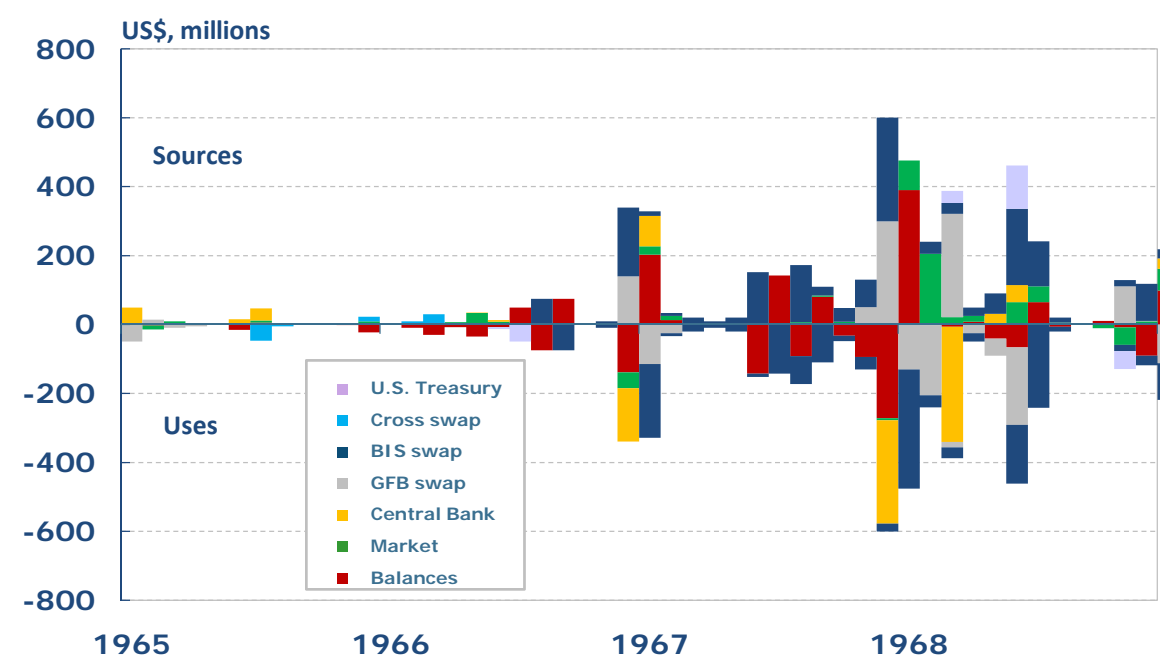


Figure 13: (continued)

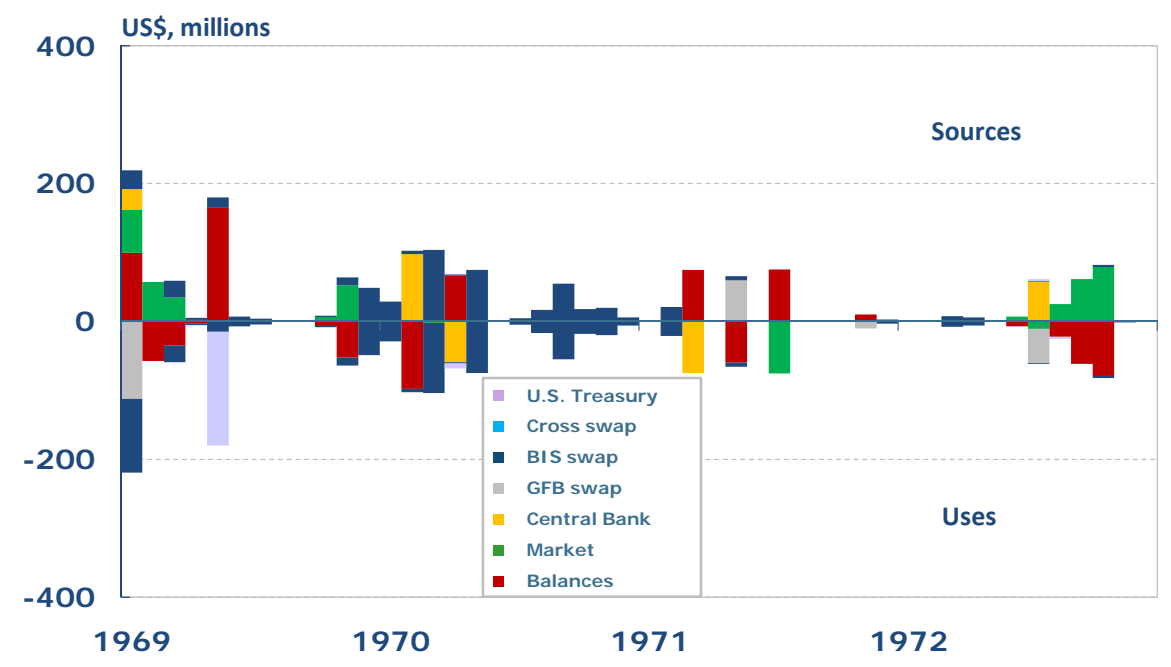

Figure 14: U.S. Treasury Sources and Uses of German Marks

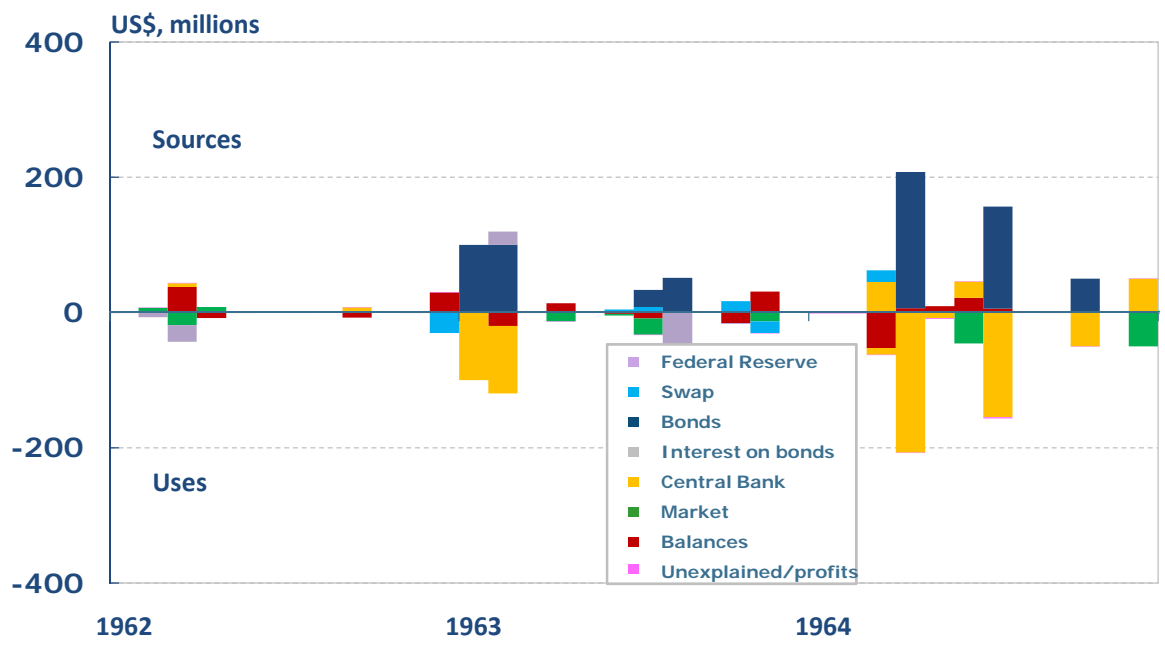


Figure 14: (continued)

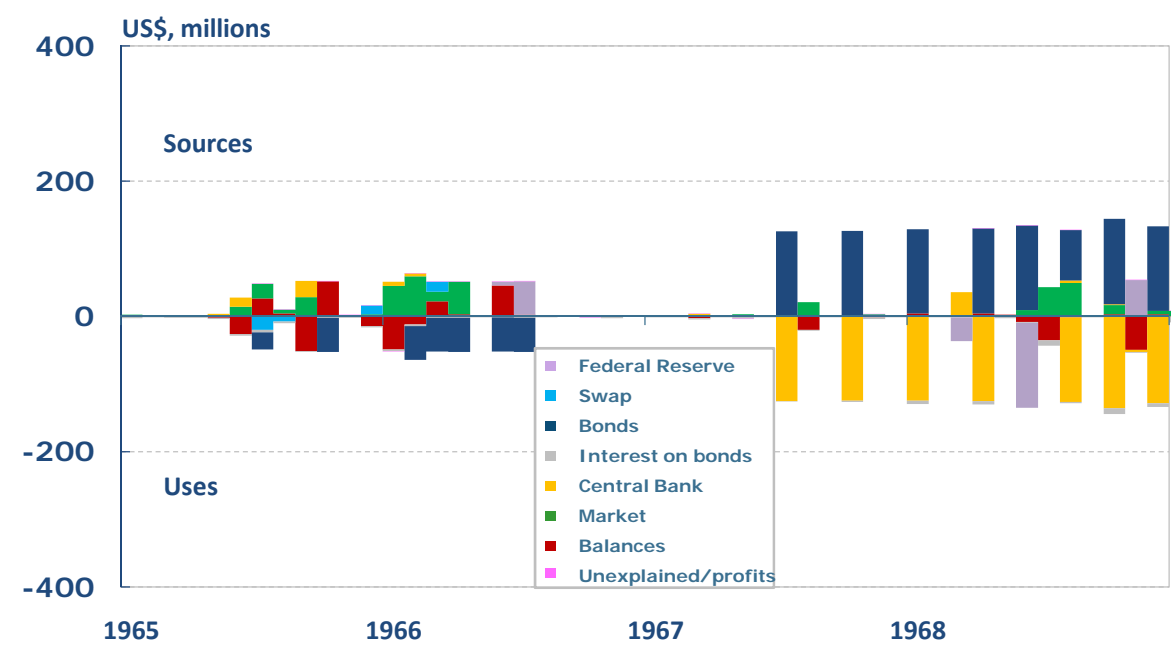

Figure 14: (continued)

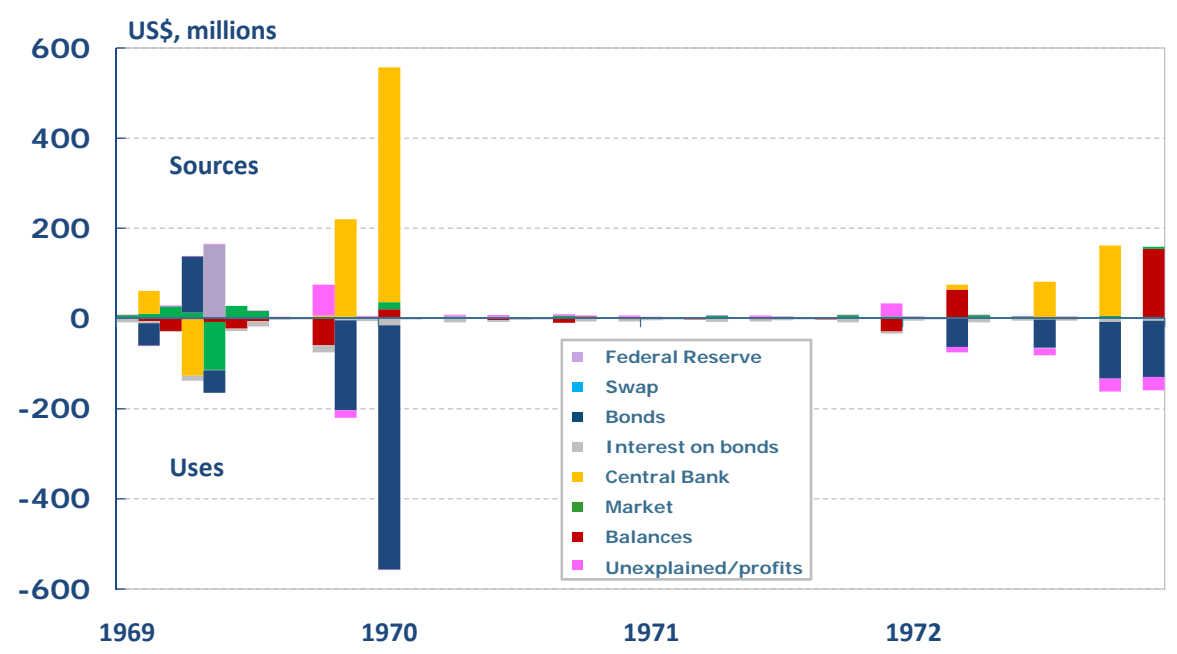




\section{References}

Abreviations use in the text for references:

BIS: Bank for International Settlements

Board: Board of Governors of the Federal Reserve System

Bulletin: Treasury and Federal Reserve Foreign Exchange Operations, or Treasury and Federal Reserve Foreign Exchange Operations: Interim Report.

Desk Report: Federal Reserve Bank of New York, Annual Report on Operations in Foreign Currencies

FOMC Memoranda: Federal Open Market Committee, Memoranda of Discussion.

FOMC Minutes: Federal Open Market Committee, Minutes of the Federal Open Market Committee.

FOMC Transcripts: Federal Open Market Committee. Transcripts of Federal Open Market Committee.

IMF: International Monetary Fund

Task Force: Task Force on System Foreign Currency Operations.

Bank of England 1964. “The London Gold Market,” Quarterly Review, 4(1): 16-21

Board of Governors of the Federal Reserve System. 1966. Federal Reserve Operations in Foreign Exchange, 1962-1966. unpublished memorandum (March 21).

Board of Governors of the Federal Reserve System. (1976) Banking and Monetary Statistics $1941-1970$.

Board of Governors of the Federal Reserve System. (1963) "Financing the U.S. Payments Deficit.” Federal Reserve Bulletin, (April, 1963) pp. 421 - 428.

Board of Governors of the Federal Reserve System. (1968) "Treasury Views Concerning 'Backstopping' of Federal Reserve Swap Arrangements,” staff memorandum to the FOMC. (June 3, 1968).

Bodner, David E. 1970. "Proposed Modification of Procedures to Be Employed in Transactions under Certain Swap Lines.” 3 December 1970.

Bordo, Michael D. (1993) “The Bretton Woods International Monetary System: A Historical Overview.” in M. Bordo and B. Eichengreen. A Retrospective on the Bretton Woods System, Lessons for International Monetary Reform. Chicago: The University of Chicago Press.

Bordo, Michael, Ali Dib, and Lawrence Schembri. 2010. Canada’s Pioneering Experience with a Flexibel Exchange Rate in the 1950s: (Hard) Lessions Learned for Monetary Policy in a Small Open Economy,” International Journal of Central Banking, (September): 51 -99.

Bordo, Michael D. and Barry Eichengreen. 2008. “Bretton Woods And The Great Inflation” NBER Working Paper 14532, (December). 
Bordo, Michael D., Ronald MacDonald, and Michael J. Oliver. 2010. "Sterling in Crisis: 19641967” European Review of Economic History 13:(3): 437 - 459.

Bordo, Michael, Dominique Simard, and Eugene White. 1996. France and the Bretton Woods Monetary System: 1960 -1968. NBER Working Paper No. 4642 (May).

Bremner, Robert P. 2004. Chairman of the Fed: William McChesney Martin Jr. and the Creation of the Modern American Financial System, New Haven: Yale University Press.

Coombs, Charles A. 1976. The Arena of International Finance, John Wiley \& Sons: New York

Coombs, Charles A. 1971. "System Operations in Forward Marks.” unpublished memorandum, May 3, 1971.

Coombs, Charles A., M. Ikle, E. Ranalli, and J. Tungeler. “Conversation on International Finance,” Federal Reserve Bank of New York, Monthly Review, August 1963, pp. 11421.; cited in Bulletin September 1964, 1125.

Cairncross, Alec and Eichengreen, Barry 2003. Sterling in Decline: The Devaluations of 1931, 1949, and 1967. New York: Palgrave Macmillan

Federal Reserve Bank of New York, Annual Report on Operations in Foreign Currencies, unpublished report submitted by the Special Manager of the System Open Market Account for Foreign Currency Operations to the Federal Open Market Committee, various issues.

Federal Open Market Committee. Minutes of the Federal Open Market Committee, 10 January 1961- 16 March 1976. Board of Governors of the Federal Reserve System: Washington, D. C.

Federal Open Market Committee. (1962) "Scope and Character of Initial Foreign Currency Operations of the System" and "Proposed Short-Term Program for Coordinated Treasury and System Operations in Foreign Currencies.” Unpublished documents distributed to the FOMC by Messrs. Coombs and Young on February 6, 1962. Recorded in Records Section, February 12, 1962.

Gavin, Francis J. (2004) Gold, Dollars, and Power, the Politics of International Monetary Relations, 1958-1971. Chapel Hill: The University of North Carolina Press.

Hetzel, R.L. (1996) "Sterilized Foreign-Exchange Intervention: The Fed Debate in the 1960s," Federal Reserve Bank of Richmond, Economic Quarterly 82(2): 21-46.

Hetzel, Robert L. (2008) The Monetary Policy of the Federal Reserve, A History. Cambridge University Press: New York

Holland, Robert C. (1967) "Criteria for Increasing Membership in the Federal Reserve Network of Reciprocal Currency Arrangements.” Unpublished memorandum, 1 February 1967.

International Monetary Fund (1972) Annual Report of the Executive directors for the Fiscal Year Ended April 30, 1972, Washington, D.C.

James, Harold. 1996. International Monetary Cooperation Since Bretton Woods, New York: Oxford University Press. [HG 3881 .J33]

MacLaury, Bruce K. 1969. Discussion of Questions Raised by Governor Maisel Concerning System Foreign Currency Operations,” unpublished memorandum. 30 January 1969. 
Martin, William McC., Jr. (1961) "Federal Reserve Operations in Perspective," Federal Reserve Bulletin. Board of Governors of the Federal Reserve System Washington, D.C. (February 1961), pp. 272-281. Reprint of a statement before the Joint Economic Committee on March 7, 1961.

Meltzer, Allen H. 2009a. A History of the Federal Reserve, vol. II, book one, 1951-1969. University of Chicago Press: Chicago and London.

Meltzer, Allan H. (2005) Origins of the Great Inflation, Federal Reserve Bank of St. Louis Review (March/April, part 2): 145-175.

Meltzer, Allan H. (1991) “U.S. Policy in the Bretton Woods Era,” Federal Reserve Bank of St. Louis, Economic Review, May/June, pp. 54-83.

Pauls, B.D., (1990) “U.S. Exchange-Rate Policy: Bretton Woods to Present,” Federal Reserve Bulletin (November 1990) pp. 891-908.

Powell, James. A History of the Canadian Dollar, Canada: Bank of Canada, 2005. http://www.bankofcanada.ca/en/dollar_book/dollar_book.pdf.

Romer, Christina D. and Romer, David H. (2002) "The Evolution of Economic Understanding and Postwar Stabilization Policy," in Rethinking Stabilization Policy, A Symposium Sponsored by The Federal Reserve Bank of Kansas. Jackson Hole, Wyoming, August 29-31, 2002 [HB 3732 .R48]

Solomon, Robert. 1982. The International Monetary System, 1945-1981. New York: Harper \& Row Publishers. [HG 3881 .S5574 1982]

Solomon, Robert. 1971. "Use of Swap Network," unpublished memorandum (13 August).

Solomon, Robert. 28 March 1968. “The Two-Market System for Gold,” unpublished memorandum. Federal Reserve System.

Schwartz, Anna J. 1997. "From Obscurity to Notoriety: A Biography of the Exchange Stabilization Fun,” Journal of Money, Credit, and Banking, 29 (2): 135-153.

Task Force on System Foreign Currency Operations. 1990. "Legal Basis for Foreign-Exchange Operations.” Paper \#1 (31 January) unpublished.

Task Force on System Foreign Currency Operations. 1990. "Evolution of Formal Procedures for FOMC Oversight of System Foreign-Exchange Operations.” Paper \#2 (29 January) unpublished.

Task Force on System Foreign Currency Operations. 1990. "Federal Reserve-Treasury Coordination” Paper \#6 (18 January) unpublished.

Task Force on System Foreign Currency Operations. 1990. "Reciprocal Currency Arrangements (The “Swap” Network)” Paper \#9 (24 January 1990) unpublished.

Task Force on System Foreign Currency Operations. Profits and Losses in U.S. ForeignCurrency Operations, Paper \#10. 8 January 1990.

Todd, Walker F. (1992) "Disorderly Markets: The Law, History, and Economics of the Exchange Stabilization Fund and U.S. Foreign-Exchange Market Intervention,” in George G. Kaufman, ed., Research in Financial Services: Private and Public Policy, Vol. 4. Greenwich, Conn.: JAI Press Pp. 111-79 
Triffin, Robert. 1957. Europe and the Monetary Muddle, from Bilateralism to NearConvertibility, 1947-1956. Westport, Conn: Greenwood Press. [HG 924/ .T69]

Triffin, Robert. 1960. Gold and the Dollar Crisis, The Future of Convertibility. New Haven, Conn: Yale University Press. [HG 255 / T8]

U.S. Treasury (February 9, 1962). "Treasury Experience in the Foreign-Exchange Market,” transmitted by Robert H. Knight, Treasury General Counsel to Ralph A. Young, Adviser to the Board of Governors of the Federal Reserve System, (12 pages with 5 tables). Recorded in Records Section on February 12, 1962.

U.S. Treasury (February 6, 1962). "Treasury Memorandum on Treasury and Federal Reserve Foreign Currency Operations and Policies-Relationships and Coordination (As Amended to Meet Federal Reserve Suggestions) (draft copy, 6 pages). Recorded in Records Section on February 12, 1962.

Yeagar, Leland B. 1966. Internaitonal Monetary Relations, Theory, History, and Policy. Harper \& Row Publishers: New York. 


\section{Endnotes}

${ }^{1}$ For an overview of Bretton Woods see: Meltzer (1991), Bordo (1993), and James (1996). Previous discussions of U.S. intervention during the period include Coombs (1976), Pauls (1990), Todd (1992), and Hetzel (1996).

${ }^{2}$ Article VI of the IMF Articles of Agreement authorized restrictions on financial flows.

3 To construct the real price of gold, we deflate the official price using the nonseasonally adjusted consumer price index, 1982-84 $=100$.

4 All U.S. balance-of-payments data are from the U.S. Commerce Department as reported in the Economic Report of the President, 1969.

${ }^{5}$ Coombs (1976, p. 48) notes: "By the late fifties Washington officials were already dropping hints of government concern over the erosion of our gold stock, which further sensitized the qualms already felt by many European officials.”

${ }^{6}$ Triffin (1960) suggested creating a source of non-dollar international reserves through the IMF. The IMF first issues Special Drawing Rights in January 1970.

7 Unless otherwise indicated, data on gold in this section are from Board of Governors (1976) tables $14.1 \& 14.3$.

${ }^{8}$ These figures include a \$344 million payment (gold subscription) to the IMF in 1959.

${ }^{9}$ Until 1968, U.S. law mandated a $25 \%$ gold reserve requirement on outstanding notes and liabilities of the Federal Reserve Banks.

10 Chapter 5 discusses the Great Inflation in more detail.

11 Meltzer 1991, Hetzel 1996, and Pauls 1990 also discuss the issues raised in this section.

12 Hetzel (1996, p. 22) notes that most key European currencies were undervalued relative to the dollar.

${ }^{13}$ Budget deficit data are from the Economic Report of the President (2005), Table B-78, and include on-budget and off-budget balances.

${ }^{14}$ The data in this section appear in Bordo and Eichengreen (2008) appendix 2.

15 See the discussions of FOMC decisions in Bordo and Eichengreen (2008).

16 Eventually, policy makers referred to this program as "Operation Nudge" and later still as "Operation Twist."

17 Unless otherwise indicated, the information and data in this section about Treasury interventions come from: "Treasury Experience in the Foreign-Exchange Market," and is hereafter referred to as "U.S. Treasury, Experience" See References. See also Bulletin September 1962, pp. 1138-1153. 
${ }^{18}$ Congress established the Exchange Stabilization Fund under the Gold Reserve Act of 1934 for the purpose of foreign-exchange-market intervention. We discuss the ESF in chapter 2.

19 U.S. Treasury Experience, (1962, p. 721).

20 This statement, of course, ignores the cost of financing and covering the transactions.

21 Debt prepayments stemmed from negotiations between the Eisenhower administration and Germany over the cost of troop deployment.

${ }^{22}$ We report data from the Desk Report (1963, p. 7 and p. B-23), which differ from the Bulletin (September 1962, p. 1144).

23 The Treasury swaps were on an ad hoc basis. Unlike the Federal Reserve System, which we discuss below, the Treasury did not maintain formal reciprocal swap lines that reverted to a standby basis when not drawn down.

24 The analysis in this section draws on the Federal Open Market Committee Minutes of September 12, 1961 and December 19, 1961. See also Hetzel (1996), Todd (1992), and FOMC Task Force Paper \#1.

25 These data on the ESF are discussed in U.S. Treasury, Memorandum (1962, p. 2). U.S. Treasury, Experience (1962) also contains a table showing foreign currency holdings.

${ }^{26}$ Whether the impetus for the Federal Reserve's participation in U.S. foreign-exchange operations originated with the Treasury or with the Federal Reserve System is not entirely clear. The Treasury's website suggests that the Treasury “invited” the Federal Reserve to participate in the interventions in 1962, and this is the conventional view (see www.ustreas.gov/offices/international-affairs/esf/history). The FOMC, Minutes, (January 9, 1962, p. 66-67), however, seem to suggest that the Federal Reserve System considered foreignexchange intervention on its own initiative. Coombs (1976 p. 71) suggests that Chairman Martin wanted to intervene.

27 Todd (1992, pp. 134 -135) argues that Hackley set out to interpret the Federal Reserve Act in a way that would support intervention, rather than to provide an objective interpretation of the statute.

28 Although open-market operations, including foreign-exchange interventions, fell under the purview of the FOMC, these associated activities fell under the Board of Governor's jurisdiction.

29 In 1920s and 1930s, however, the Federal Reserve Bank of New York was providing stabilization funds to foreign central banks; it was not directly defending the dollar's exchange value.

30 Warehousing refers to a swap transaction between the Federal Reserve System and the U.S. Treasury in which the Treasury sells foreign currency to the System for dollars spot and buys it back forward at a specific rate and settlement date. See chapter 5 on warehousing.

31 Hackley (1962, 19 - 20), however, did not believe that the Federal Reserve could deal directly with the IMF in any way other than in its capacity as an agent of the Treasury.

32 Why the Treasury did not seek to increase the ESF's appropriation is unclear. The Treasury may have feared that Congress would only increase the ESF's appropriation if the Treasury 
would agree to some type of Congressional oversight. The ESF is unusual in that only the president and the secretary of the treasury can review its actions (see Schwarz, 1997).

33 A copy of this letter is found in Task Force \#2, 1990, appendix A.

34 Robert H. Knight, General Counsel of the Treasury, had warned Hackley that the System should move forward without legislation in part because "there was a range of ideas on the Hill with regard to the Federal Reserve System, including varying views with respect to the operation and organization of the System. Legislation, if sought, might become a vehicle for adding various amendments the nature of which could not be foretold.” See FOMC Minutes, 9 January 1962, p. 61.

35 Governor Robertson expressed the reasons for his dissent at the 5 December 1961 FOMC meeting. See FOMC Minutes, 5 December 1962, pp. 57-62. See also Task Force \#2, pp. 3-4.

36 In 1982, with the onset of developing-country-debt problems, some members of Congress expressed concern that the Fed might use its authority to invest in foreign securities as a means of providing financial assistance to debtor countries (FOMC Task Force \#1, pp. 23-24)

37 This section is based on the discussion that appears in the FOMC Minutes 13 February 1962, pp. 82 - 95. See also Bulletin September 1962, pp. 1150 - 1153, and Task Force Paper \#2, 1990.

38 It is not clear when or how the System obtained these accounts.

39 The Treasury also has maintained swap lines, but typically on an ad hoc basis. With the exception of a Mexican swap line, Treasury swaps were not reciprocal. Often the Treasury established swap with developing countries to provide those countries with temporary loans. The Treasury’s first swap line was with Mexico in 1936.

40 Moreover, the liquidity that swap drawings provided did not add to the U.S. balance-ofpayments deficit.

41 The System sometimes undertook "third party swaps" in which it would swap one foreign currency for another. These were typically used to pay down an outstanding balance on swap line.

42 In the late 1970s, as discussed in chapter 5, conditionality with respect to swap drawings became a problem and encouraged the United States to accumulate a large portfolio of foreign exchange.

43 “All this may seem to be an excessively roundabout way for the Federal to borrow foreign currencies. But apparently when the Federal Reserve Act was drafted, no one had contemplated such a need, and no explicit statutory provision for such borrowing was made. The swap technique, on the other hand, was clearly authorized and yielded precisely the same results as a direct borrowing from a foreign central bank.” (Coombs 1976, p.77)

44 Coombs (1976, p. 75-76) reprints the original swap agreement with the Bank of France.

45 The European central banks include those of Austria, Belgium, England, France, Germany, Italy, the Netherlands, and Switzerland.

46 In 1967, the FOMC did not accept a proposal to extend a swap line the Venezuela because that country did not meet IMF Article VIII requirements (FOMC Minutes 4 April 4, 1967, p. 10- 
13; Holland, 28 February 1967). In 1969, the FOMC did not accept a proposal to extend a swap line to Ireland because of its relatively small size (Reynolds 16 December 1969).

47 See the previous discussion of the "Guidelines For System Foreign Currency Operations.”

48 The data in this paragraph come from Solomon 13 August 1971, pp. 3-4. We do not have comparable data for the entire 1962 through 1971 period.

49 For background see Bordo and Schembri( 2004) and Yeager (1966).

50 Much of the information in this section is from MacLaury (30 January 1969) and pertains to operations prior to 1968. We have no information on such operations after 1968.

51 Although U.S. monetary authorities did not undertake very many spot market transactions with the objective of affecting the exchange rate, they frequently made spot market purchase and sales of foreign exchange in conjunction with other activities. They might, for example, buy foreign currency in the spot market to repay a swap or to meet forward exchange commitments.

52 Actually, the Bundesbank sold marks against dollars in Germany and the System "took over" the Bundesbank transactions.

53 At this time the Netherlands bank, which maintained a fairly rigid limit on dollar accumulation, was also selling dollars spot into the market, so these transaction amounted to a market swap with the dollars reverting to the United States.

54 The Treasury undertook similar transactions in 1962 or 1963.

55 The G10 were: Belgium, Canada, France, Germany, Italy, Japan, the Netherlands, the United Kingdom, the United States, Sweden. Switzerland joined the GAB in 1964.

56 Modern warehousing involves a spot purchase of foreign exchange from the Treasury coupled with a forward sale back to the Treasury. Chapter 5 discusses warehousing.

57 The narrative in this section draws on the Bulletin 1963-1968.

58 In fact, the U.K. pound experienced several crises between 1945 and 1962. Bordo et. al. (2010) offers a brief discussion and references.

59 In early January 1963, the Federal Reserve drew \$25 million equivalent British pounds from its swap line with the Bank of England and sold \$5.6 million equivalent of this drawing to support the dollar.

60 The System used its holdings of sterling to obtain other currencies during the year. On 31 March 1964, the System sold \$10 million equivalent sterling to the U.S. Treasury, which used these fund to acquire Swiss francs through a sterling-Swiss franc swap with the BIS. In September and December, both the System and the U.S. Treasury swapped sterling for Dutch guilder. System and Treasury swaps of sterling for Swiss francs were reversed in December.

61 The banks lent dollar reserves.

62 See chapter 5 for a discussion of intervention tactics.

63 As discussed below, France would not participate in a scheme that it equated with maintaining the reserve status of a specific currency, but offer a general line of credit to the United Kingdom (Coombs 1976, p. 134). 
64 After some cantankerous negotiation, other central banks reluctantly agreed to $\$ 400$ million in credits (Coombs 1976, p. 143).

65 Estimates of the gold points appear in the Desk Report (1964) and. Coombs (1976, p. 47).

66 On the collapse of the Gold Pool see also: Coombs 1976, pp. 152-173.

67 “...Mr. Coombs said that the swap line with the French was useless. The only purpose in continuing the swap line was to symbolize some continuing link between the Bank of France and the Federal Reserve, and to avoid an overt disruption of relationships which might lead to market disturbances.” (FOMC Minutes 23 August 1966, p. 21).

68 The Netherlands Bank also sold \$30 million in gold to the U.S. Treasury (FOMC Minutes, 8 June 1968, p. 3).

69 The controls actually required French banks to break outstanding forward contracts with their customers and turn over to the Bank of France the spot foreign exchange held as cover for those contracts.

70 The Bank of France also repaid $\$ 45$ million of its swap debt in February and $\$ 12$ million in March.

71 The Treasury swapped nearly its entire mark portfolio for Swiss francs during the Cuban missile crisis.

72 See Coombs, et al. 1963, pp. 114-21.

73 In 1968, the Treasury issued $\$ 625$ million equivalent mark-denominated securities to the Bundesbank as part of an agreement reached with the German government in 1967 and renewed in 1968 to neutralize the costs of U.S. troops stationed in Germany. In the year, the Treasury redeemed a \$50 million mark-denominated security held by the Bundesbank. In addition, the Treasury issued \$125 million equivalent medium-term securities to German banks as part of the 1968 agreement. The total U.S. Treasury, mark-denominated securities increased $\$ 700$ million in 1968 to $\$ 1.3$ billion.

74 In October, the U.S. Treasury bought a modest amount of marks to meet coming forward commitments.

75 The possibility of an imminent mark revaluation left the Treasury, with outstanding forward commitments to sell marks, exposed. On November 18, the System sold the Treasury \$52.3 million to provide partial cover.

76 At their Bonn meeting on November 20, 1968, the G10 countries recommended that Germany revalue the mark.

77 The narrative in this section draws on the Bulletin 1963-1968.

78 Following the closing of the U.S. gold window, the French foreign exchange market closed until August 23, when it re-opened on a two-tier basis. The Bank of France would defend an official rate for trade and related transactions. All other transaction would occur at a floating market rate. Pressure continued on the official rate, and French reserves increased \$1.1 billion in August 1971. 
79 Canada allowed the dollar to float from September 1950 to 3 May 1960; see Bordo, et al. (2010).

80 Germany’s experience was far from unique. Other countries, including Belgium, France, Japan, the Netherlands, and the United Kingdom had similar experiences with reserve accumulations.

81 At the end of January 1973, the System held only $\$ 67.4$ million equivalent marks in its portfolio. It financed most of the February sales through the direct acquisitions of marks from a central bank. The System also drew on its swap lines, but repaid the drawing within the month.

82 In July 1973, most of the swap lines were increased to allow for renewed U.S. foreign exchange interventions, see chapter 5. At this time the line with the Swiss National Bank increased from $\$ 1.0$ billion to $\$ 1.4$ billion and the Swiss franc line with the BIS rose from $\$ 1.0$ billion to $\$ 1.25$ billion. 